\title{
Metal-free, rapid, and highly chemoselective reduction of aromatic nitro compounds at room temperature
}

\author{
Mingyeong Jang, $\uparrow$ Taeho Lim, $\uparrow$ Byoung Yong Park $\uparrow$ and Min Su Han* \\ Department of Chemistry, Gwangju Institute of Science and Technology (GIST), 123 \\ Cheomdangwagi-ro, Buk-gu, Gwangju 61005, Republic of Korea \\ * E-mail: happyhan@gist.ac.kr \\ $\uparrow$ Mingyeong Jang, Taeho Lim and Byoung Yong Park contributed equally to this work.
}

\section{Table of Contents}

1. Optimization of the reaction conditions for the reduction of 3-nitrosyrene

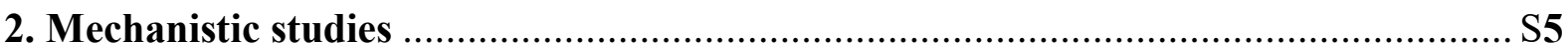

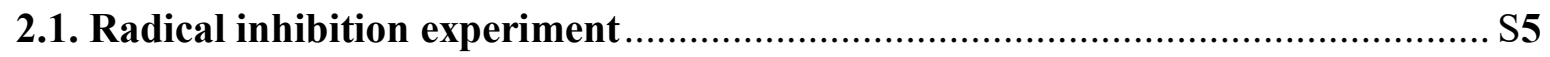

2.1.1. Control experiment for the stability of $\mathrm{B}_{2}(\mathrm{OH})_{4}$ with radical inhibitor............ S5

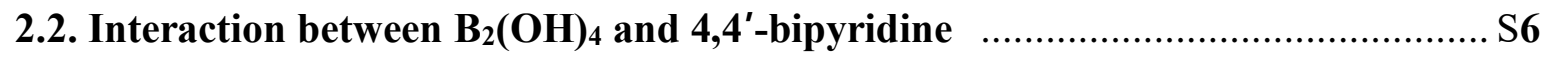

3. Optimization of reaction conditions for one-pot nitro group reduction and $\mathrm{N}$ formylation following nitro reduction S7

4. Spectral copies of ${ }^{1} \mathrm{H},{ }^{13} \mathrm{C}$ NMR of the products S8 


\section{Optimization of the reaction conditions for the reduction of 3-nitrosyrene}

Table S1. Screening of Lewis bases for the reduction of 3-nitrostyrene (1a). ${ }^{\text {a }}$<smiles>C=Cc1cccc([N+](=O)[O-])c1</smiles>

$1 \mathrm{a}$

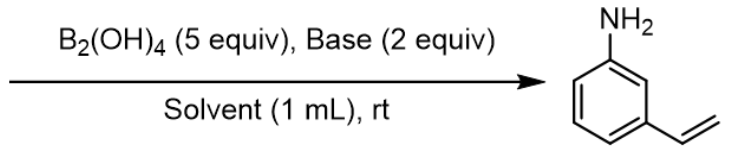

2a

\begin{tabular}{|c|c|c|c|c|c|}
\hline Entry & Base & Solvent & Time & Conversion $(\%)^{\mathrm{b}}$ & Yield $(\%)^{\mathrm{b}}$ \\
\hline 1 & $\mathrm{KO} t \mathrm{Bu}$ & $\mathrm{EtOH}$ & $4 \mathrm{~h}$ & 68 & 44 \\
\hline 2 & $\mathrm{~K}_{3} \mathrm{PO}_{4}$ & $\mathrm{EtOH}$ & $4 \mathrm{~h}$ & 70 & 47 \\
\hline 3 & $\mathrm{NaOMe}$ & $\mathrm{EtOH}$ & $4 \mathrm{~h}$ & 56 & 23 \\
\hline 4 & KOAc & $\mathrm{EtOH}$ & $4 \mathrm{~h}$ & 33 & 12 \\
\hline 5 & $\mathrm{NaOH}$ & $\mathrm{EtOH}$ & $4 \mathrm{~h}$ & 55 & 24 \\
\hline 6 & $\mathrm{KO} t \mathrm{Bu}$ & $\mathrm{MeOH}$ & $3 \mathrm{~h}$ & 96 & 37 \\
\hline 7 & $\mathrm{~K}_{3} \mathrm{PO}_{4}$ & $\mathrm{MeOH}$ & $3 \mathrm{~h}$ & 85 & 46 \\
\hline 8 & $\mathrm{NaOMe}$ & $\mathrm{MeOH}$ & $3 \mathrm{~h}$ & 79 & 41 \\
\hline 9 & KOAc & $\mathrm{MeOH}$ & $3 \mathrm{~h}$ & 71 & 41 \\
\hline 10 & $\mathrm{~K}_{2} \mathrm{CO}_{3}$ & $\mathrm{MeOH}$ & $3 \mathrm{~h}$ & 88 & 50 \\
\hline 11 & $\mathrm{KO} t \mathrm{Bu}$ & DMSO & $3 \mathrm{~h}$ & $>99$ & 14 \\
\hline 12 & $\mathrm{~K}_{3} \mathrm{PO}_{4}$ & DMSO & $3 \mathrm{~h}$ & $>99$ & 17 \\
\hline 13 & $\mathrm{NaOMe}$ & DMSO & $3 \mathrm{~h}$ & $>99$ & 46 \\
\hline 14 & KOAc & DMSO & $3 \mathrm{~h}$ & $>99$ & 37 \\
\hline 15 & $\mathrm{~K}_{2} \mathrm{CO}_{3}$ & DMSO & $3 \mathrm{~h}$ & 99 & 35 \\
\hline 16 & DIPEA & DMSO & $3 \mathrm{~h}$ & $>99$ & 43 \\
\hline 17 & TEA & DMSO & $3 \mathrm{~h}$ & $>99$ & 62 \\
\hline 18 & Piperidine & DMSO & $3 \mathrm{~h}$ & 98 & 54 \\
\hline 19 & Pyridine & DMSO & $3 \mathrm{~h}$ & 75 & 64 \\
\hline 20 & Imidazole & DMSO & $3 \mathrm{~h}$ & 99 & 89 \\
\hline 21 & Morpholine & DMSO & $3 \mathrm{~h}$ & 82 & 42 \\
\hline 22 & Diphenylamine & DMSO & $3 \mathrm{~h}$ & 29 & 20 \\
\hline 23 & Quinoline & DMSO & $3 \mathrm{~h}$ & $>99$ & 66 \\
\hline 24 & Phenanthroline & DMSO & $3 \mathrm{~h}$ & $>99$ & 69 \\
\hline 25 & 2,2'-Bipyridine & DMSO & $3 \mathrm{~h}$ & $>99$ & 88 \\
\hline
\end{tabular}


Table S2. Screening of organocatalysts for the reduction of 3-nitrostyrene (1a).<smiles>C=Cc1cccc([N+](=O)[O-])c1</smiles>

1a

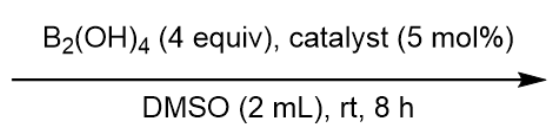

DMSO (2 mL), rt, $8 \mathrm{~h}$

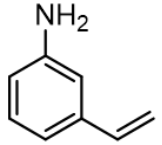

2a

\begin{tabular}{|c|c|c|c|}
\hline Entry & Catalyst & Conversion $(\%)^{\mathrm{b}}$ & Yield $(\%)^{\mathrm{b}}$ \\
\hline 1 & 2,2'-Bipyridine & 99 & 87 \\
\hline 2 & 4,4'-Bipyridine & $>99$ & 92 \\
\hline 3 & 2,2'-Biimidazole & 20 & 10 \\
\hline 4 & TMEDA & 33 & 25 \\
\hline 5 & 4-Dimethylaminopyridine & 54 & 40 \\
\hline 6 & Pyrazine & 44 & 31 \\
\hline 7 & 1,2,3-Triazole & 22 & 13 \\
\hline 8 & 1,2,4-Triazole & 34 & 25 \\
\hline 9 & 3-Amino-1,2,4-triazole & 50 & 35 \\
\hline 10 & Tetrazole & 36 & 22 \\
\hline 11 & 8-Hydroxyquinoline & 79 & 51 \\
\hline 12 & 4-Dimethylaminopyridine N-Oxide & 50 & 39 \\
\hline
\end{tabular}

'a Reaction conditions: $0.3 \mathrm{mmol}$ of $1 \mathrm{a}, \mathrm{B}_{2}(\mathrm{OH})_{4}(1.2 \mathrm{mmol})$, catalyst $(5.0 \mathrm{~mol} \%)$, and DMSO $(2 \mathrm{~mL})$ at room temperature for $8 \mathrm{~h}$. ${ }^{\mathrm{b}}$ Determined by ${ }^{1} \mathrm{H}$ NMR using $1,3,5-$ trimethoxybenzene as an internal standard.

Table S3. Control experiments in the presence and absence of catalyst 4,4'-bipyridine ${ }^{\text {a }}$

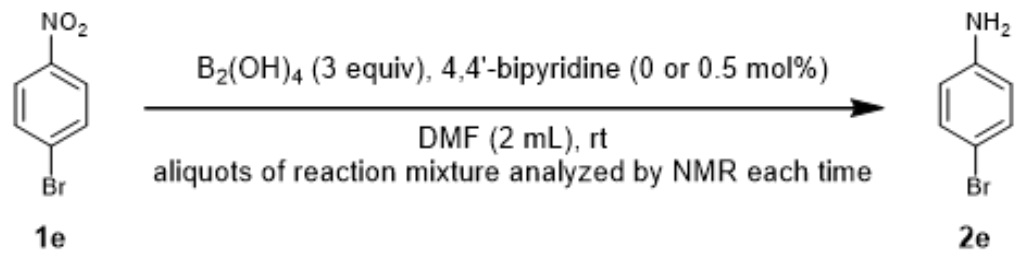

\begin{tabular}{ccc}
\hline $\begin{array}{c}\text { Reaction } \\
\text { time }\end{array}$ & NMR yield of $2 \mathbf{e}$ without catalyst & NMR yield of $\mathbf{2 e}$ with catalyst \\
\hline $1 \mathrm{~min}$ & $0 \%$ & $91 \%$ \\
$5 \mathrm{~min}$ & $3 \%$ & $96 \%$ \\
$10 \mathrm{~min}$ & $2 \%$ & $97 \%$ \\
$1 \mathrm{~h}$ & $4 \%$ & $96 \%$ \\
$3 \mathrm{~h}$ & $23 \%$ & $98 \%$ \\
$5 \mathrm{~h}$ & $34 \%$ & $98 \%$
\end{tabular}




$\begin{array}{lll}12 \mathrm{~h} & 50 \% & 97 \% \\ 24 \mathrm{~h} & 65 \% & 96 \%\end{array}$

aa Reaction conditions: $0.3 \mathrm{mmol}$ of $\mathbf{1 e}, \mathrm{B}_{2}(\mathrm{OH})_{4}(0.9 \mathrm{mmol})$, catalyst $(0$ or $0.5 \mathrm{~mol} \%)$, and DMF $(2 \mathrm{~mL})$ at room temperature. Determined by ${ }^{1} \mathrm{H}$ NMR using $1,3,5-$ trimethoxybenzene as an internal standard.

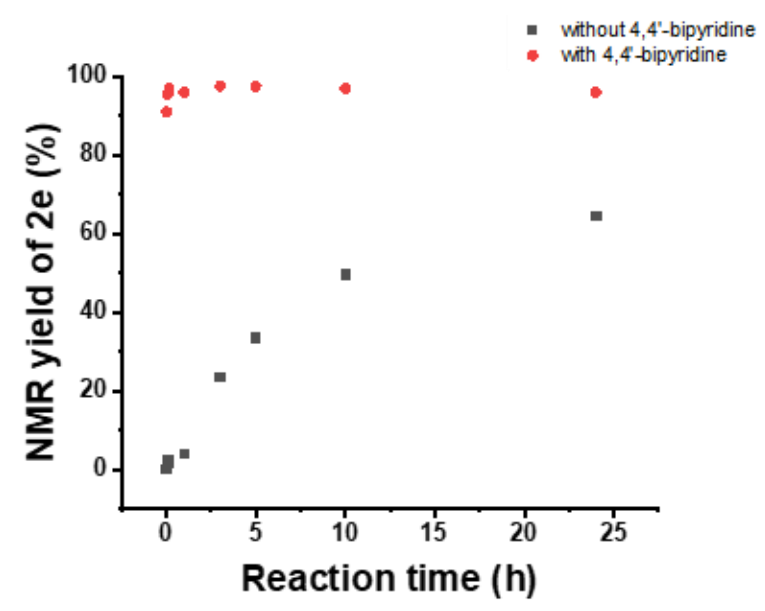

Figure S1. Time based NMR yield of $\mathbf{2 e}$ in the presence (red) and absence (black) of catalyst (4,4'-bipyridine).

Table S4. Screening of boron compounds for the reduction of 3-nitrostyrene (1a). ${ }^{\text {a }}$<smiles>C=Cc1cccc([N+](=O)[O-])c1</smiles>

$1 \mathrm{a}$

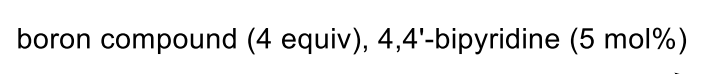

DMF, rt, $10 \mathrm{~min}$

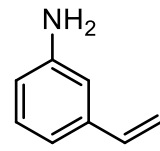

2a

\begin{tabular}{cccc}
\hline Entry & Boron compound & Conversion $(\%)^{\mathrm{b}}$ & Yield $(\%)^{\mathrm{b}}$ \\
\hline 1 & Tetrahydroxydiboron $\left(\mathrm{B}_{2}(\mathrm{OH})_{4}\right)$ & $>99$ & 97 \\
2 & Bis(neopentyl glycolato $)$ diboron $\left(\mathrm{B}_{2} \mathrm{nep}_{2}\right)$ & 5 & 2 \\
3 & Bis $($ pinacolato $)$ diboron $\left(\mathrm{B}_{2} \mathrm{pin}_{2}\right)$ & 0 & 0 \\
4 & Bis $($ catecholato $)$ diboron $\left(\mathrm{B}_{2} \mathrm{cat}_{2}\right)$ & 99 & 73 \\
5 & Pinacolborane $(\mathrm{HBpin})$ & 4 & 1
\end{tabular}

'Reaction conditions: $0.3 \mathrm{mmol}$ of $1 \mathrm{a}$, boron compound (1.2 mmol), 4,4'-bipyridine (5 mol\%), and DMF ( $2 \mathrm{~mL})$, at room temperature for $10 \mathrm{~min}$. ${ }^{\mathrm{b}}$ Determined by ${ }^{1} \mathrm{H}$ NMR using $1,3,5-$ trimethoxybenzene as an internal standard. 


\section{Mechanistic studies}

\subsection{Radical inhibition experiment}

Table S5. The effect of radical inhibitors. ${ }^{\mathrm{a}}$

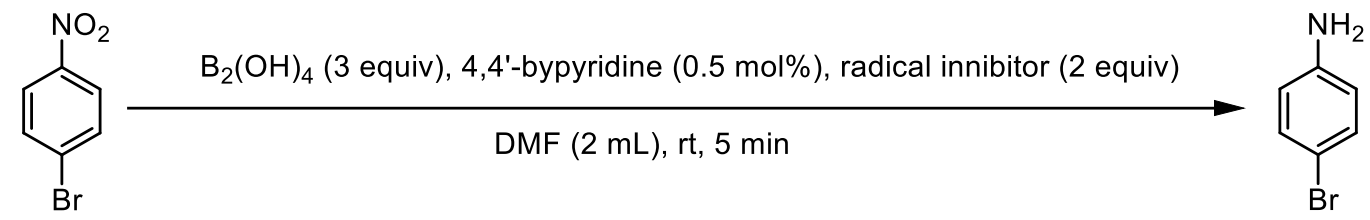

\begin{tabular}{|c|c|}
\hline Radical inhibitor & 4-Bromoanilne yield $(\%)^{\mathrm{b}}$ \\
\hline 2,6-Di-tert-butyl-4-methylphenol (BHT) & 91 \\
\hline Hydroquinone & 98 \\
\hline (2,2,6,6-Tetramethylpiperidin-1-yl)oxyl (TEMPO) & 12 \\
\hline \multicolumn{2}{|c|}{$\begin{array}{l}{ }^{\mathrm{a}} \text { Reaction conditions: } 4 \text {-Bromonitrobenzene }(0.3 \mathrm{mmol}), \mathrm{B}_{2}(\mathrm{OH})_{4}(0.9 \mathrm{mmol}), 4,4 \text {-bypyridine } \\
(0.5 \mathrm{~mol} \%) \text {, radical inhibitor ( } 2 \text { equiv), and } \mathrm{DMF}(2 \mathrm{~mL}) \text { at room temperature for } 5 \text { min. } \\
{ }^{\mathrm{b}} \text { Yields were determined by }{ }^{1} \mathrm{H} \text { NMR analysis using } 1,3,5 \text {-trimethoxybenzene as an internal } \\
\text { standard. }\end{array}$} \\
\hline
\end{tabular}

\subsubsection{Control experiment for the stability of $\mathrm{B}_{2}(\mathrm{OH})_{4}$ with radical inhibitor}

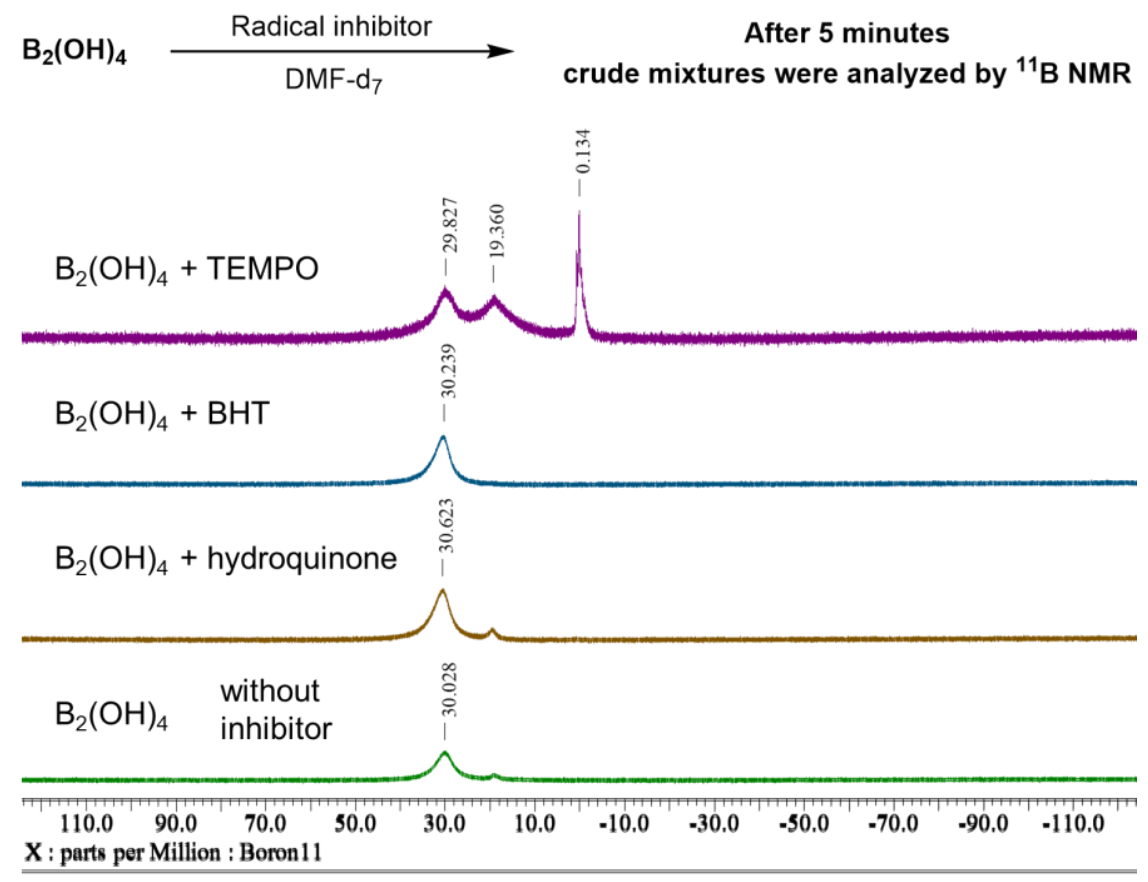

Figure S2. ${ }^{11} \mathrm{~B}$ NMR spectra analyzed from sample including radical inhibitor $(0.3 \mathrm{mmol}), \mathrm{B}_{2}(\mathrm{OH})_{4}(0.45 \mathrm{mmol}$, $0.0403 \mathrm{~g})$, and DMF- $d_{7}(2 \mathrm{~mL})$. 
Control experiment showed that the $\mathrm{B}_{2}(\mathrm{OH})_{4}$ was decomposed rapidly in the presence of TEMPO.

\subsection{Interaction between $\mathrm{B}_{2}(\mathrm{OH})_{4}$ and $4,4^{\prime}$-bipyridine}

Interaction between $\mathrm{B}_{2}(\mathrm{OH})_{4}$ and 4,4'-bipyridine was identified by adding stoichiometric amount 4,4'-bipyridine $(0.1 \mathrm{mmol})$ to the solution of DMF $(2 \mathrm{~mL})$ containing $\mathrm{B}_{2}(\mathrm{OH})_{4}(0.1 \mathrm{mmol})$. As shown in Figure $\mathbf{S 3}$, as soon as 4,4'-bipyridine was added to the transparent solution of $\mathrm{B}_{2}(\mathrm{OH})_{4}$, the solution turned to dark purple. As time passed, the solution turned to blue then yellow within 10 minutes. When 4-bromonitrobenzene $(0.03 \mathrm{mmol})$ was added to each of the purple and yellow solutions, only the purple solution was capable of reducing the nitro functional to the corresponding amine.

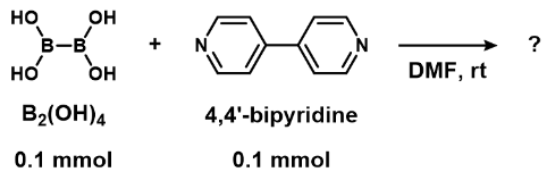

\section{4,4'-bipyridine}

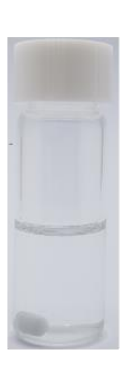

addition
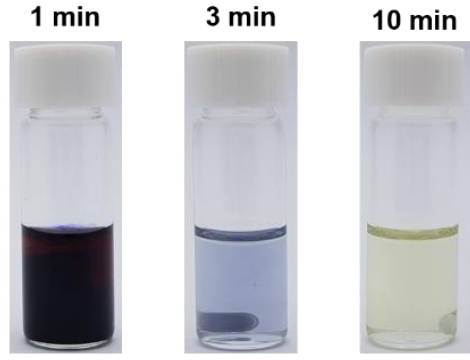

$\mathrm{B}_{2}(\mathrm{OH})_{4}$ solution in DMF

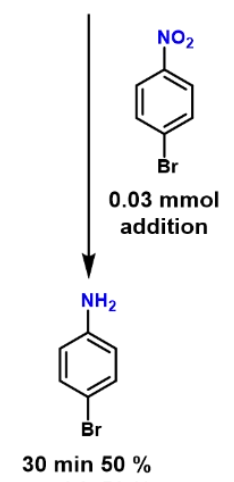

6 h $50 \%$
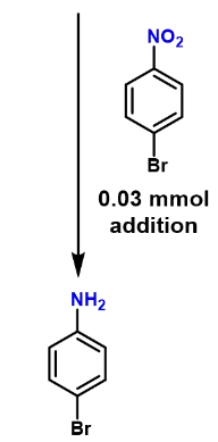

$30 \min 0 \%$
6 h $0 \%$

Figure S3. Interaction between $\mathrm{B}_{2}(\mathrm{OH})_{4}$ and 4,4'-bipyridine and reactivity to nitro reduction over time. 


\section{Optimization of reaction conditions for one-pot nitro group reduction and $\mathrm{N}$ -}

formylation following nitro reduction.

Table S6. Screening of reaction conditions for N-formylation of 4-nitrotoluene (1ag). ${ }^{\text {a }}$

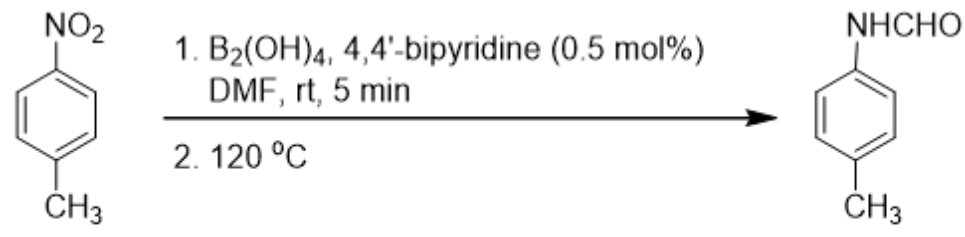

1ag 3ag

\begin{tabular}{|c|c|c|c|c|}
\hline Entry & $\mathrm{B}_{2}(\mathrm{OH})_{4}$ (equiv) & Solvent & Time & Yield $(\%)^{\mathrm{b}}$ \\
\hline 1 & 4 & DMF (2 mL) & $24 \mathrm{~h}$ & 61 \\
\hline 2 & 4 & DMF (2 mL) & $48 \mathrm{~h}$ & 64 \\
\hline 3 & 4 & DMF (3 mL) & $24 \mathrm{~h}$ & 38 \\
\hline 4 & 4 & DMF (4 mL) & $24 \mathrm{~h}$ & 49 \\
\hline 5 & 3 & DMF (2 mL) & $24 \mathrm{~h}$ & 83 \\
\hline $6^{\mathrm{c}}$ & 3 & DMF (2 mL) & $24 \mathrm{~h}$ & 90 \\
\hline 7 & 3 & dry DMF (2 mL) & $24 \mathrm{~h}$ & 77 \\
\hline
\end{tabular}


4. Spectral copies of ${ }^{1} \mathrm{H},{ }^{13} \mathrm{C}$ NMR of the products

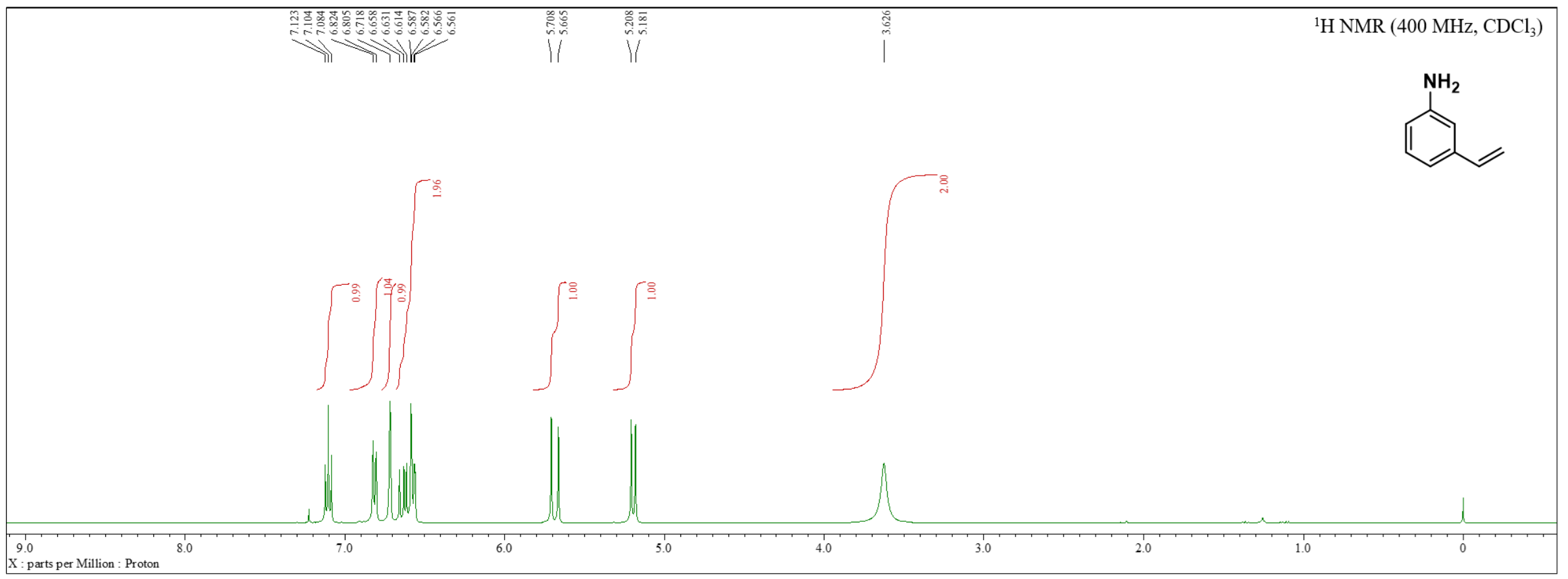

Figure S4. ${ }^{1} \mathrm{H}$ NMR of $\mathbf{2 a}$ in $\mathrm{CDCl}_{3}$. 


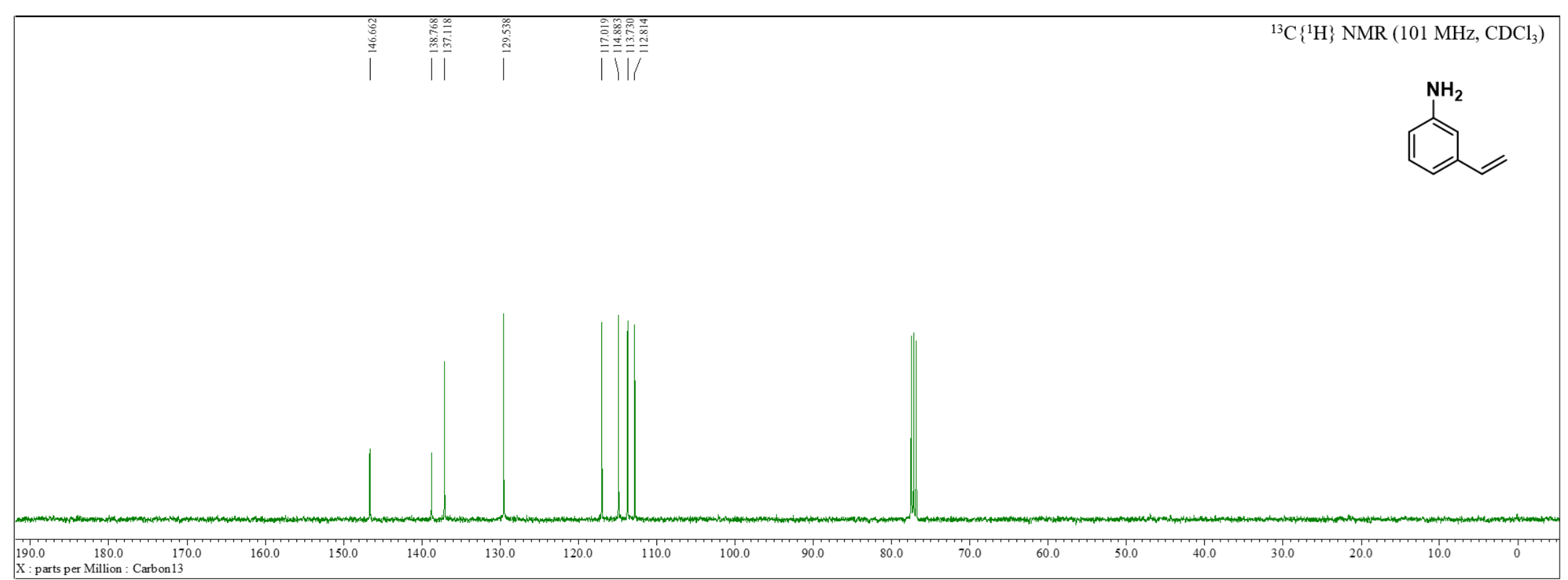

Figure S5. ${ }^{13} \mathrm{C}\left\{{ }^{1} \mathrm{H}\right\} \mathrm{NMR}$ of $\mathbf{2 a}$ in $\mathrm{CDCl}_{3}$ 


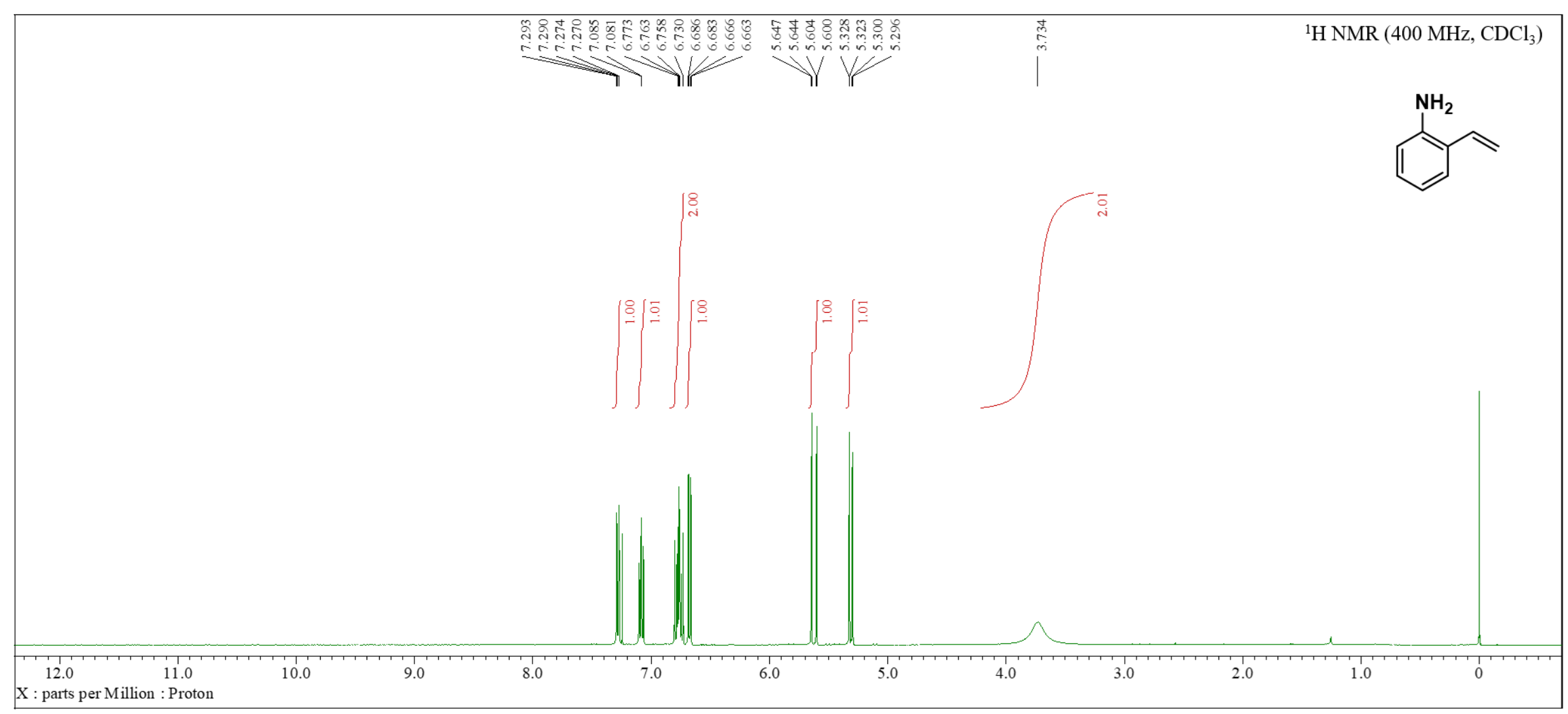

Figure S6. ${ }^{1} \mathrm{H}$ NMR of $\mathbf{2 b}$ in $\mathrm{CDCl}_{3}$. 


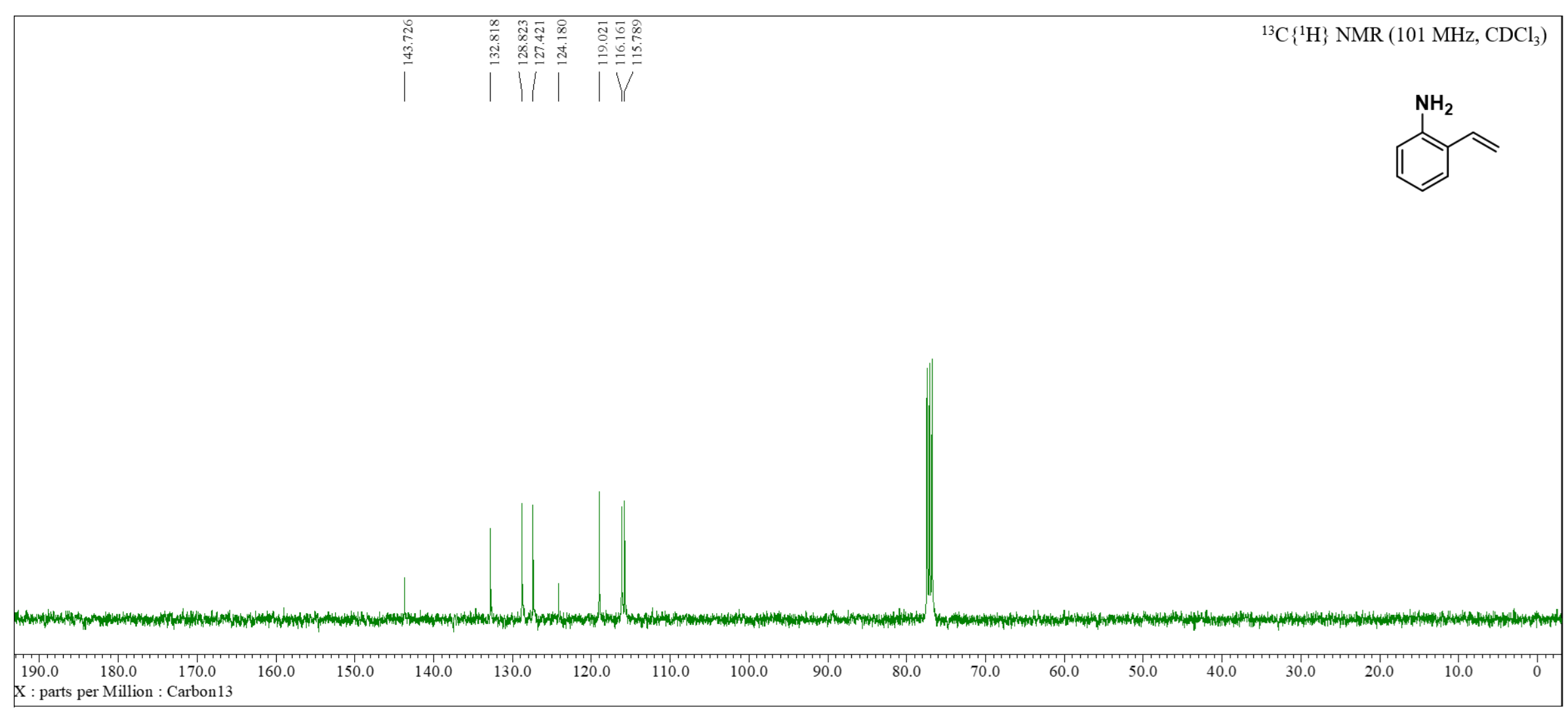

Figure S7. ${ }^{13} \mathrm{C}\left\{{ }^{1} \mathrm{H}\right\}$ NMR of $\mathbf{2 b}$ in $\mathrm{CDCl}_{3}$. 


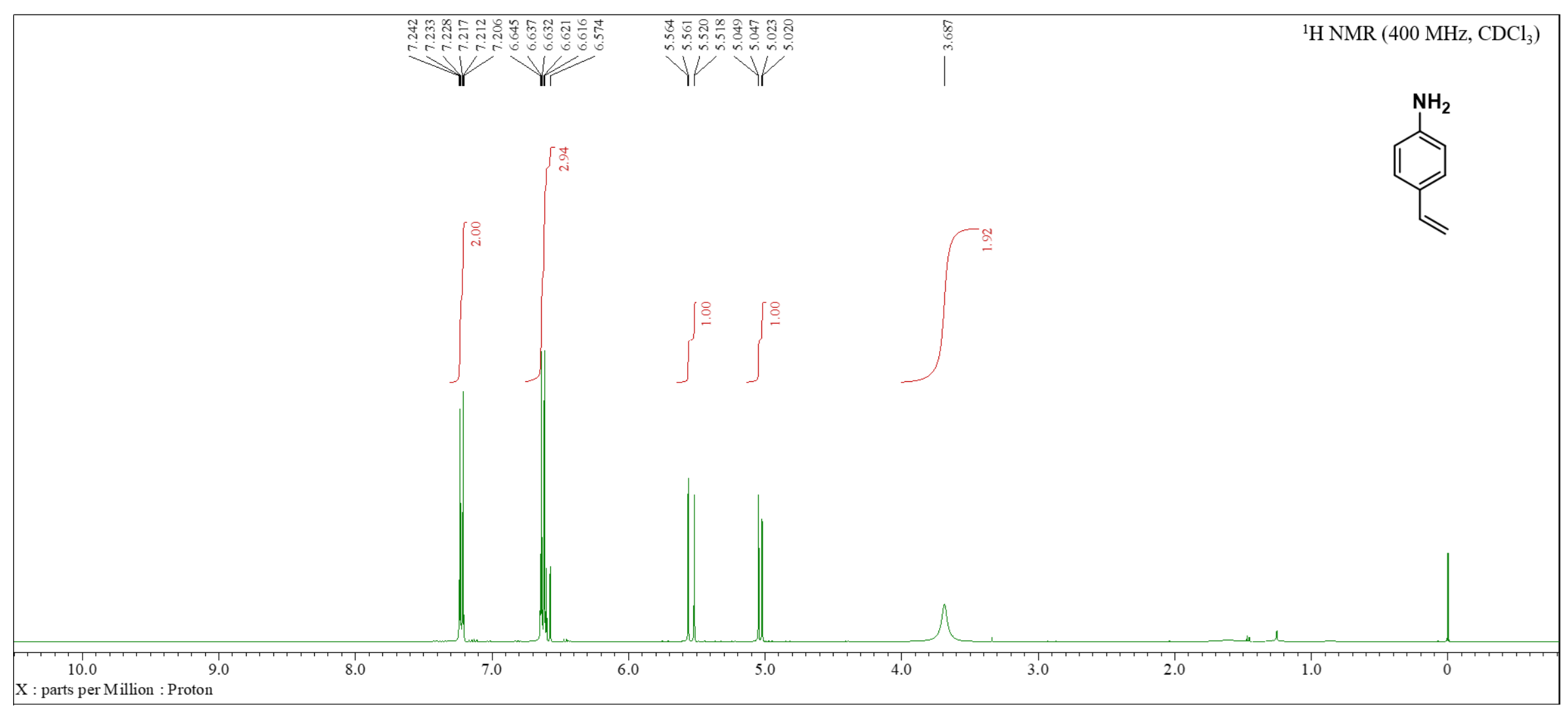

Figure S8. ${ }^{1} \mathrm{H}$ NMR of $2 \mathrm{c}$ in $\mathrm{CDCl}_{3}$ 


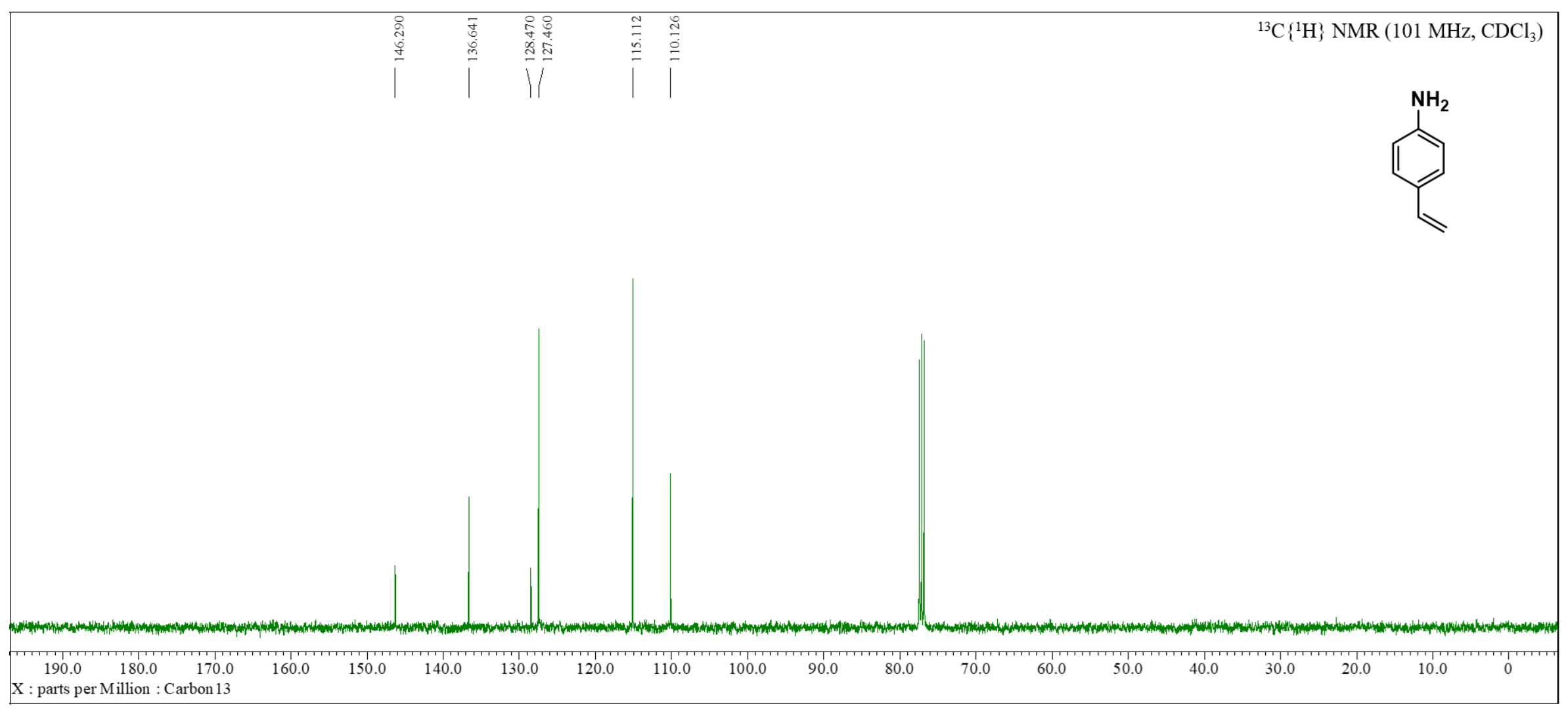

Figure S9. ${ }^{13} \mathrm{C}\left\{{ }^{1} \mathrm{H}\right\}$ NMR of $\mathbf{2 c}$ in $\mathrm{CDCl}_{3}$ 


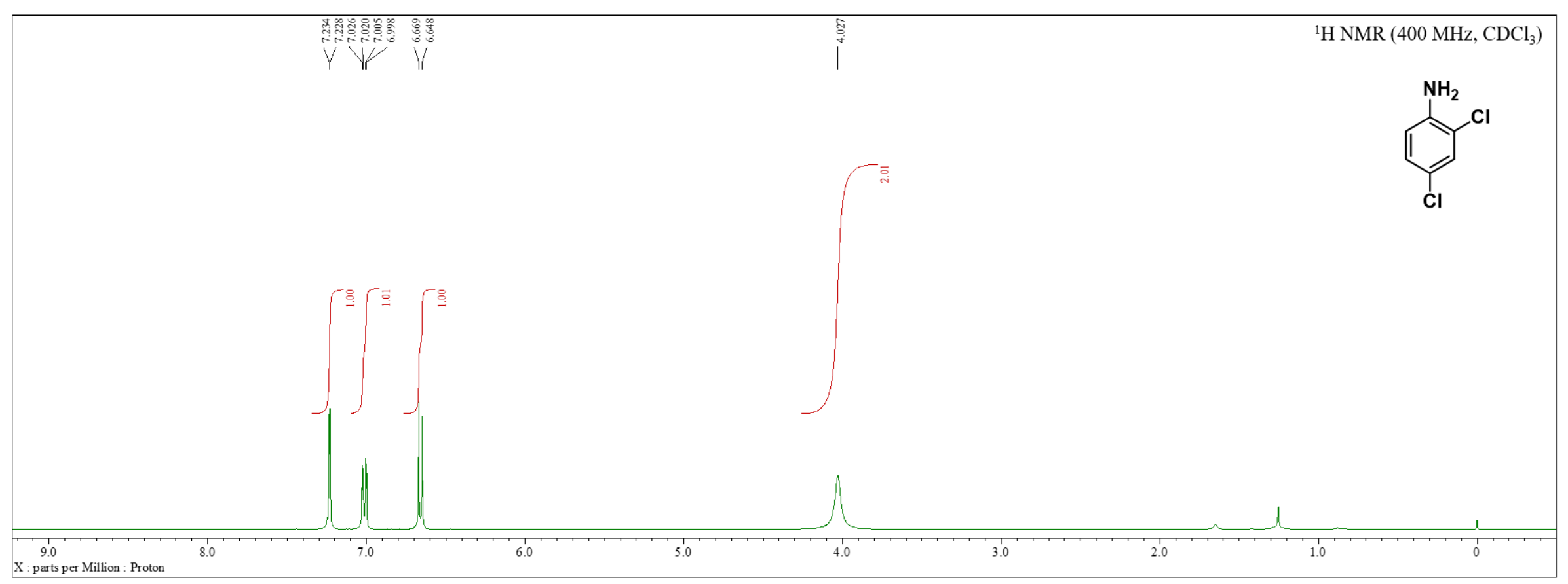

Figure S10. ${ }^{1} \mathrm{H} \mathrm{NMR}$ of $\mathbf{2 d}$ in $\mathrm{CDCl}_{3}$ 


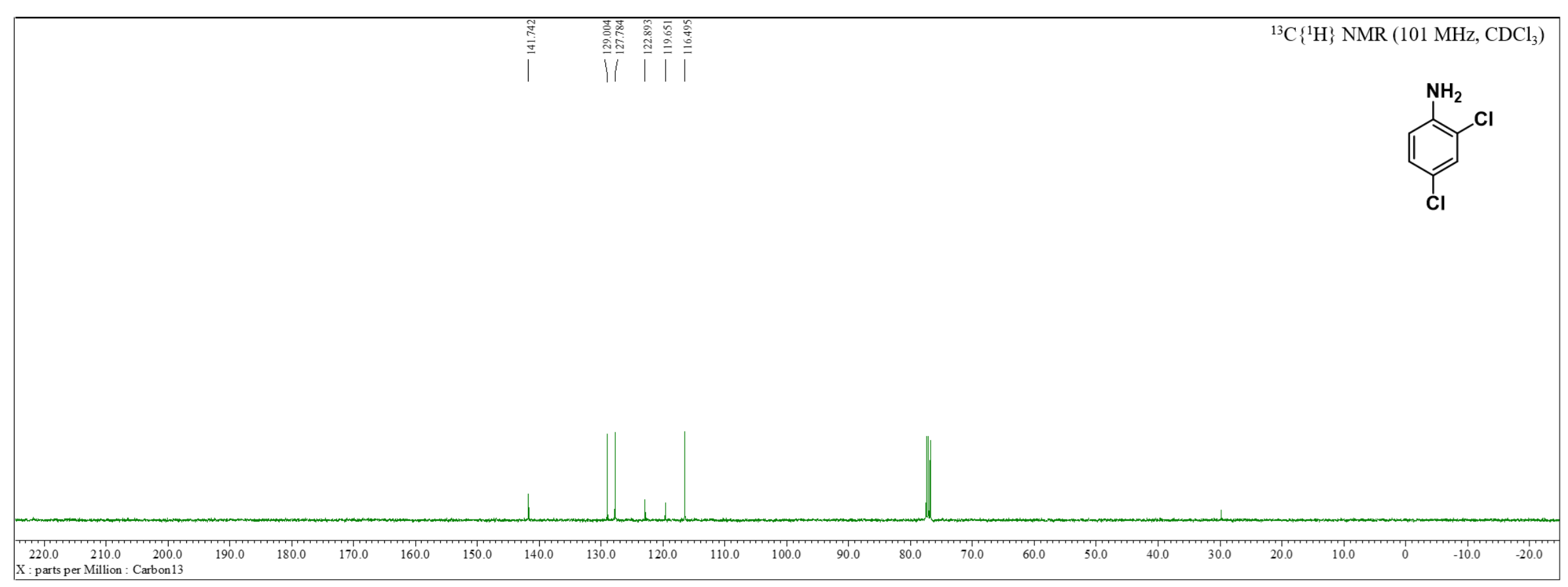

Figure S11. ${ }^{13} \mathrm{C}\left\{{ }^{1} \mathrm{H}\right\}$ NMR of $\mathbf{2 d}$ in $\mathrm{CDCl}_{3}$. 


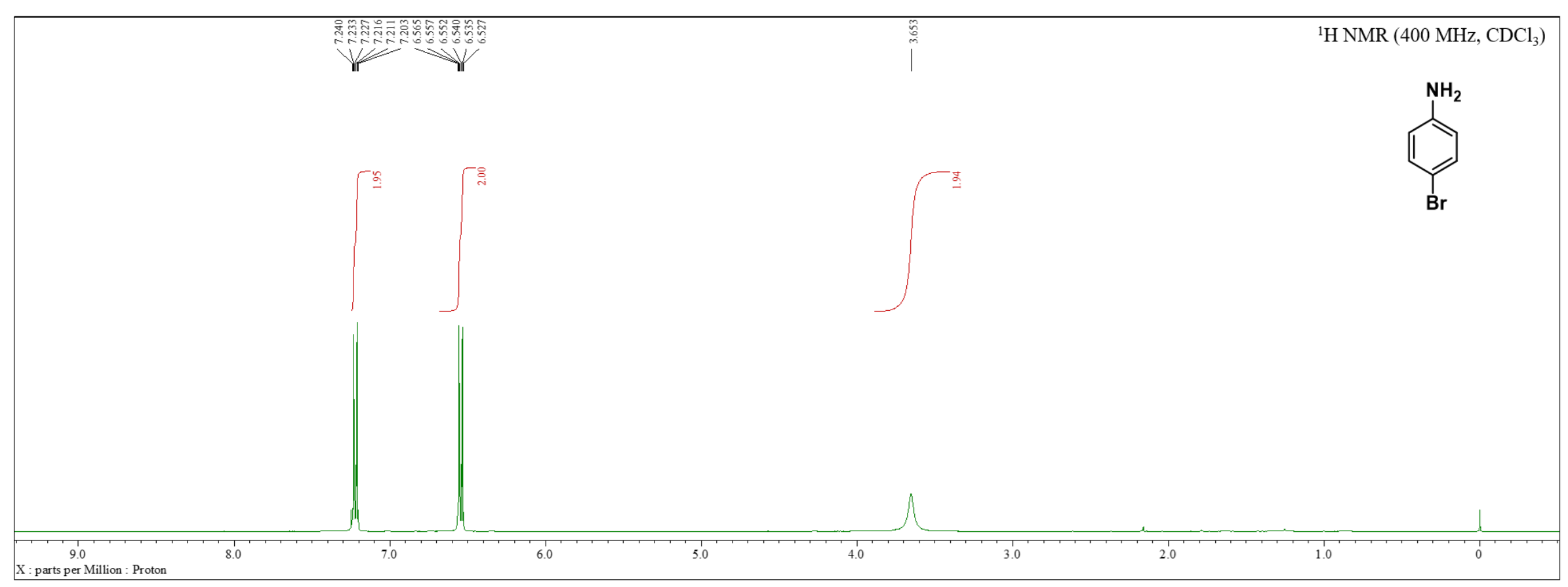

Figure S12. ${ }^{1} \mathrm{H}$ NMR of $2 \mathrm{e}$ in $\mathrm{CDCl}_{3}$. 


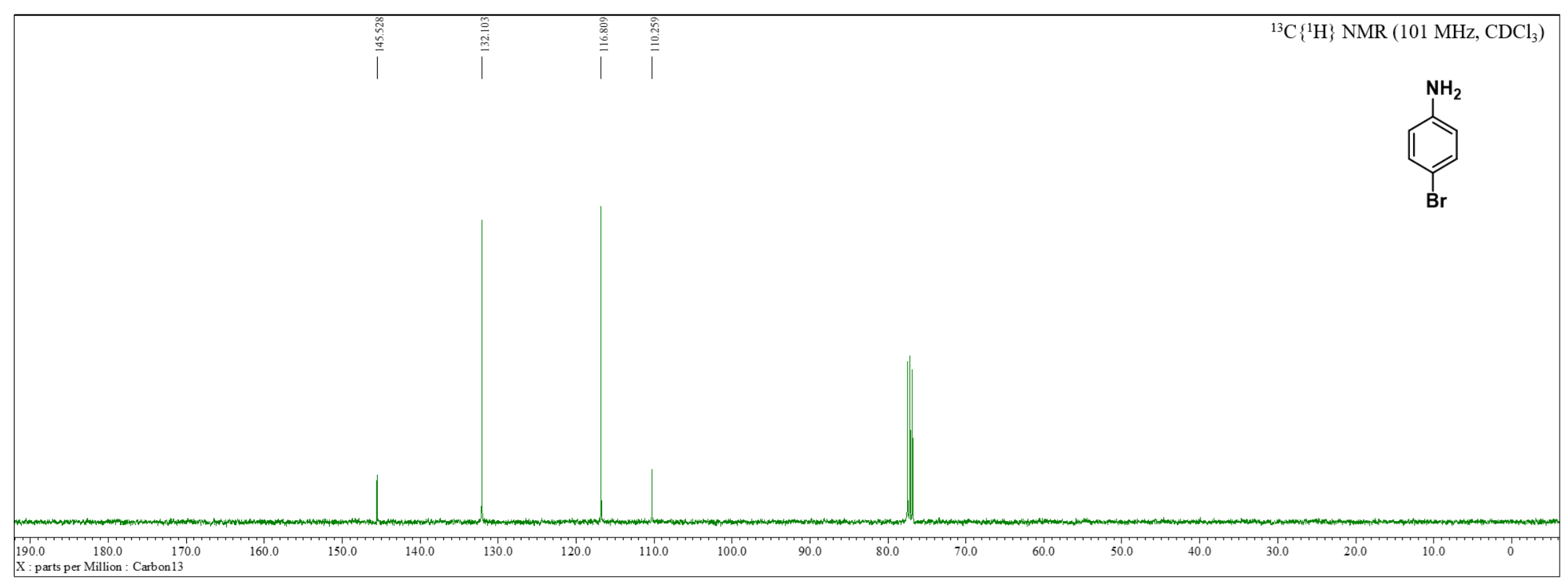

Figure S13. ${ }^{13} \mathrm{C}\left\{{ }^{1} \mathrm{H}\right\}$ NMR of $2 \mathbf{e}$ in $\mathrm{CDCl}_{3}$. 


$$
=
$$




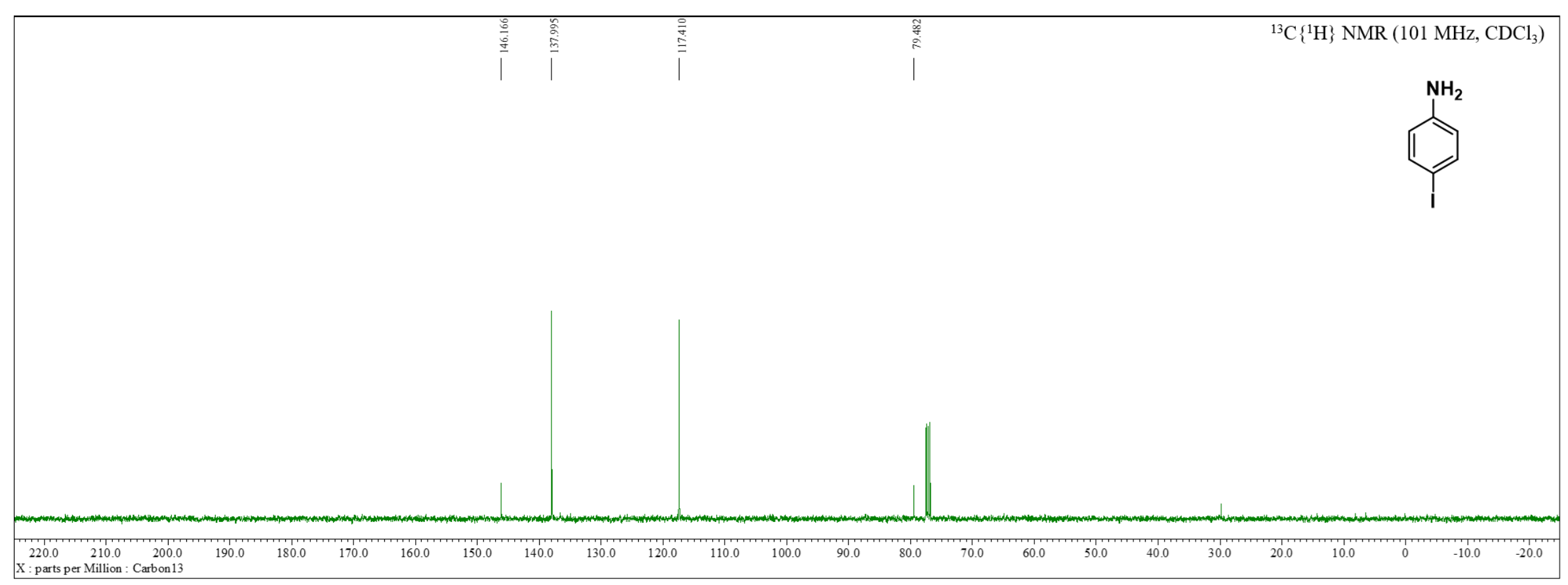

Figure S15. ${ }^{13} \mathrm{C}\left\{{ }^{1} \mathrm{H}\right\}$ NMR of $\mathbf{2 f}$ in $\mathrm{CDCl}_{3}$. 


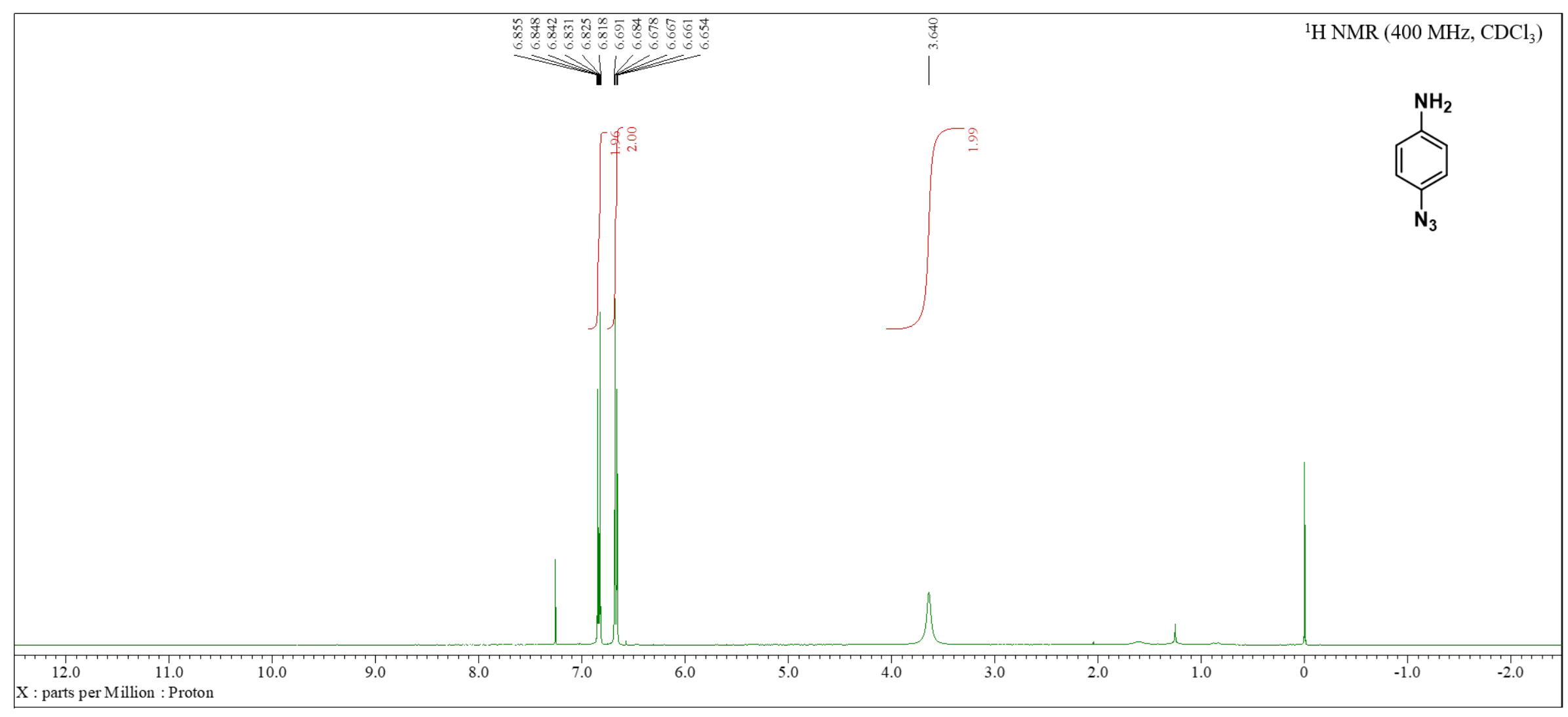

Figure S16. ${ }^{1} \mathrm{H} \mathrm{NMR}$ of $\mathbf{2 g}$ in $\mathrm{CDCl}_{3}$. 


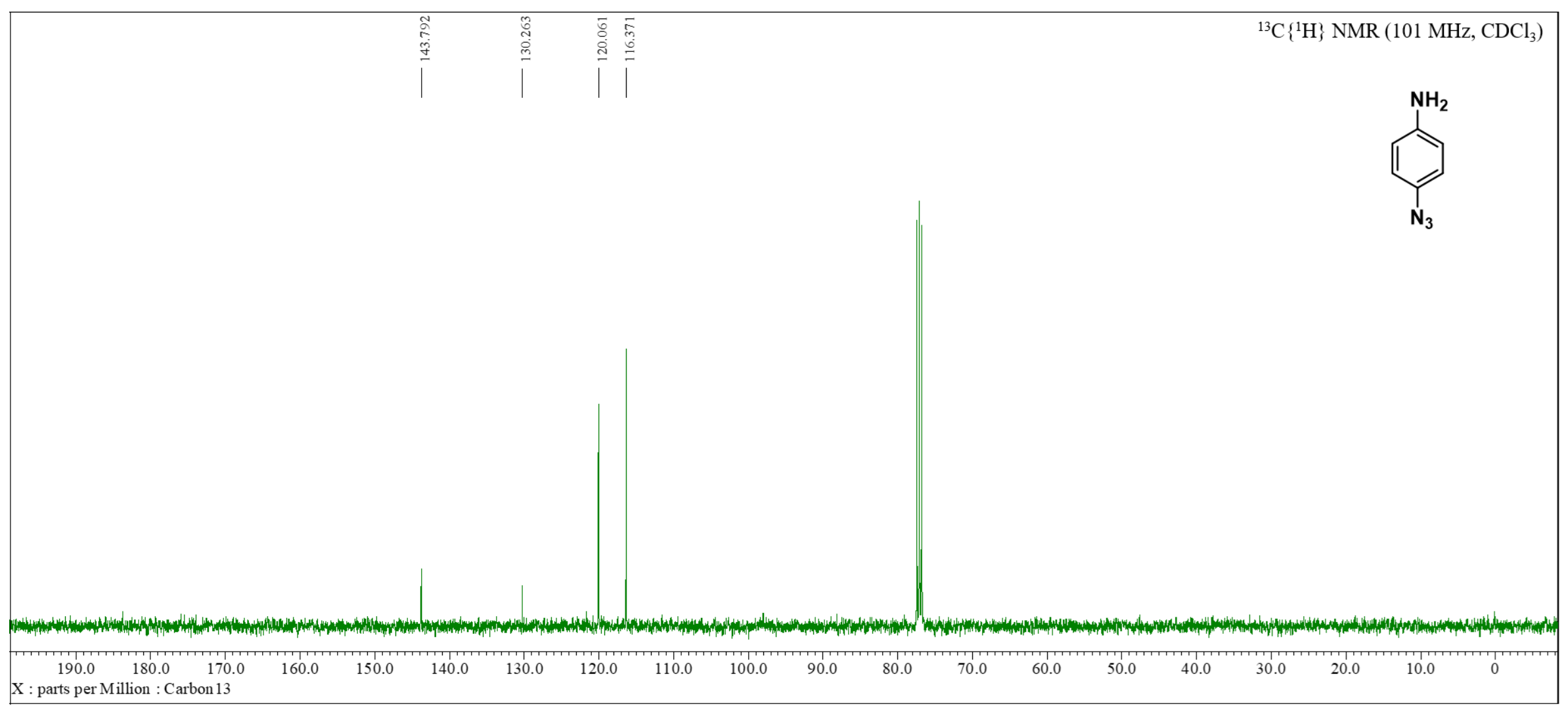

Figure S17. ${ }^{13} \mathrm{C}\left\{{ }^{1} \mathrm{H}\right\} \mathrm{NMR}$ of $\mathbf{2 g}$ in $\mathrm{CDCl}_{3}$, 


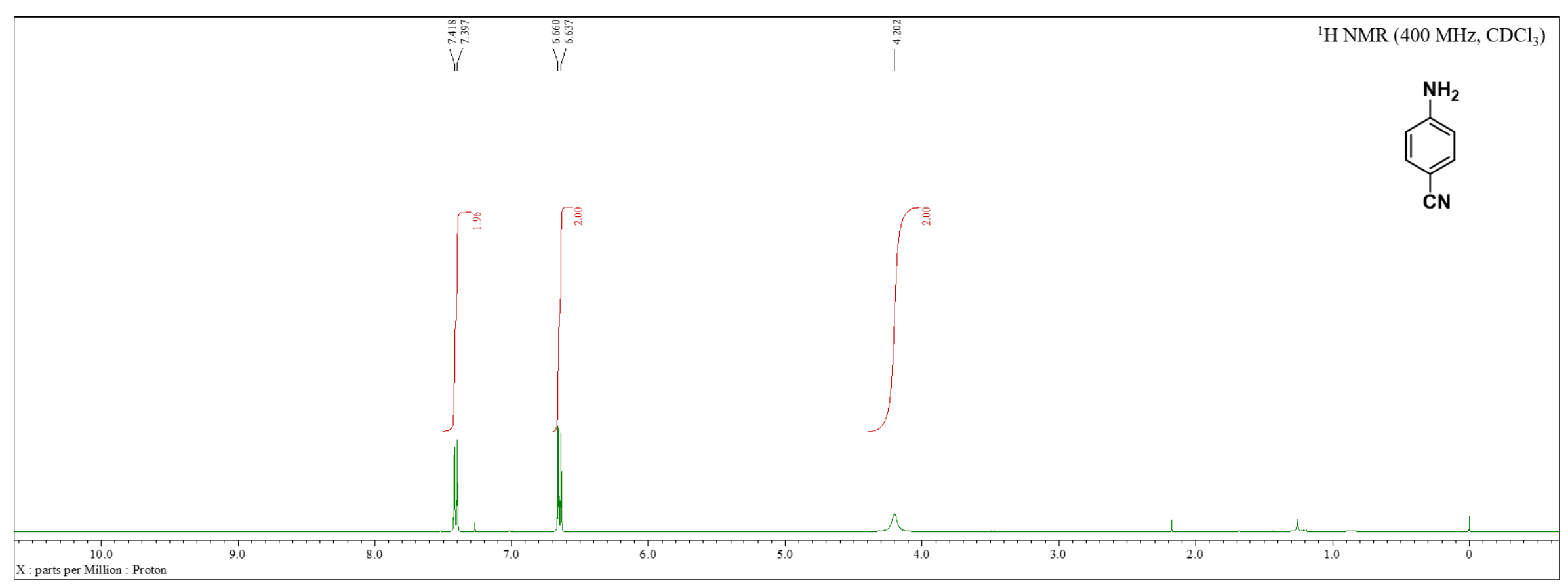

Figure S18. ${ }^{1} \mathrm{H}$ NMR of $\mathbf{2 h}$ in $\mathrm{CDCl}_{3}$ 


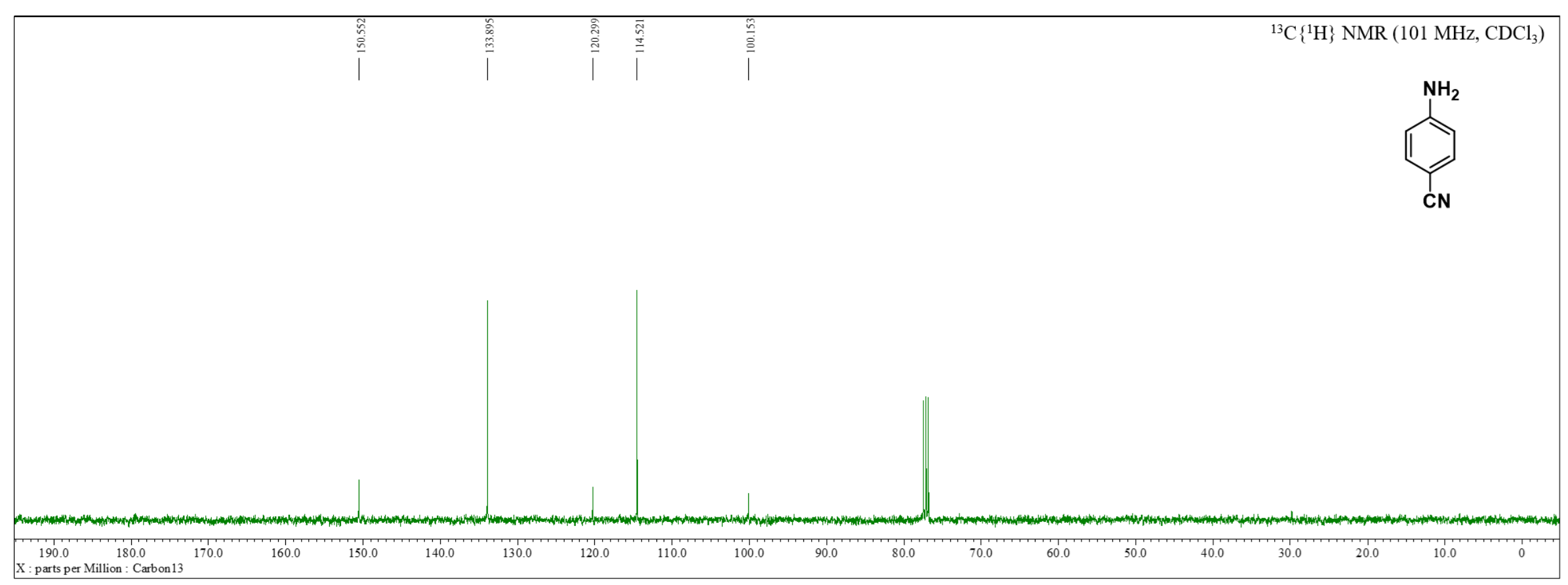

Figure S19. ${ }^{13} \mathrm{C}\left\{{ }^{1} \mathrm{H}\right\}$ NMR of $\mathbf{2 h}$ in $\mathrm{CDCl}_{3}$. 


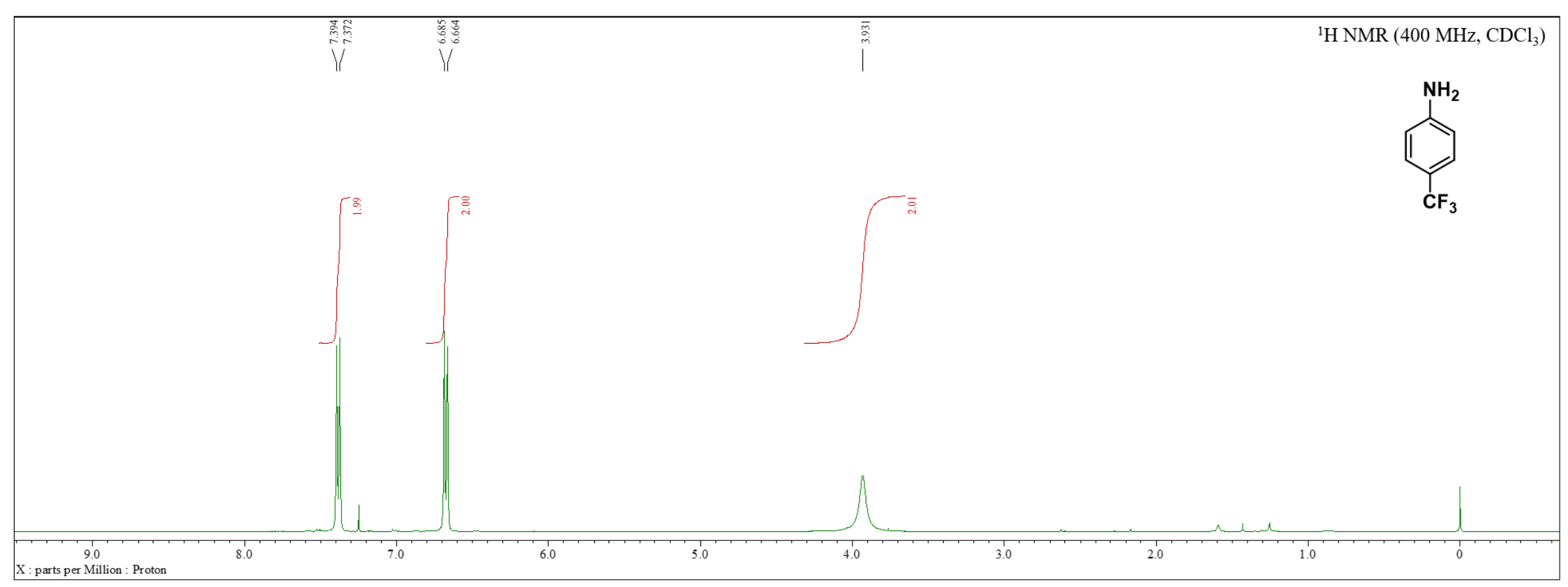

Figure S20. ${ }^{1} \mathrm{H}$ NMR of $2 \mathrm{i}$ in $\mathrm{CDCl}_{3}$. 


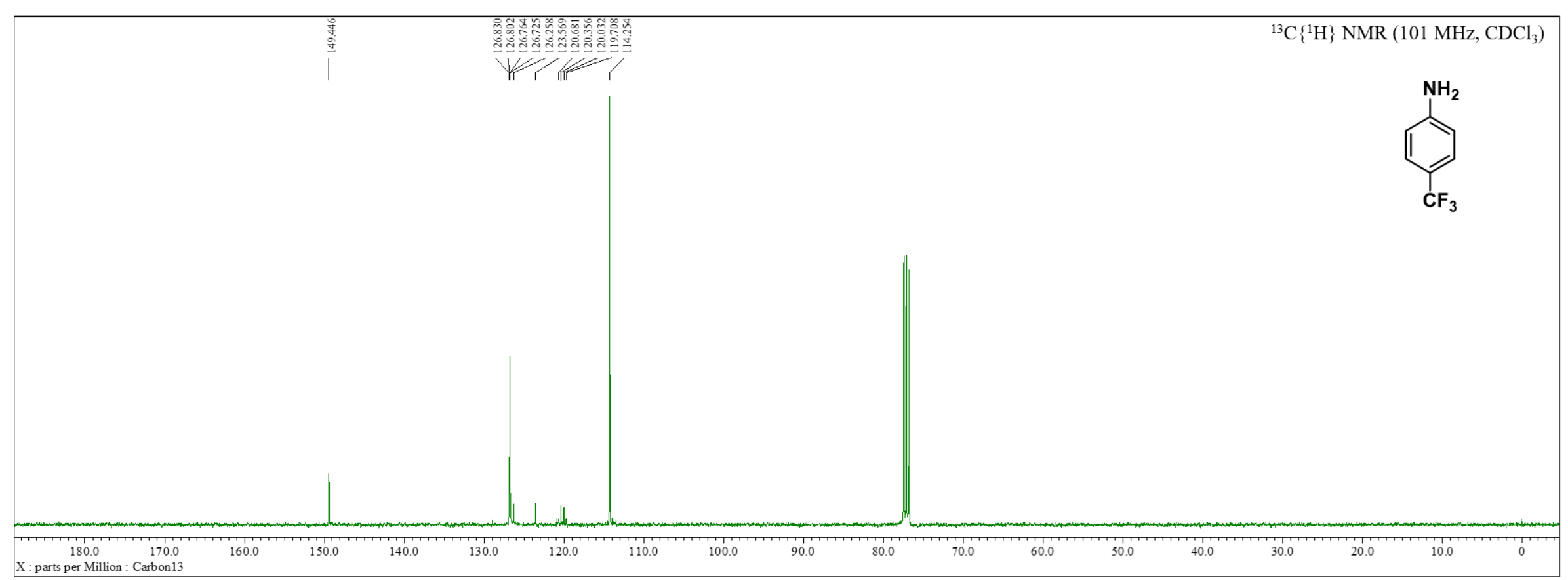

Figure S21. ${ }^{13} \mathrm{C}\left\{{ }^{1} \mathrm{H}\right\}$ NMR of $\mathbf{2 i}$ in $\mathrm{CDCl}_{3}$ 


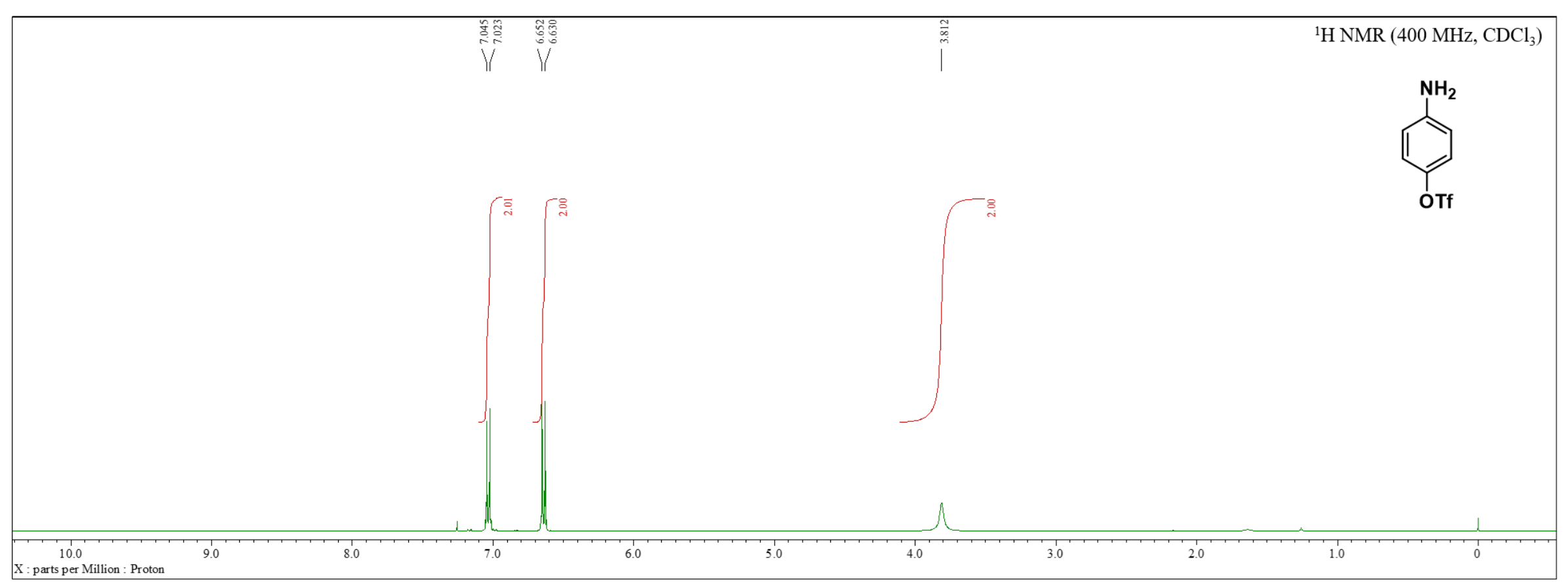

Figure $\mathbf{S 2 2} .{ }^{1} \mathrm{H} \mathrm{NMR}$ of $\mathbf{2} \mathbf{j}$ in $\mathrm{CDCl}_{3}$. 


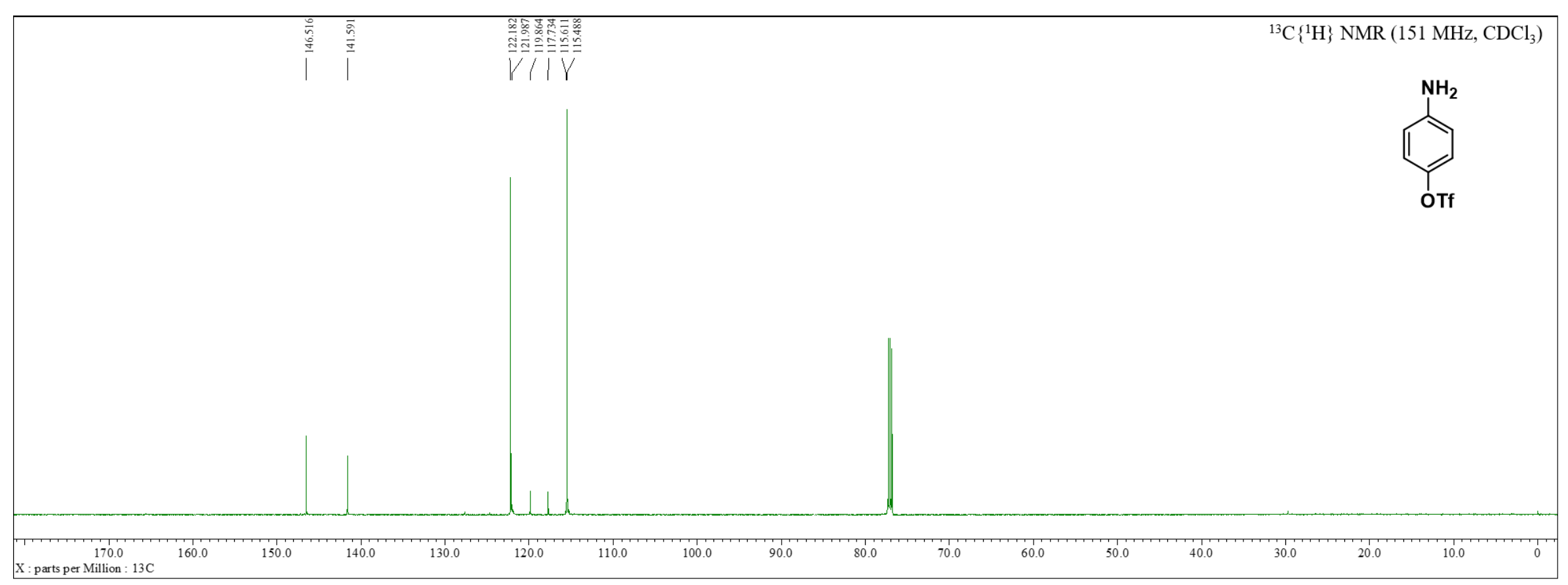

Figure S23. ${ }^{13} \mathrm{C}\left\{{ }^{1} \mathrm{H}\right\}$ NMR of $\mathbf{2 j}$ in $\mathrm{CDCl}_{3}$. 


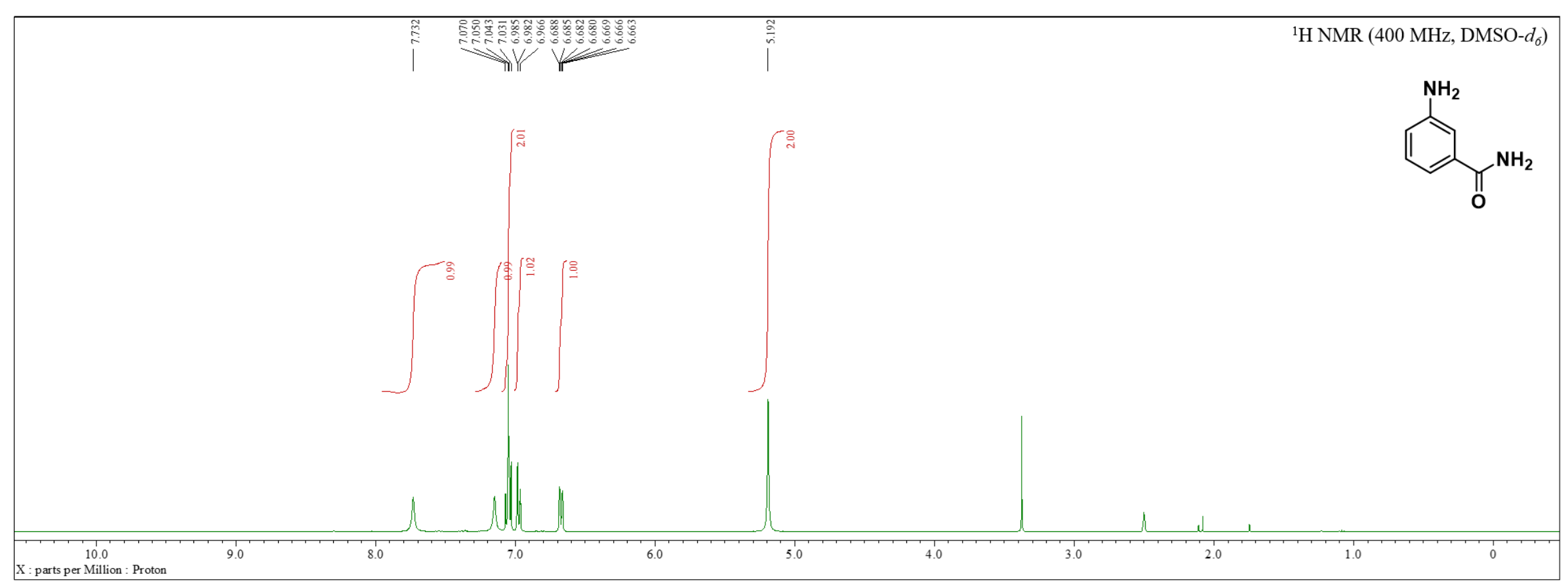

Figure S24. ${ }^{1} \mathrm{H}$ NMR of $\mathbf{2 k}$ in DMSO- $d_{6}$. 


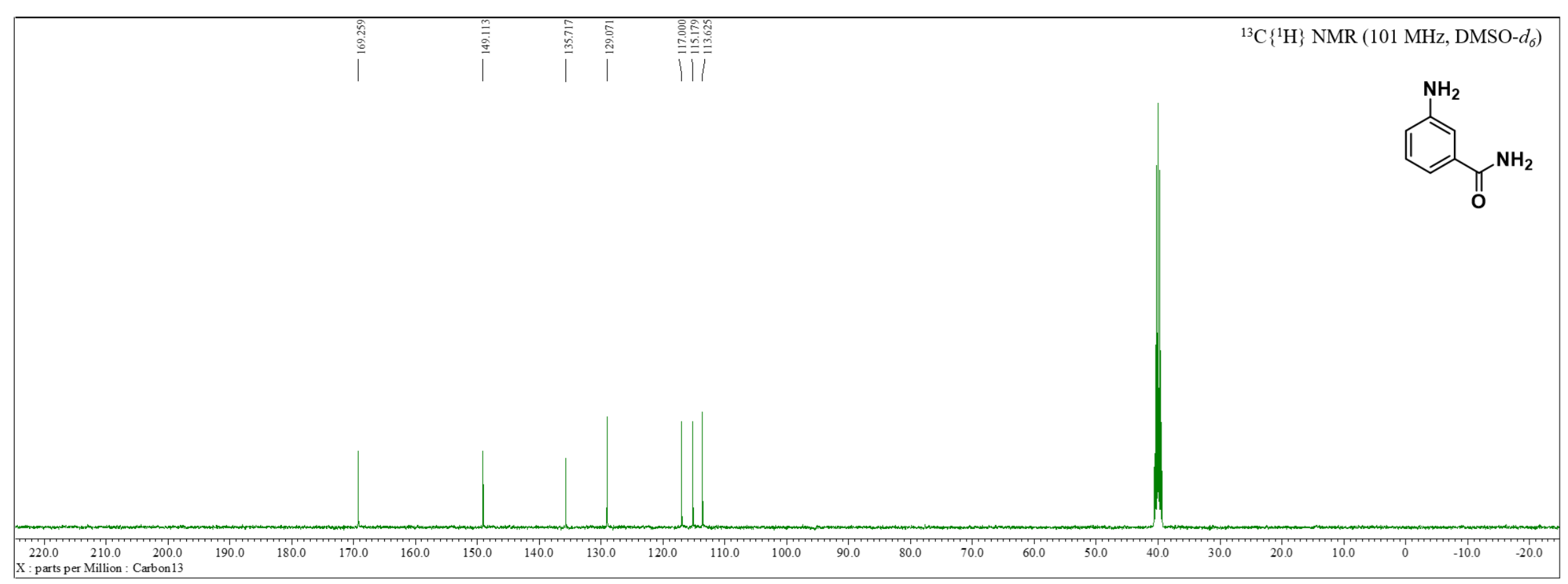

Figure S25. ${ }^{13} \mathrm{C}\left\{{ }^{1} \mathrm{H}\right\}$ NMR of $\mathbf{2 k}$ in DMSO- $d_{6}$ 


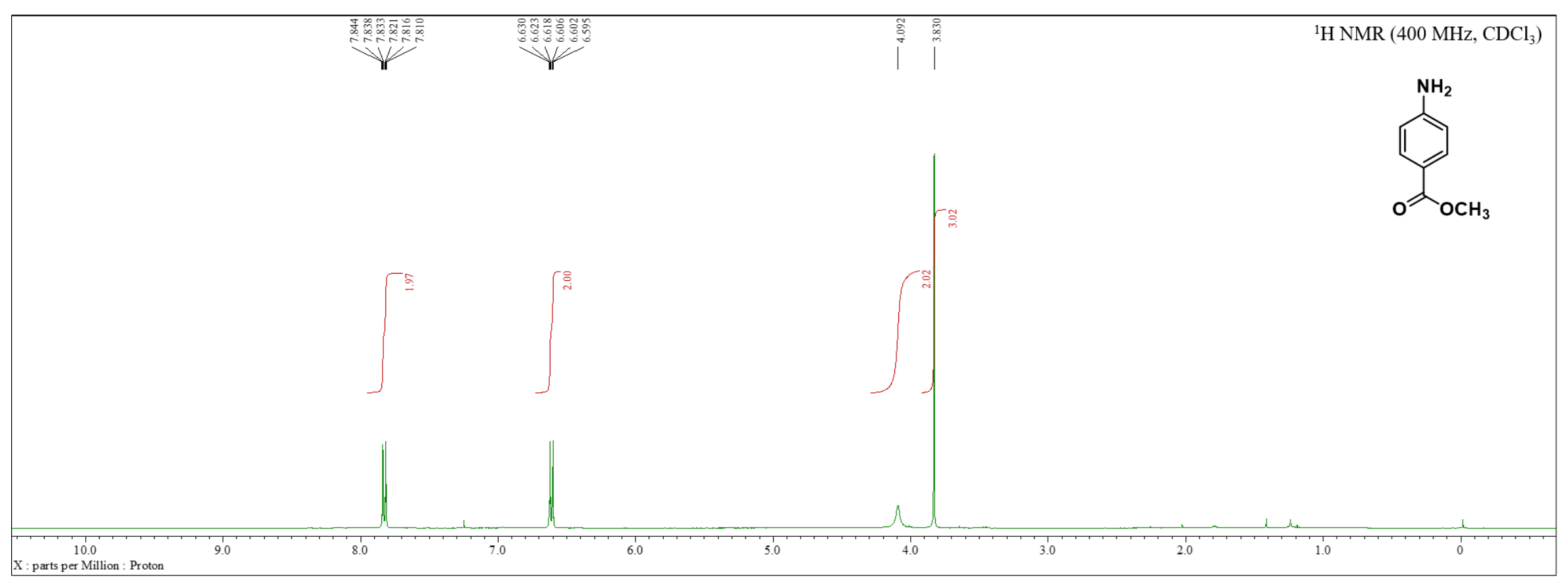

Figure S26. ${ }^{1} \mathrm{H}$ NMR of $\mathbf{2 l}$ in $\mathrm{CDCl}_{3}$ 


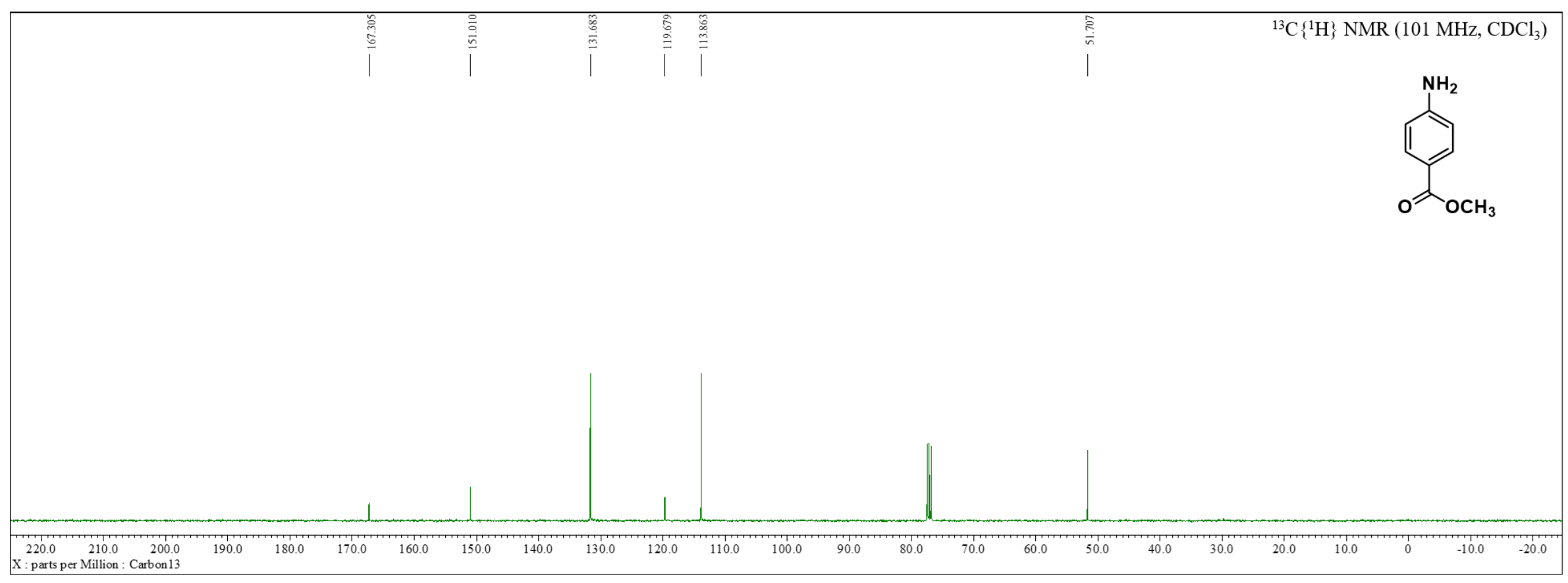

Figure S27. ${ }^{13} \mathrm{C}\left\{{ }^{1} \mathrm{H}\right\}$ NMR of $\mathbf{2 l}$ in $\mathrm{CDCl}_{3}$.

S31 


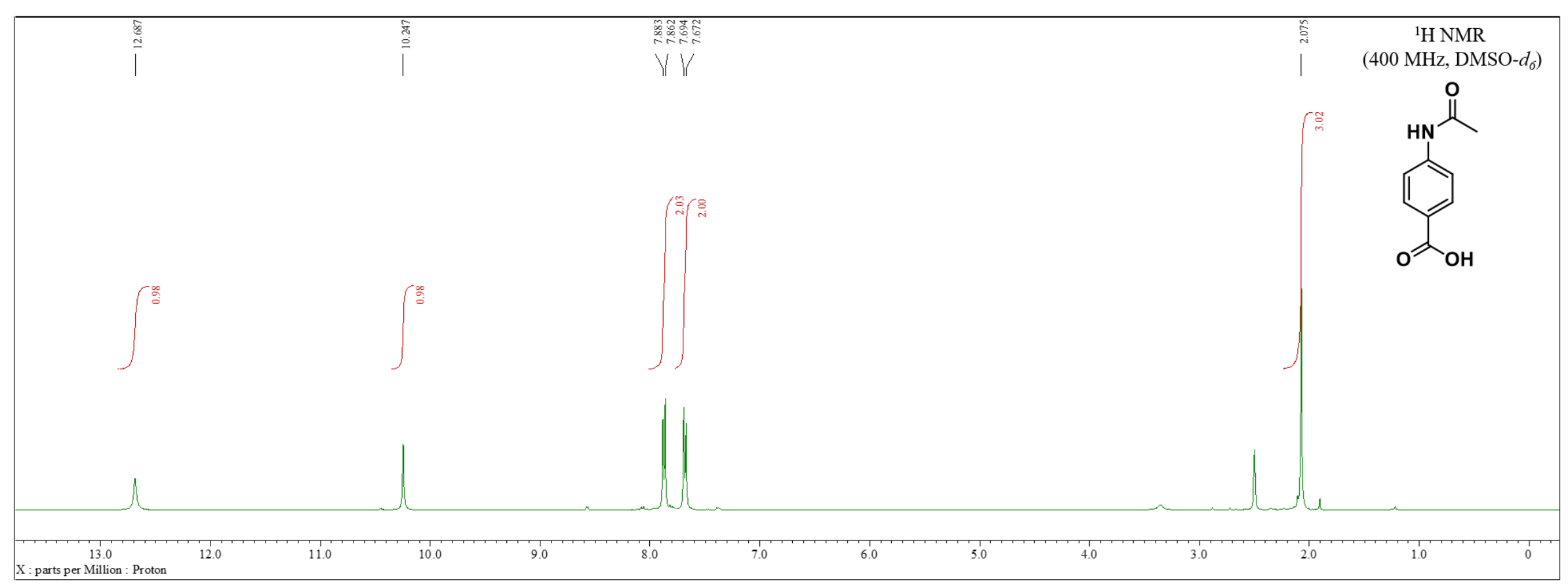

Figure S28. ${ }^{1} \mathrm{H}$ NMR of $\mathbf{2 m}$ in DMSO- $d_{6}$. 


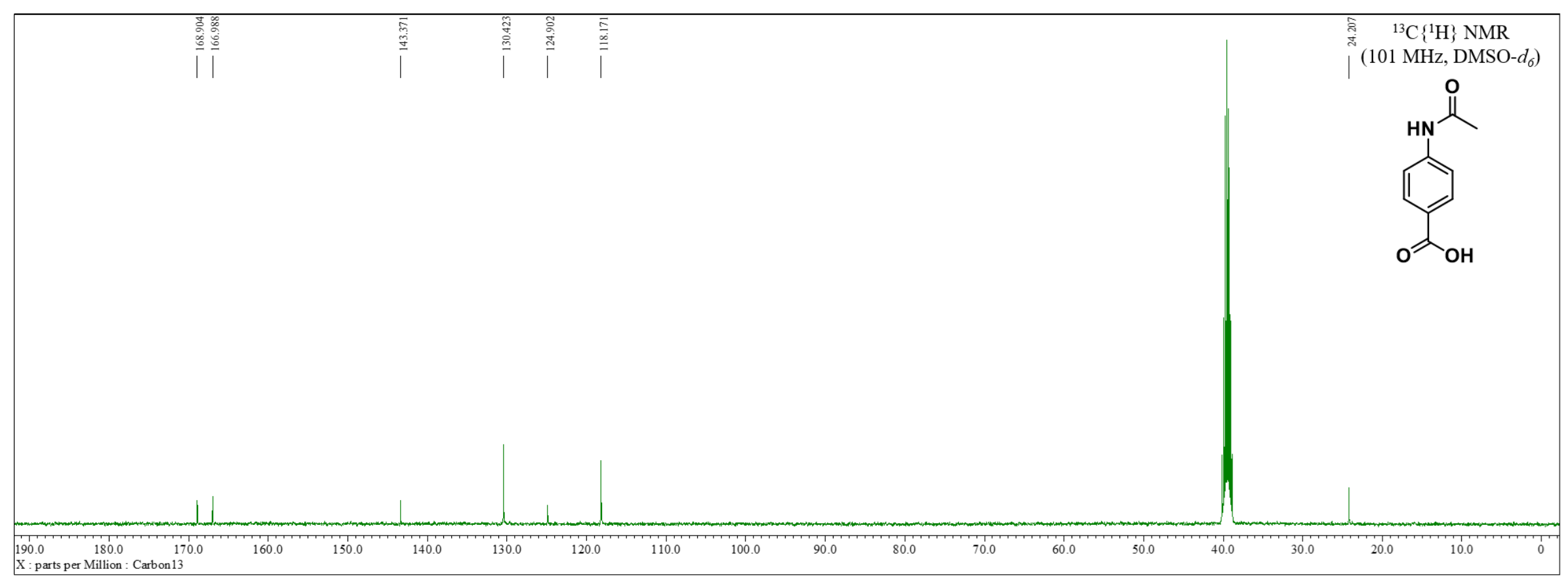

Figure S29. ${ }^{13} \mathrm{C}\left\{{ }^{1} \mathrm{H}\right\}$ NMR of $\mathbf{2 m}$ in DMSO- $d_{6}$. 


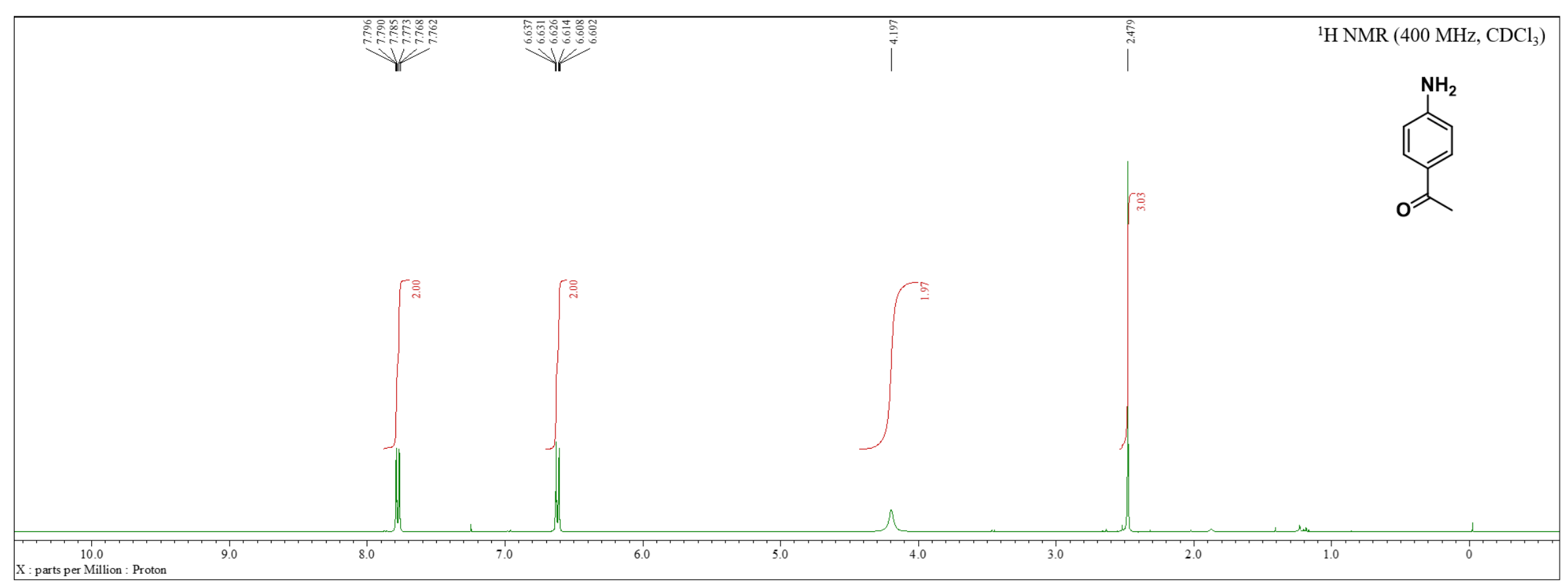

Figure S30. ${ }^{1} \mathrm{H} \mathrm{NMR}$ of $\mathbf{2 n}$ in $\mathrm{CDCl}_{3}$ 


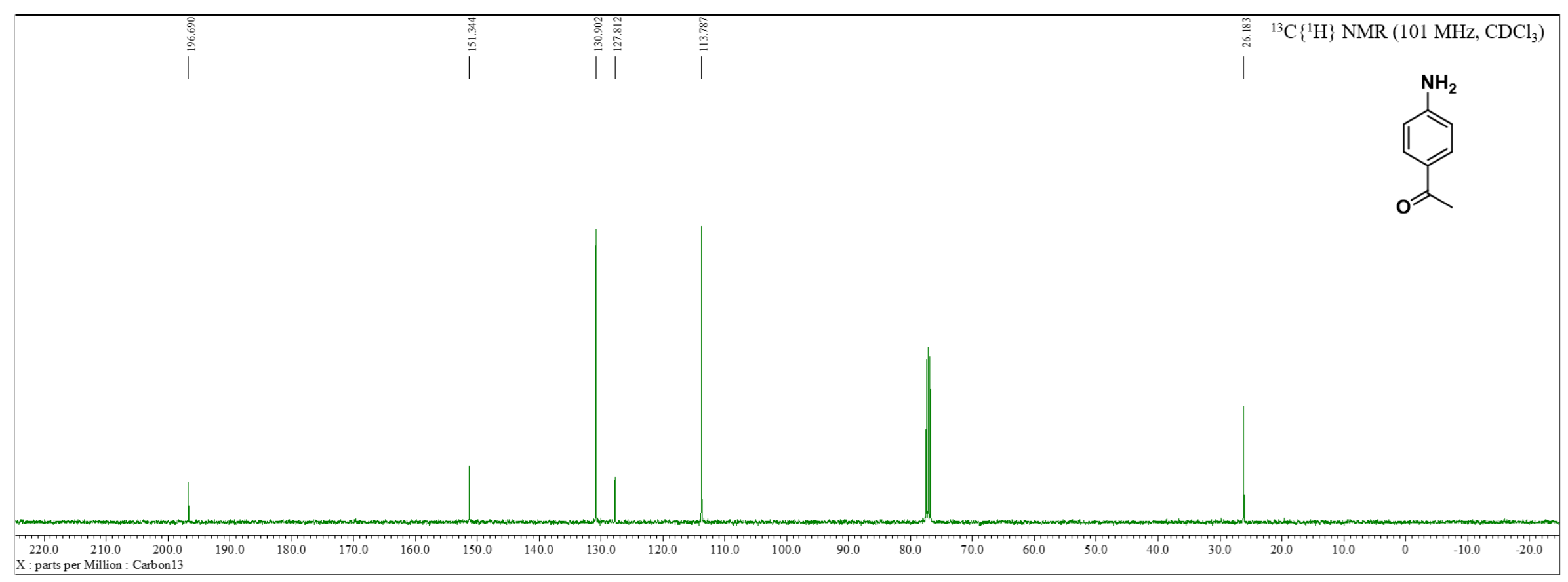

Figure S31. ${ }^{13} \mathrm{C}\left\{{ }^{1} \mathrm{H}\right\}$ NMR of $\mathbf{2 n}$ in $\mathrm{CDCl}_{3}$ 


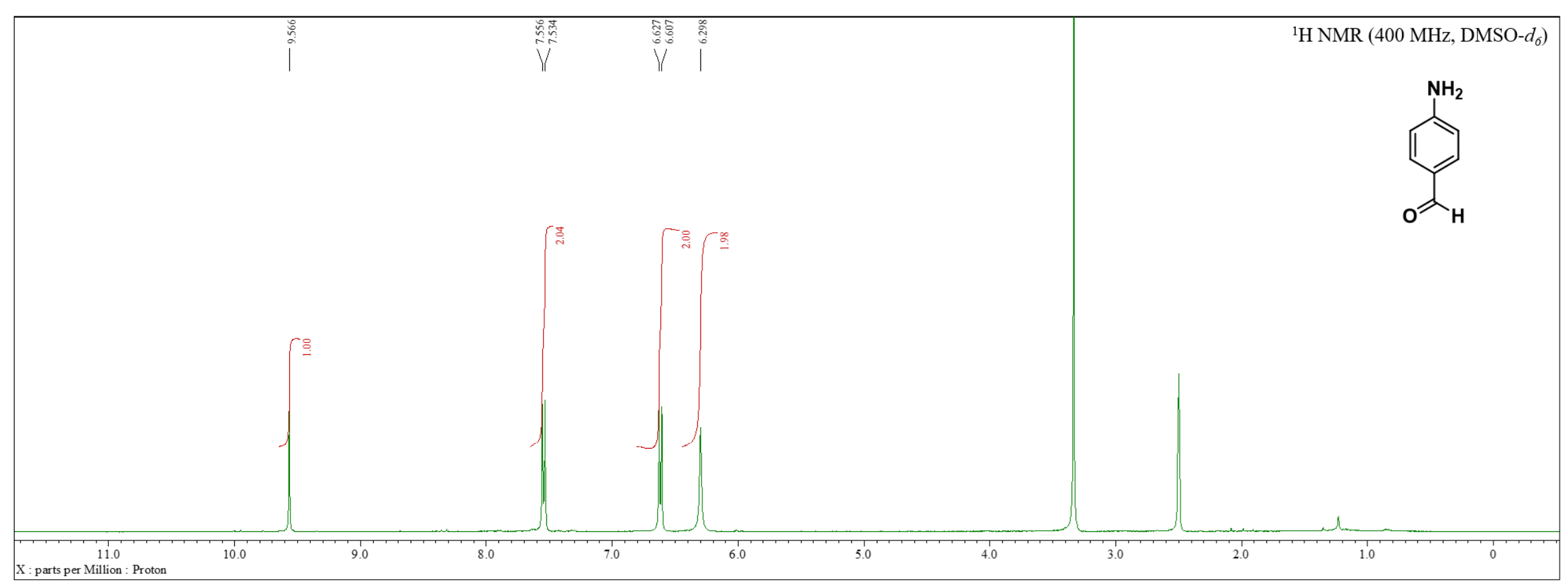

Figure S32. ${ }^{1} \mathrm{H}$ NMR of 20 in DMSO- $d_{6}$. 


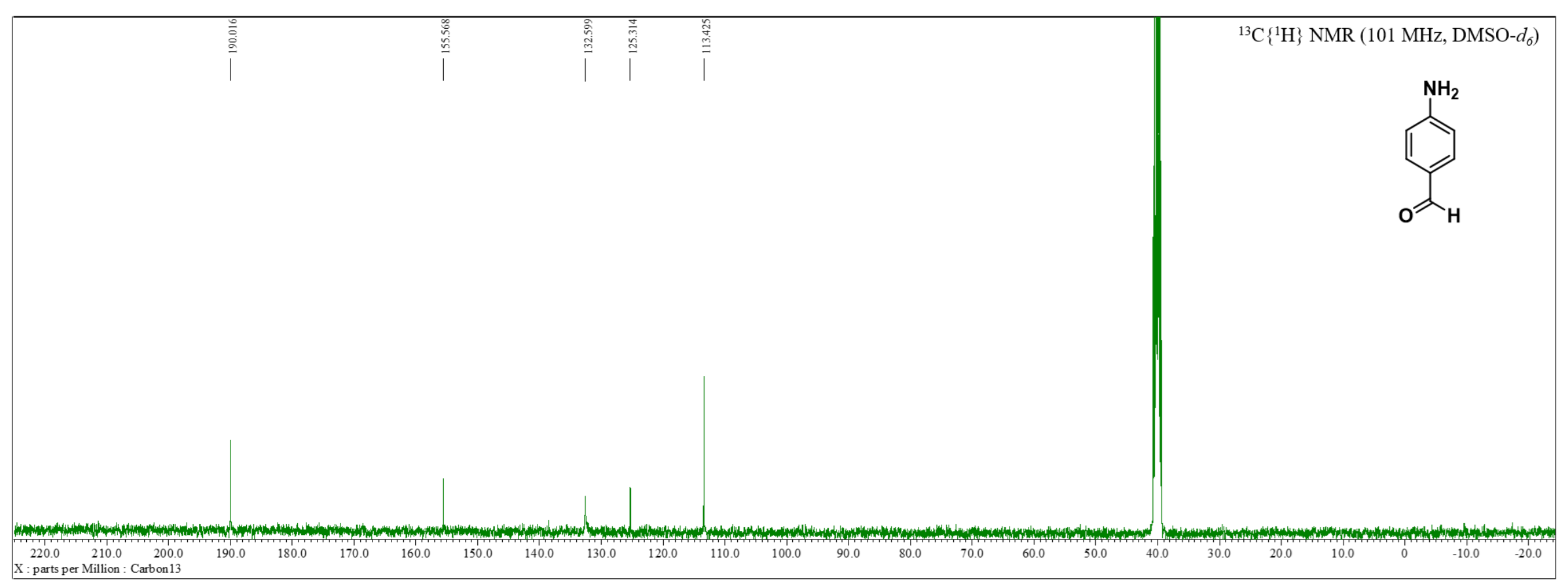

Figure S33. ${ }^{13} \mathrm{C}\left\{{ }^{1} \mathrm{H}\right\}$ NMR of 20 in DMSO- $d_{6}$ 


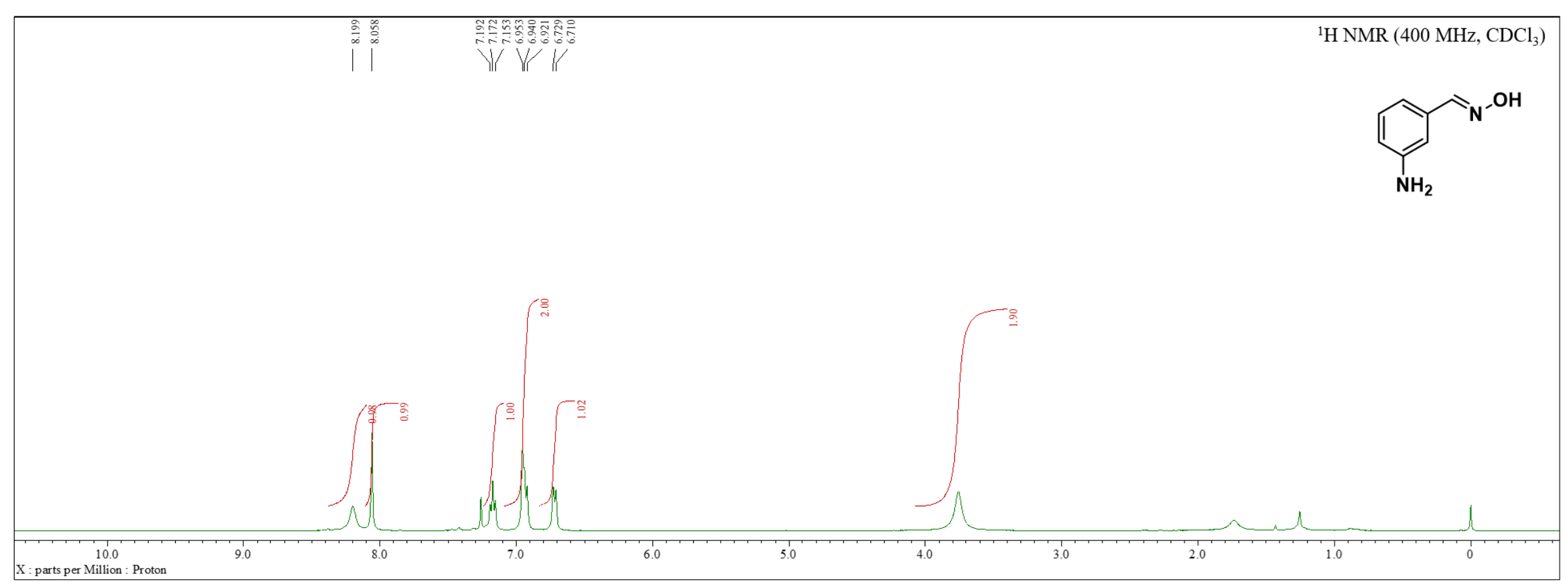

Figure S34. ${ }^{1} \mathrm{H}$ NMR of $\mathbf{2 p}$ in $\mathrm{CDCl}_{3}$ 


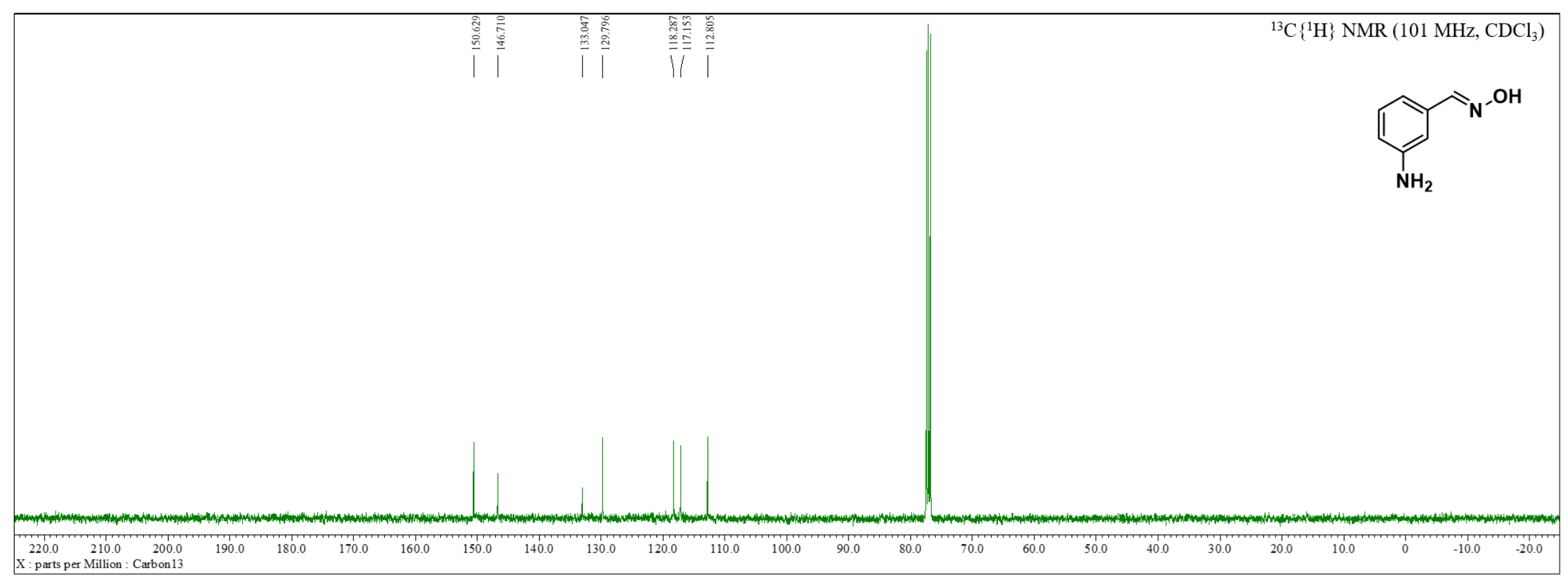

Figure S35. ${ }^{13} \mathrm{C}\left\{{ }^{1} \mathrm{H}\right\}$ NMR of $\mathbf{2 p}$ in $\mathrm{CDCl}_{3}$. 


$$
\bar{b}
$$




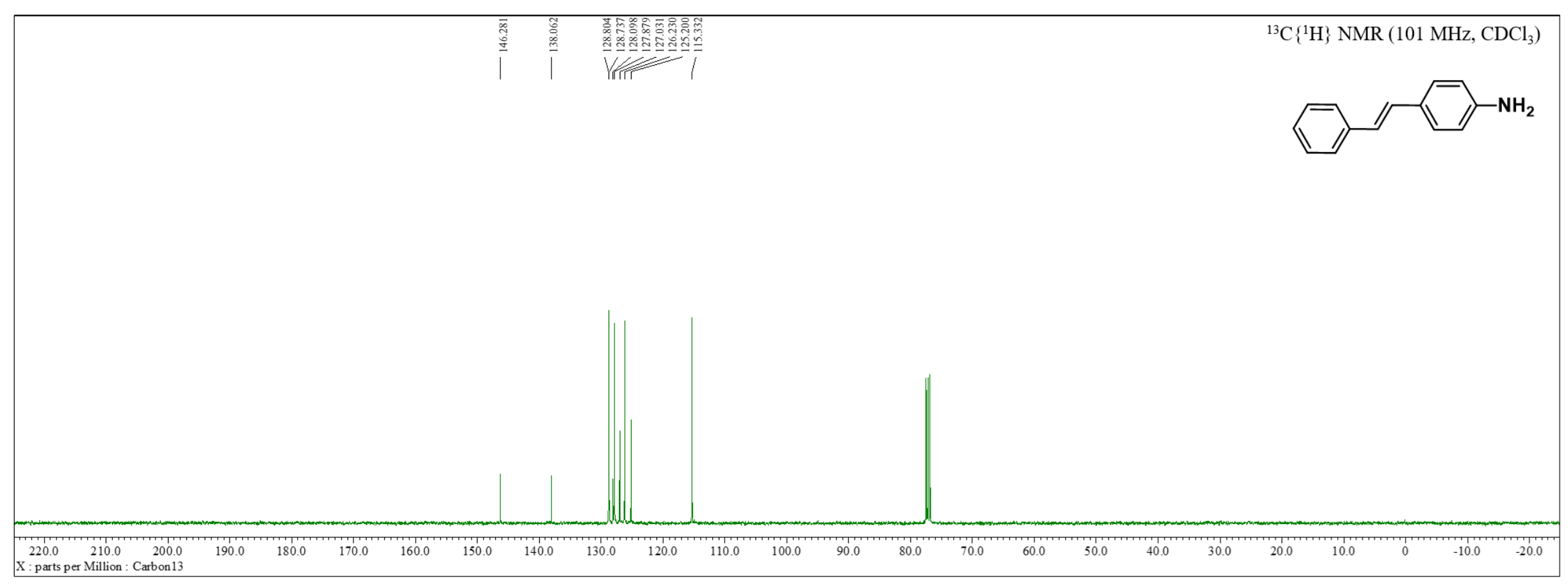

Figure S37. ${ }^{13} \mathrm{C}\left\{{ }^{1} \mathrm{H}\right\}$ NMR of $\mathbf{2 q}$ in $\mathrm{CDCl}_{3}$ 


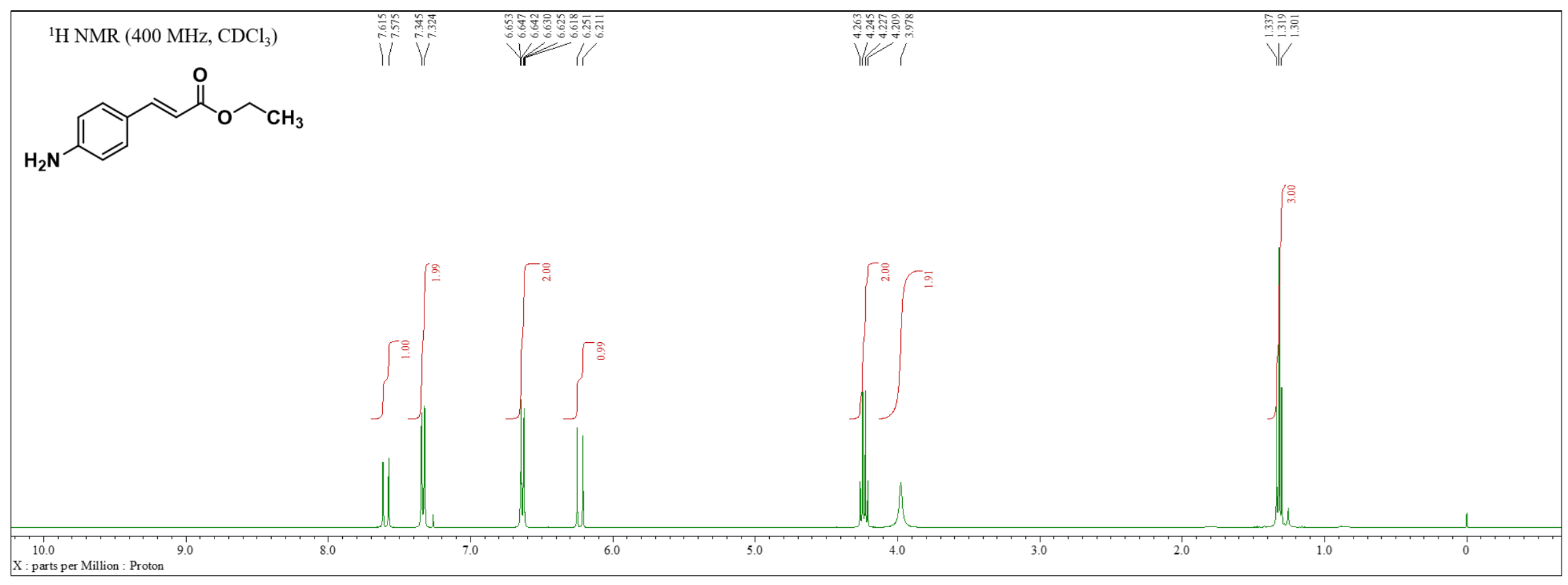

Figure S38. ${ }^{1} \mathrm{H}$ NMR of $\mathbf{2} \mathbf{r}$ in $\mathrm{CDCl}_{3}$.

S42 


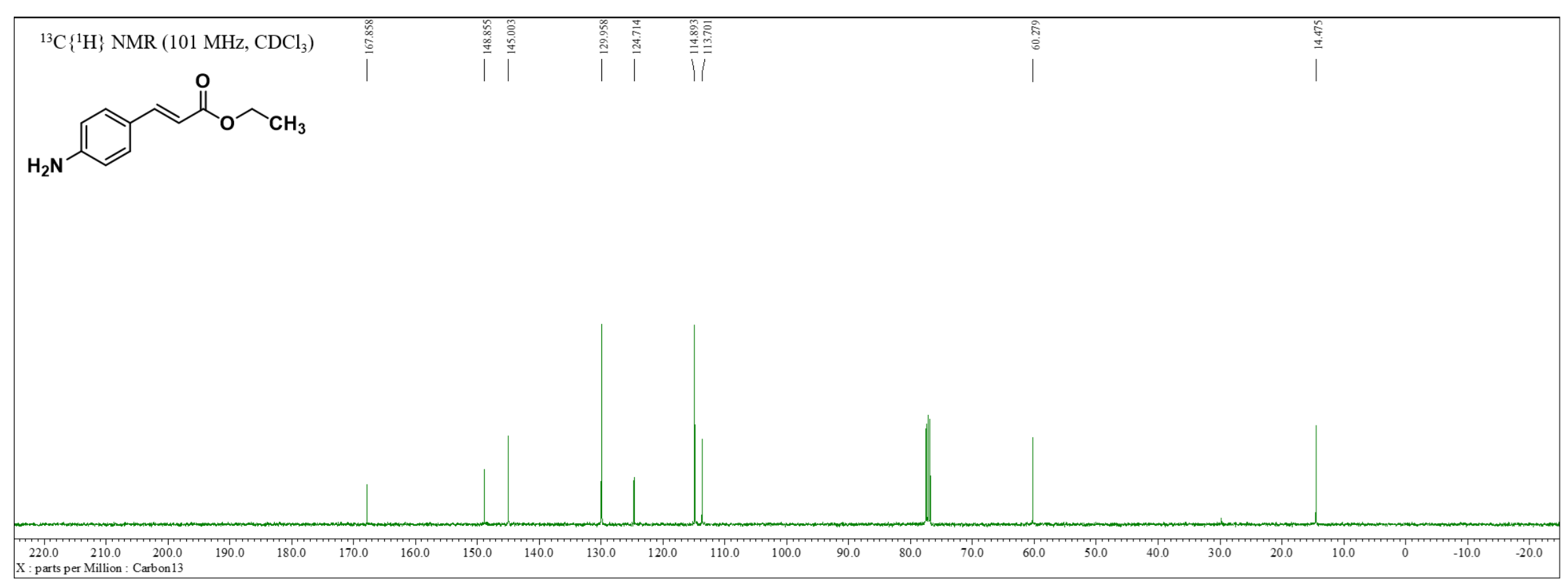

Figure S39. ${ }^{13} \mathrm{C}\left\{{ }^{1} \mathrm{H}\right\}$ NMR of $\mathbf{2 r}$ in $\mathrm{CDCl}_{3}$. 


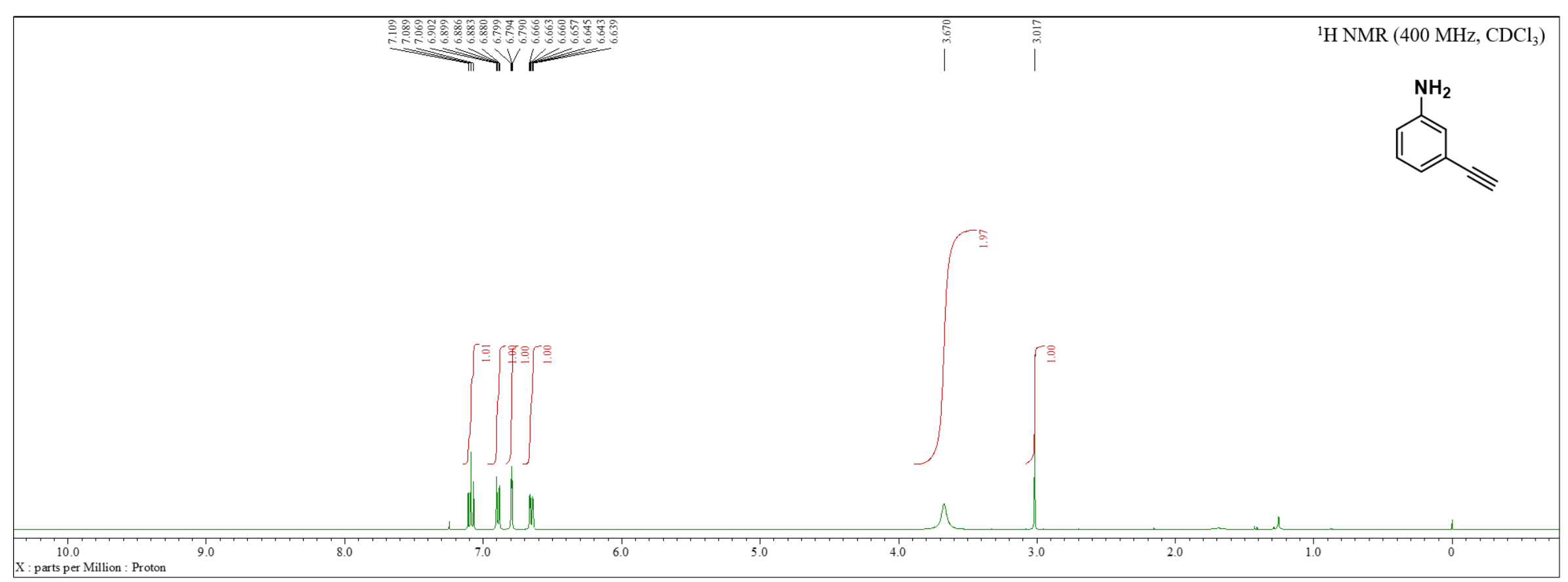

Figure S40. ${ }^{1} \mathrm{H}$ NMR of $2 s$ in $\mathrm{CDCl}_{3}$ 


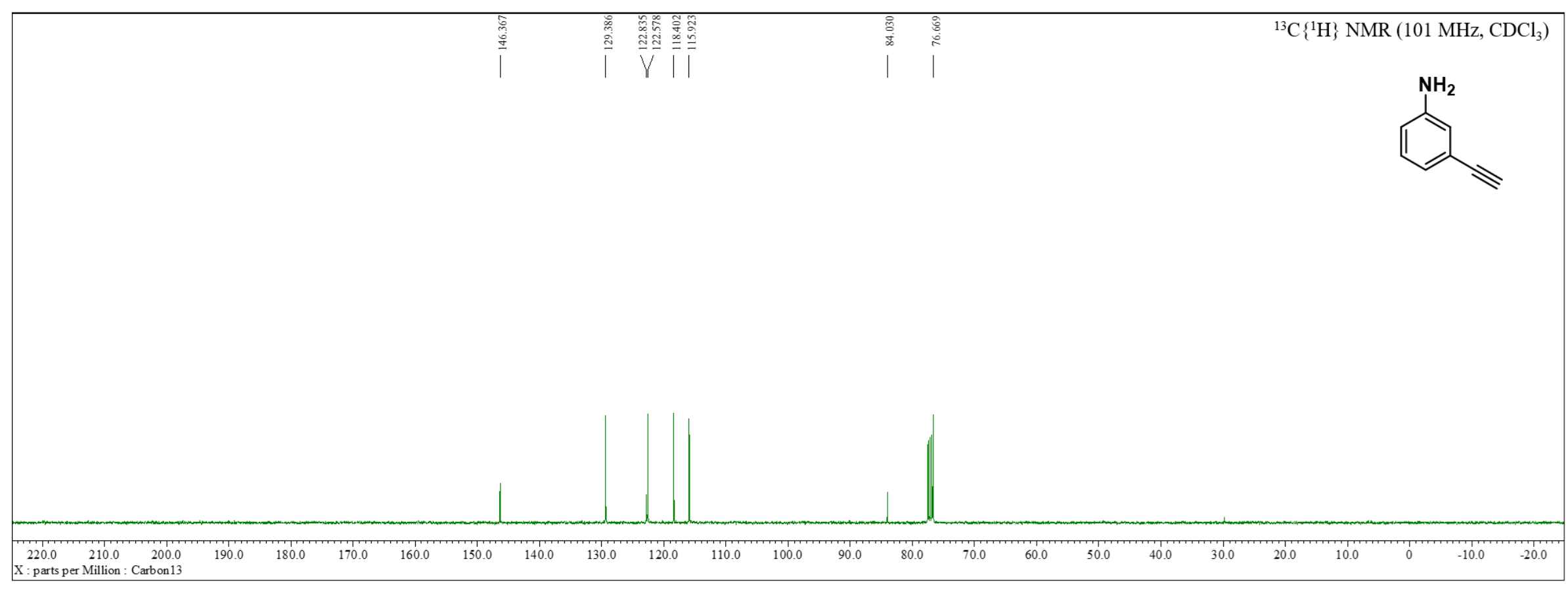

Figure S41. ${ }^{13} \mathrm{C}\left\{{ }^{1} \mathrm{H}\right\}$ NMR of 2 s in $\mathrm{CDCl}_{3}$.

S45 


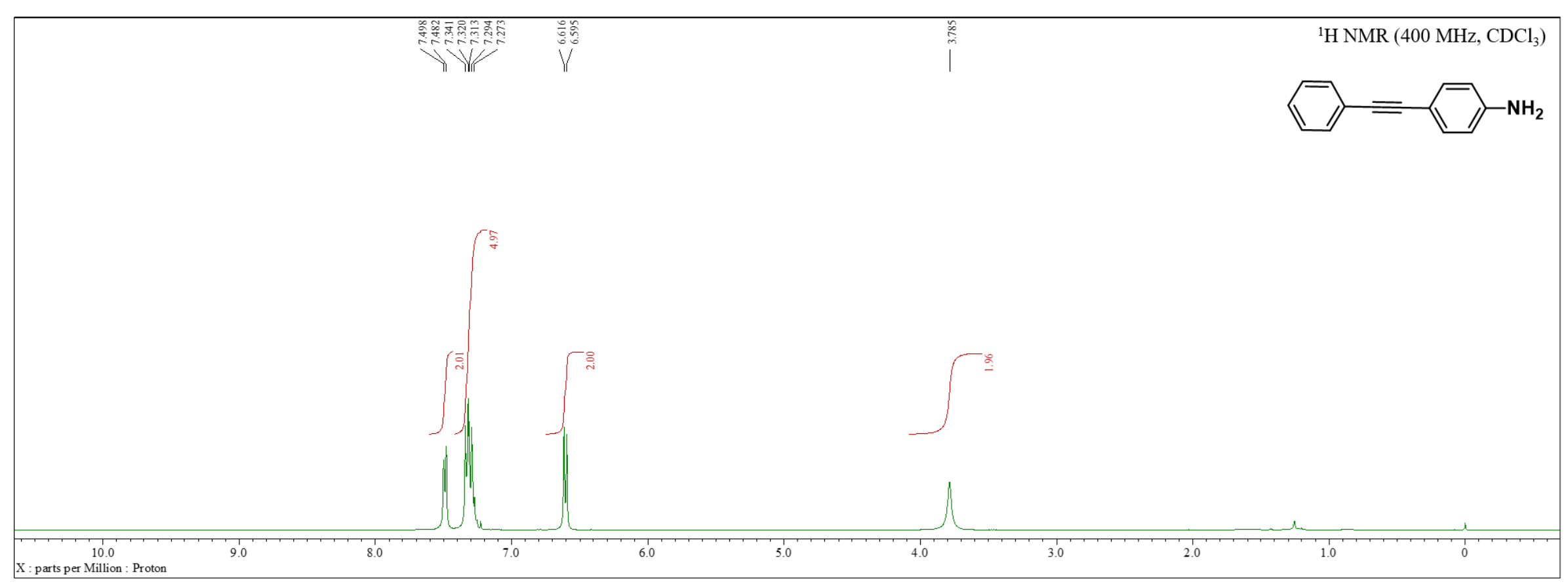

Figure $\mathbf{S 4 2} .{ }^{1} \mathrm{H} \mathrm{NMR}$ of $\mathbf{2 t}$ in $\mathrm{CDCl}_{3}$ 


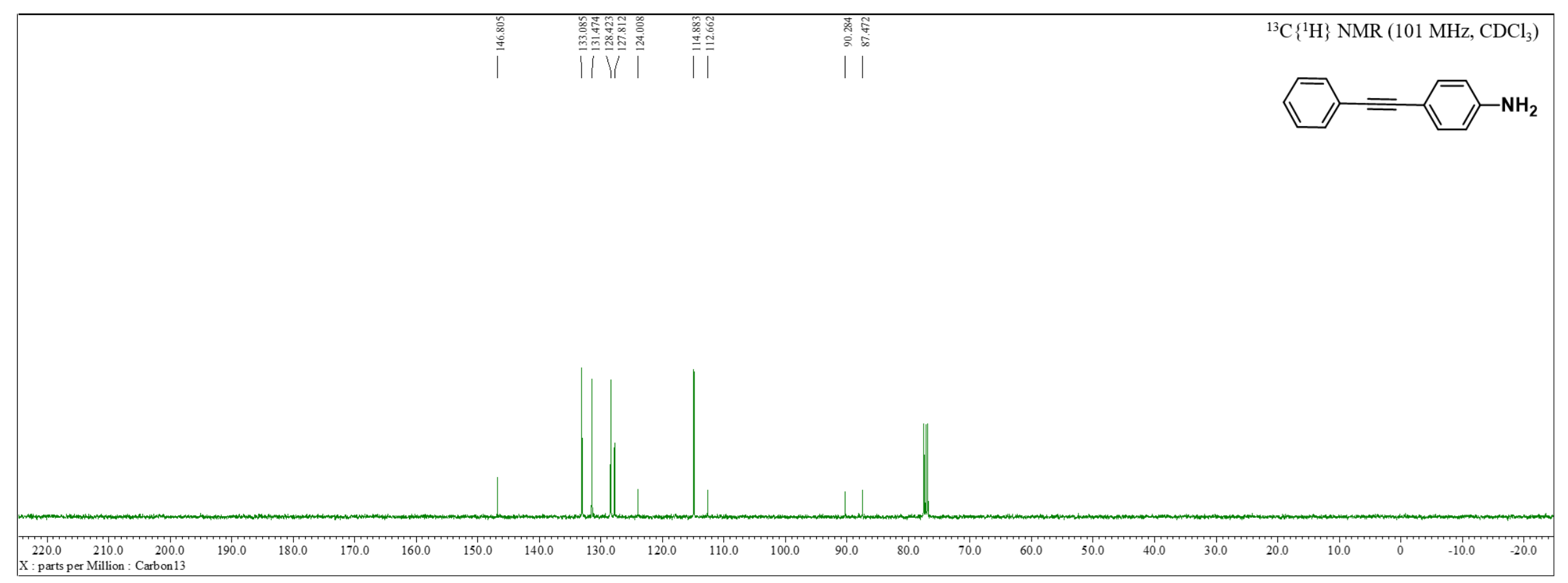

Figure S43. ${ }^{13} \mathrm{C}\left\{{ }^{1} \mathrm{H}\right\}$ NMR of $\mathbf{2 t}$ in $\mathrm{CDCl}_{3}$.

S47 


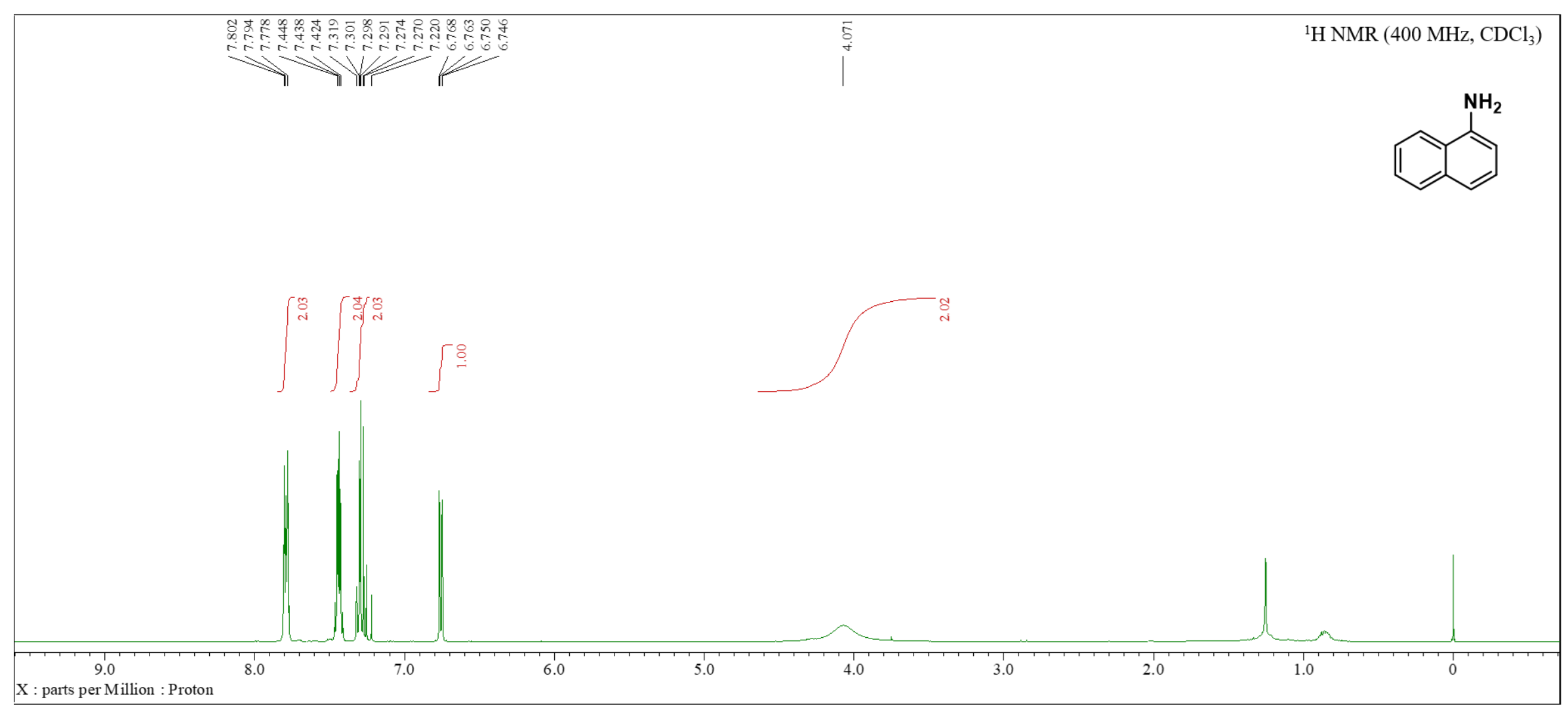

Figure $\mathbf{S 4 4} .{ }^{1} \mathrm{H} \mathrm{NMR}$ of $\mathbf{2} \mathbf{u}$ in $\mathrm{CDCl}_{3}$ 


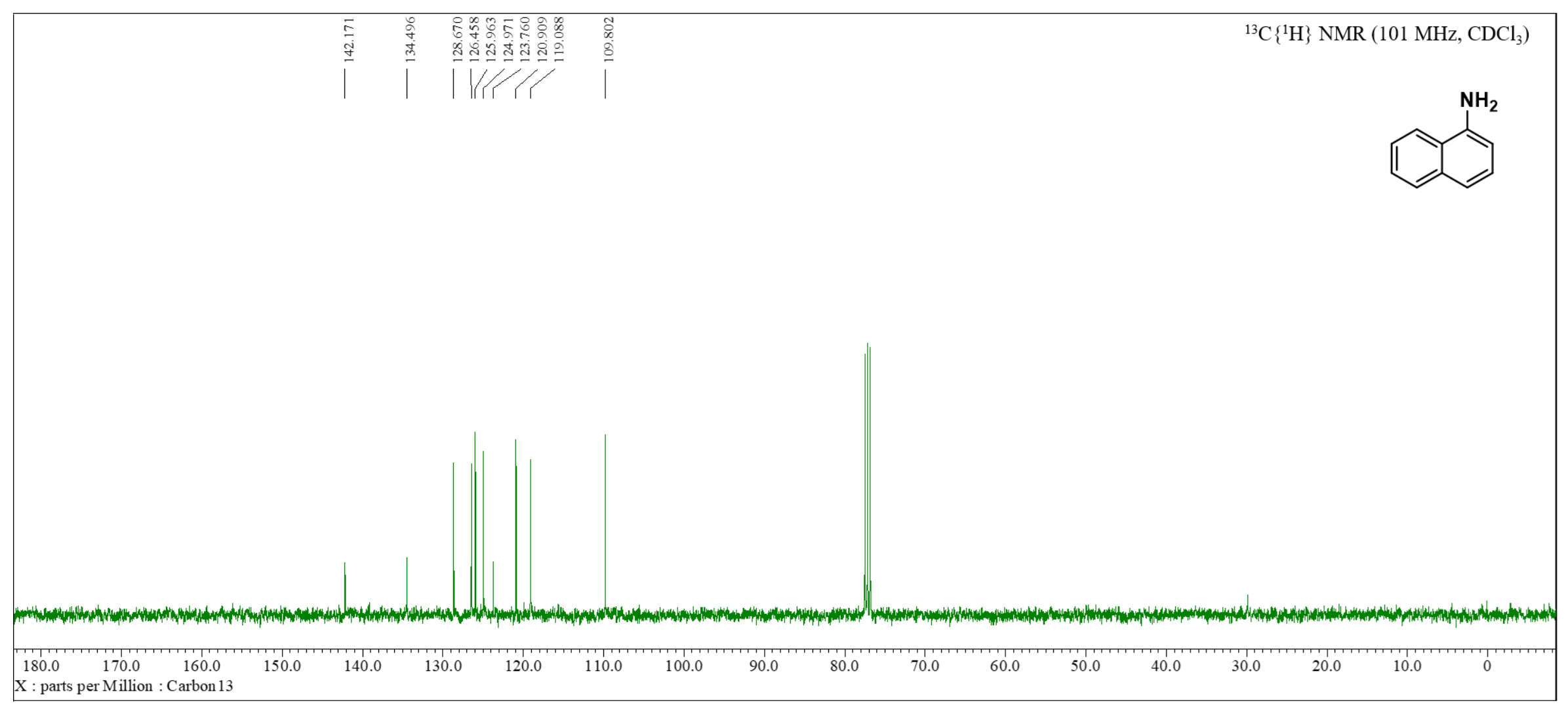

Figure S45. ${ }^{13} \mathrm{C}\left\{{ }^{1} \mathrm{H}\right\}$ NMR of $\mathbf{2} \mathbf{u}$ in $\mathrm{CDCl}_{3}$. 


$$
\angle C^{\circ}
$$




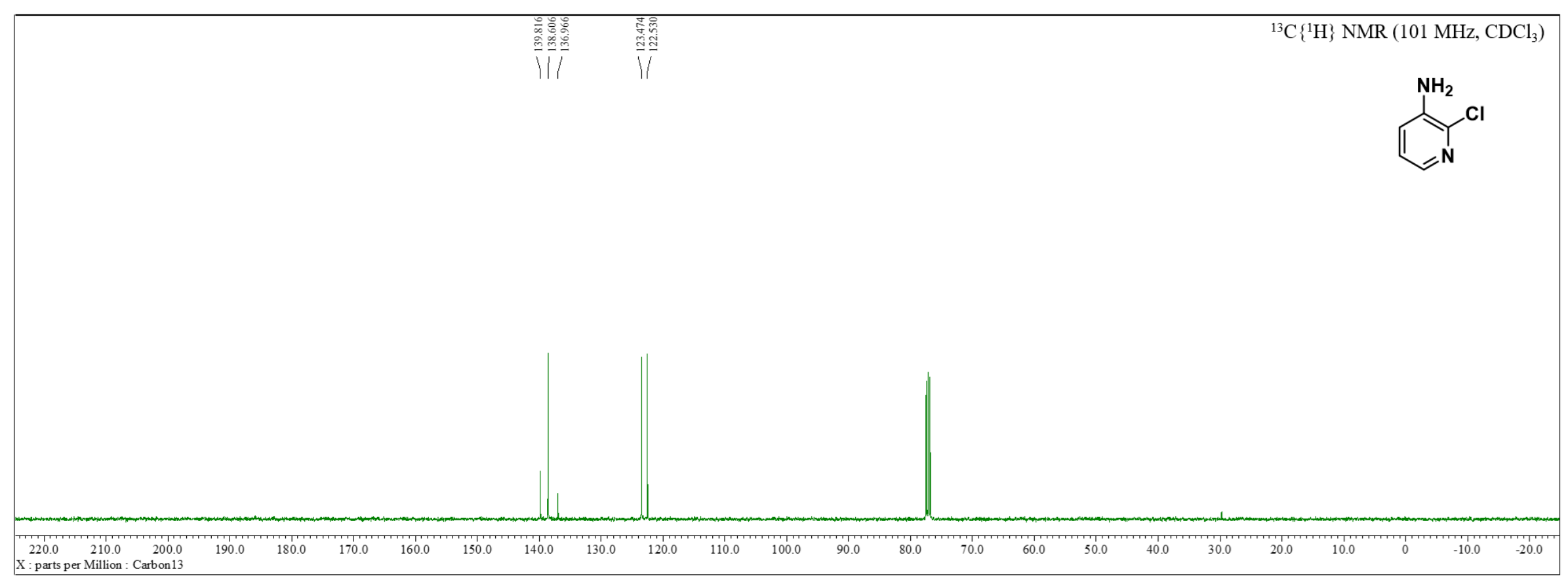

Figure S47. ${ }^{13} \mathrm{C}\left\{{ }^{1} \mathrm{H}\right\}$ NMR of $\mathbf{2 v}$ in $\mathrm{CDCl}_{3}$. 


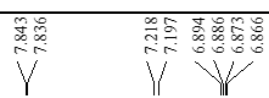

$\prod^{\overline{\mathrm{s}}}$

${ }^{1} \mathrm{H}$ NMR (400 MHz, $\mathrm{CDCl}_{3}$ )<smiles>Nc1ccc(Br)nc1</smiles>

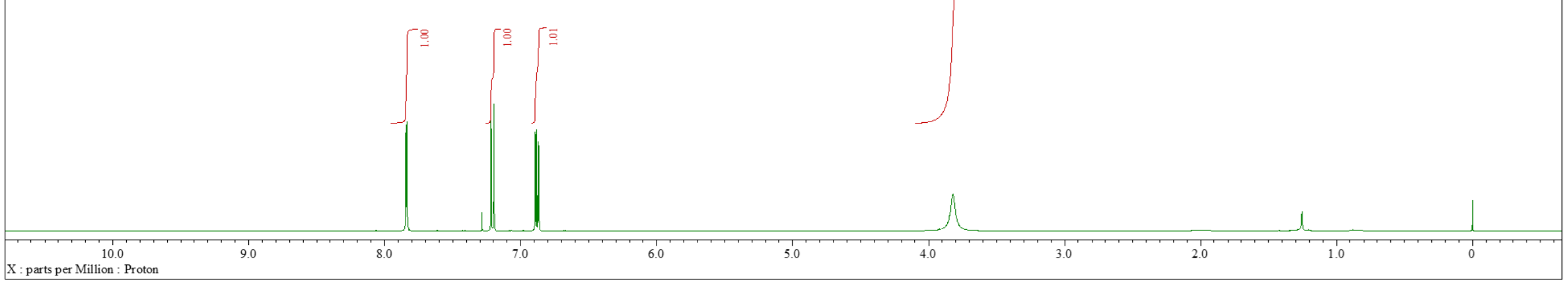

Figure S48. ${ }^{1} \mathrm{H}$ NMR of $\mathbf{2 w}$ in $\mathrm{CDCl}_{3}$.

S52 


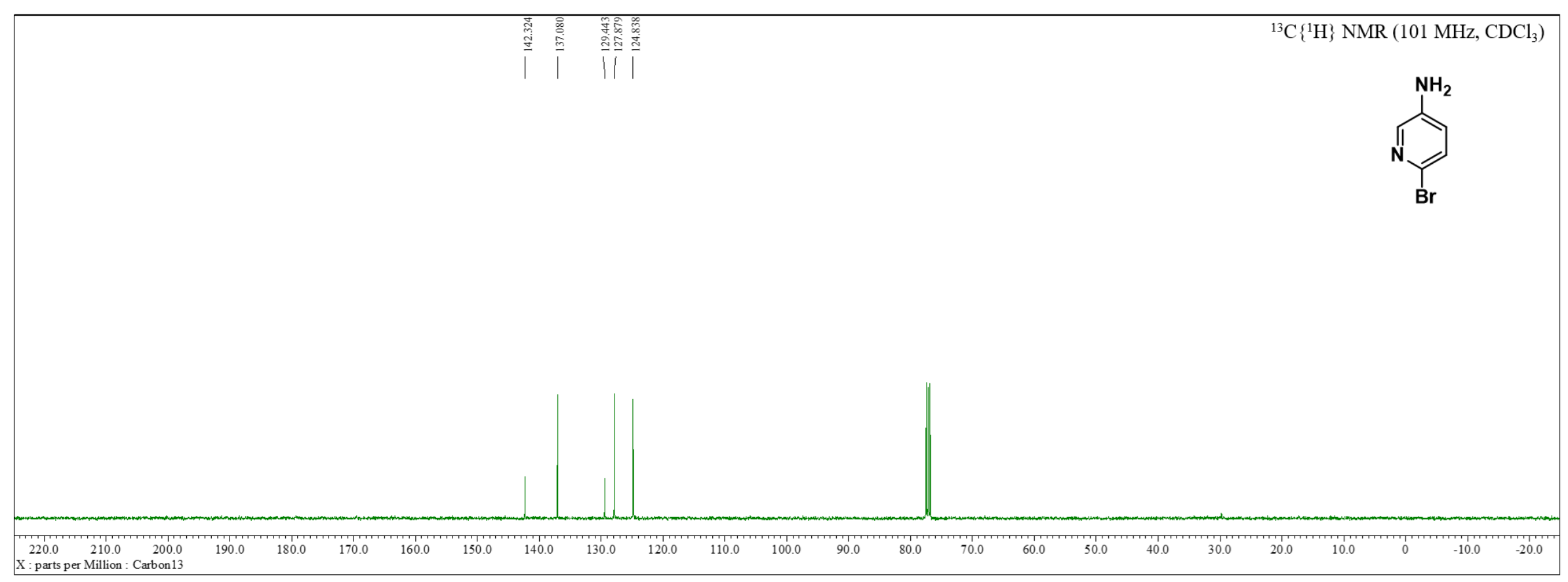

Figure S49. ${ }^{13} \mathrm{C}\left\{{ }^{1} \mathrm{H}\right\}$ NMR of $\mathbf{2} \mathbf{w}$ in $\mathrm{CDCl}_{3}$. 


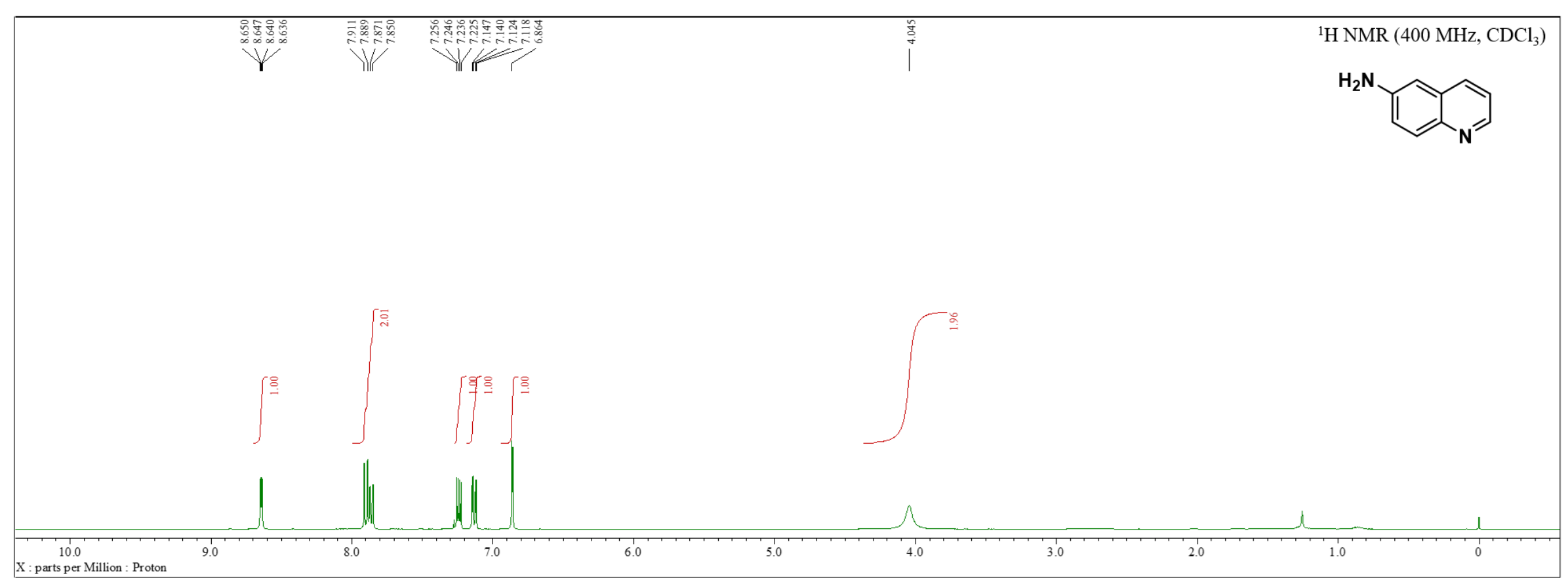

Figure S50. ${ }^{1} \mathrm{H} \mathrm{NMR}$ of $\mathbf{2 x}$ in $\mathrm{CDCl}_{3}$ 


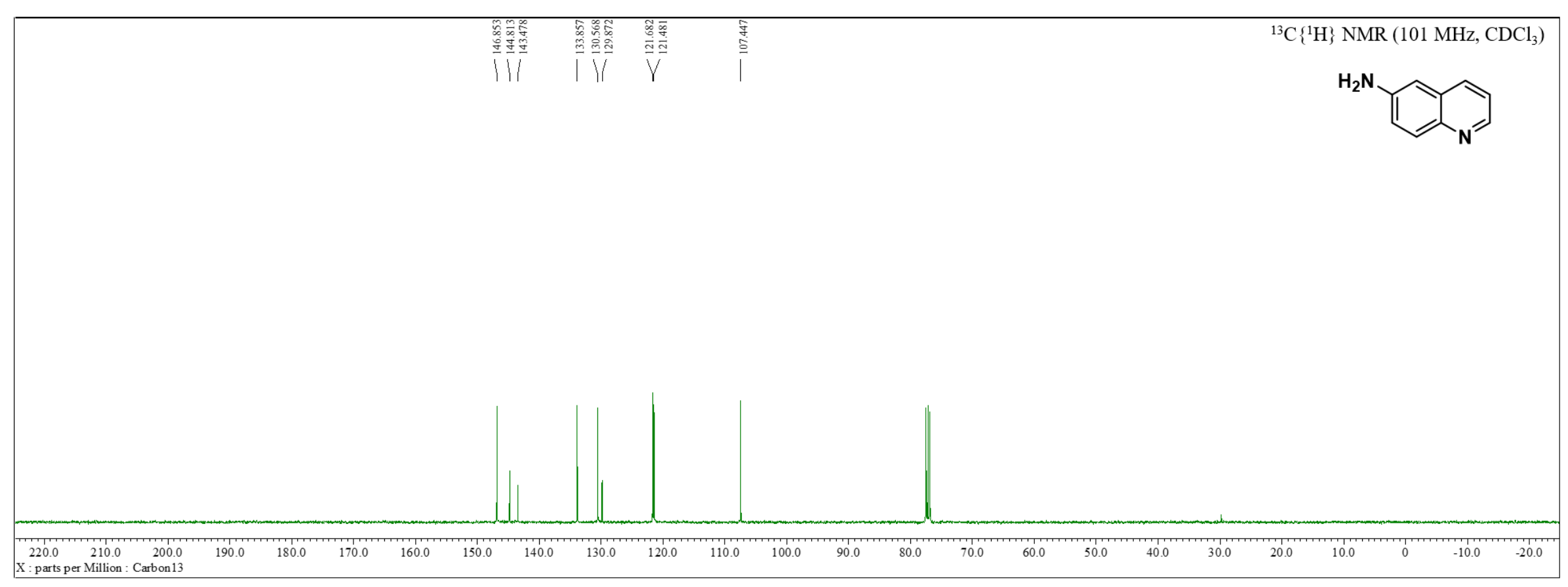

Figure S51. ${ }^{13} \mathrm{C}\left\{{ }^{1} \mathrm{H}\right\}$ NMR of $\mathbf{2 x}$ in $\mathrm{CDCl}_{3}$. 


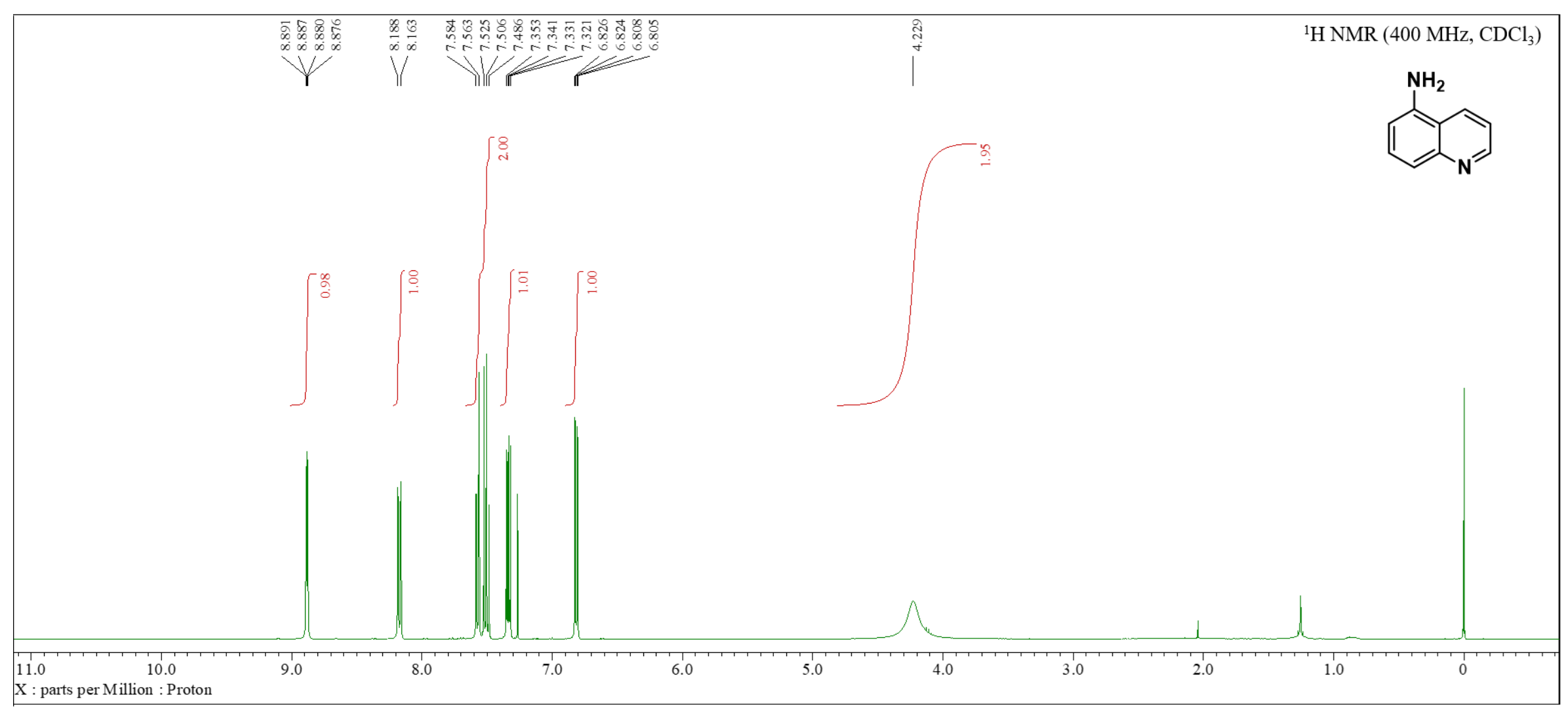

Figure S52. ${ }^{1} \mathrm{H}$ NMR of $\mathbf{2 y}$ in $\mathrm{CDCl}_{3}$. 


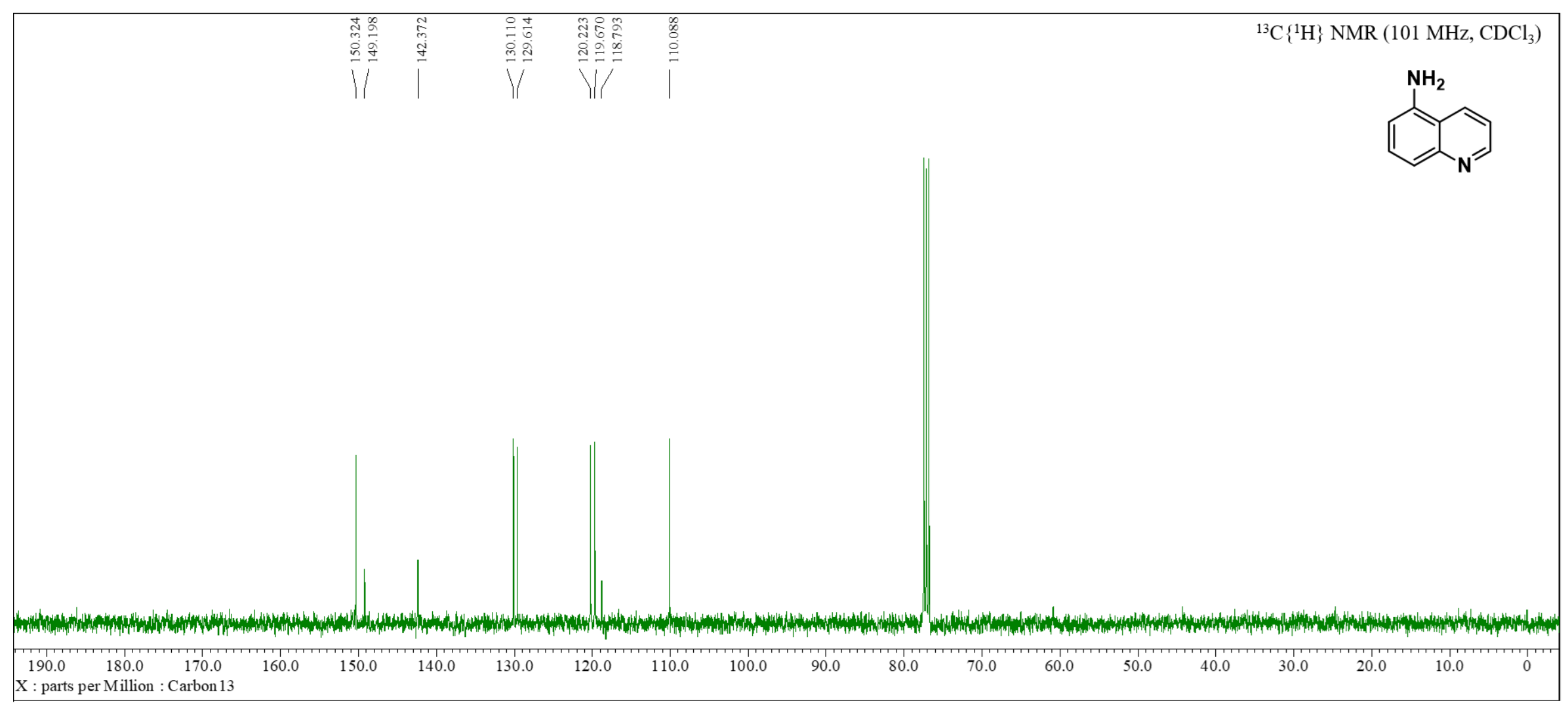

Figure S53. ${ }^{13} \mathrm{C}\left\{{ }^{1} \mathrm{H}\right\} \mathrm{NMR}$ of $\mathbf{2 y}$ in $\mathrm{CDCl}_{3}$. 


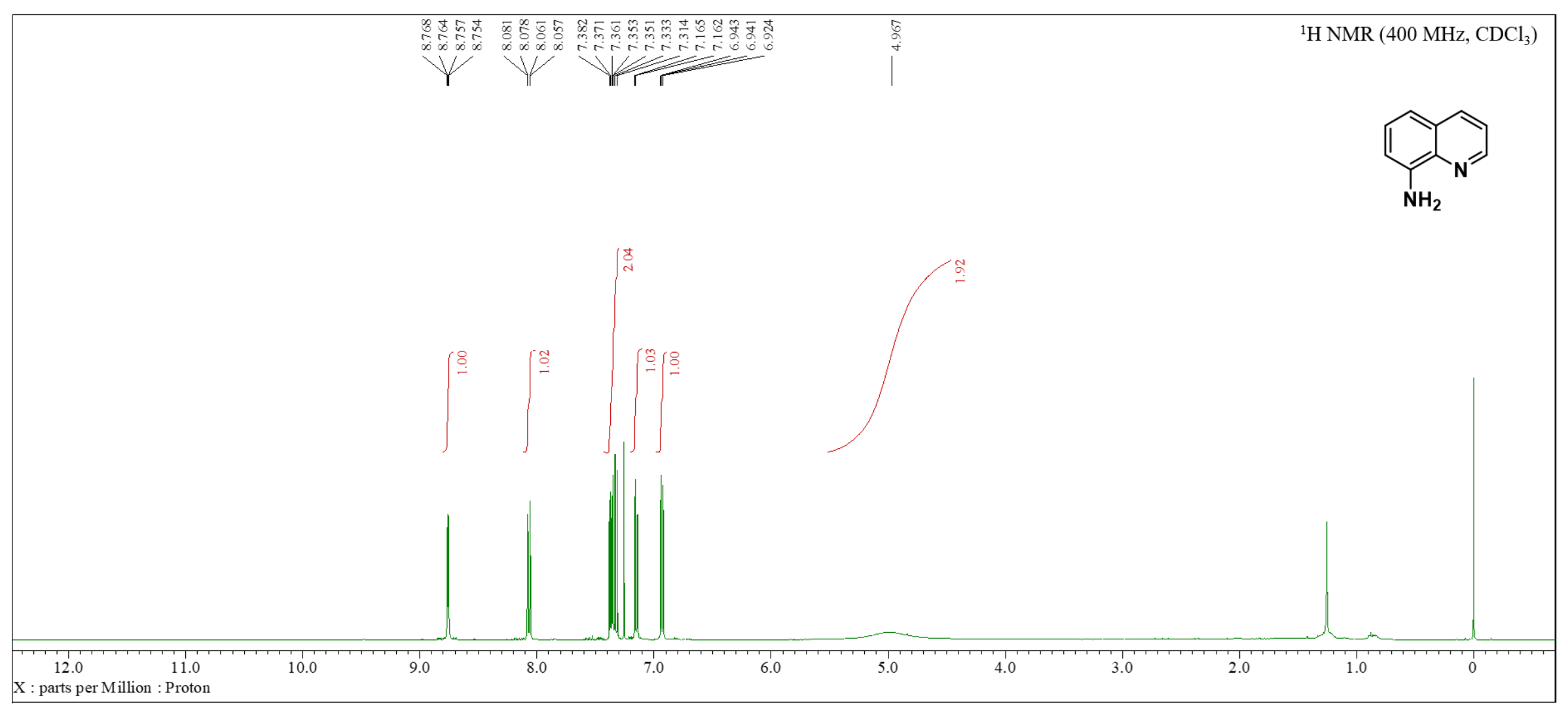

Figure S54. ${ }^{1} \mathrm{H} \mathrm{NMR}$ of $\mathbf{2 z}$ in $\mathrm{CDCl}_{3}$. 


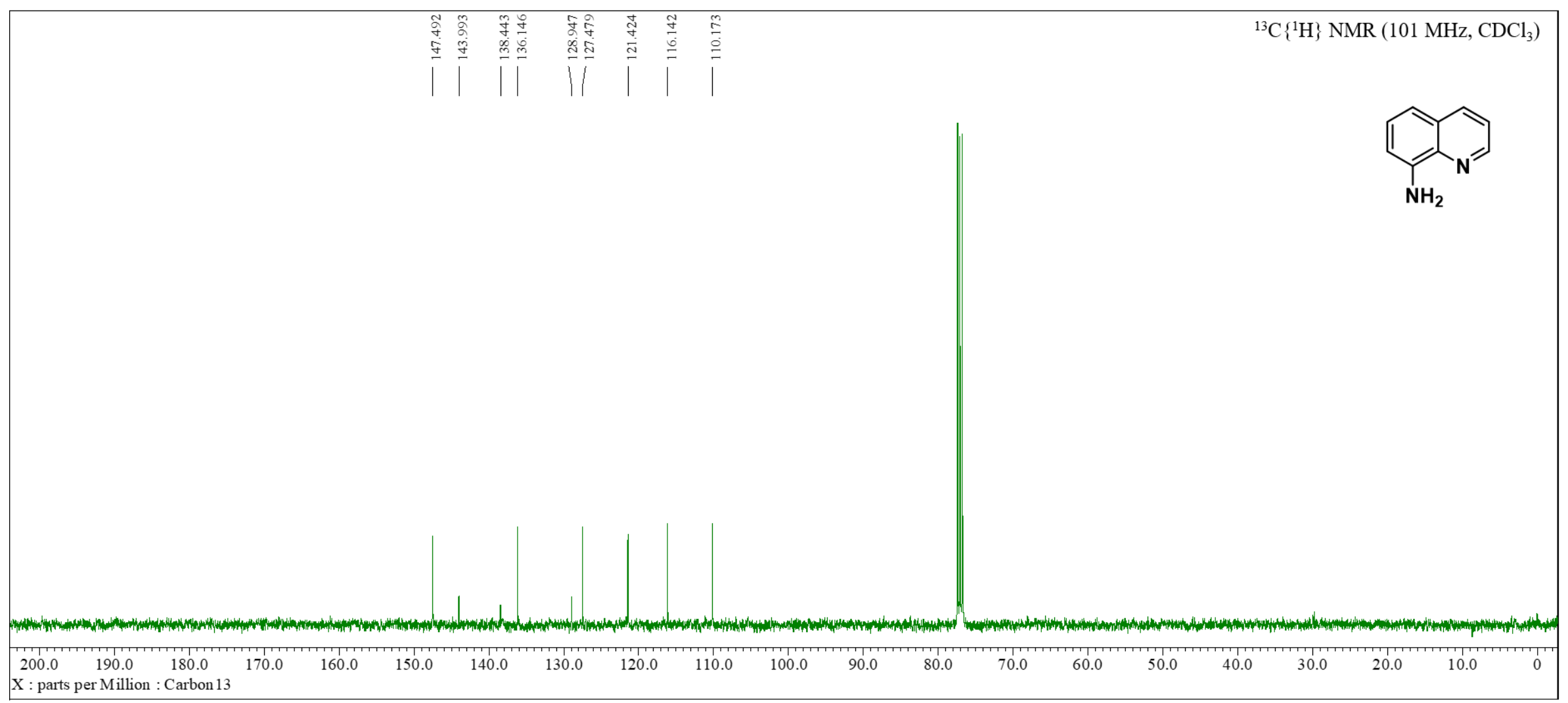

Figure S55. ${ }^{13} \mathrm{C}\left\{{ }^{1} \mathrm{H}\right\}$ NMR of $\mathbf{2 z}$ in $\mathrm{CDCl}_{3}$. 


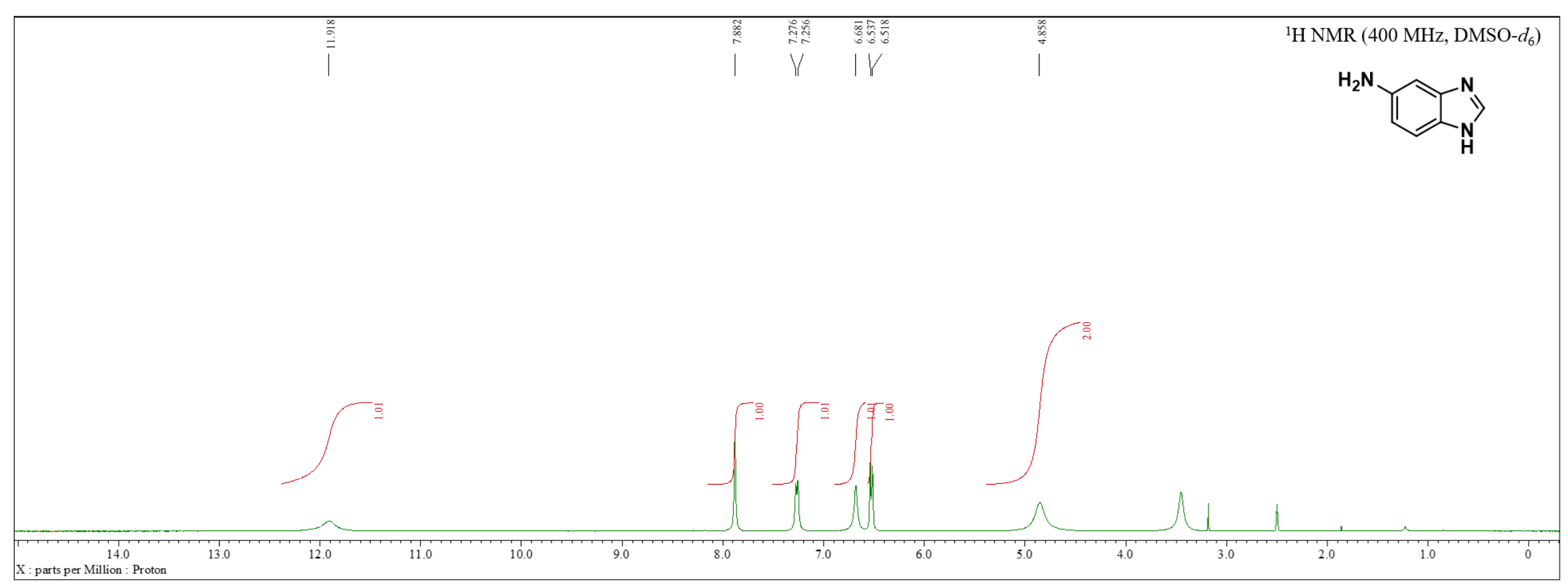

Figure S56. ${ }^{1} \mathrm{H}$ NMR of $\mathbf{2 a a}$ in DMSO- $d_{6}$. 


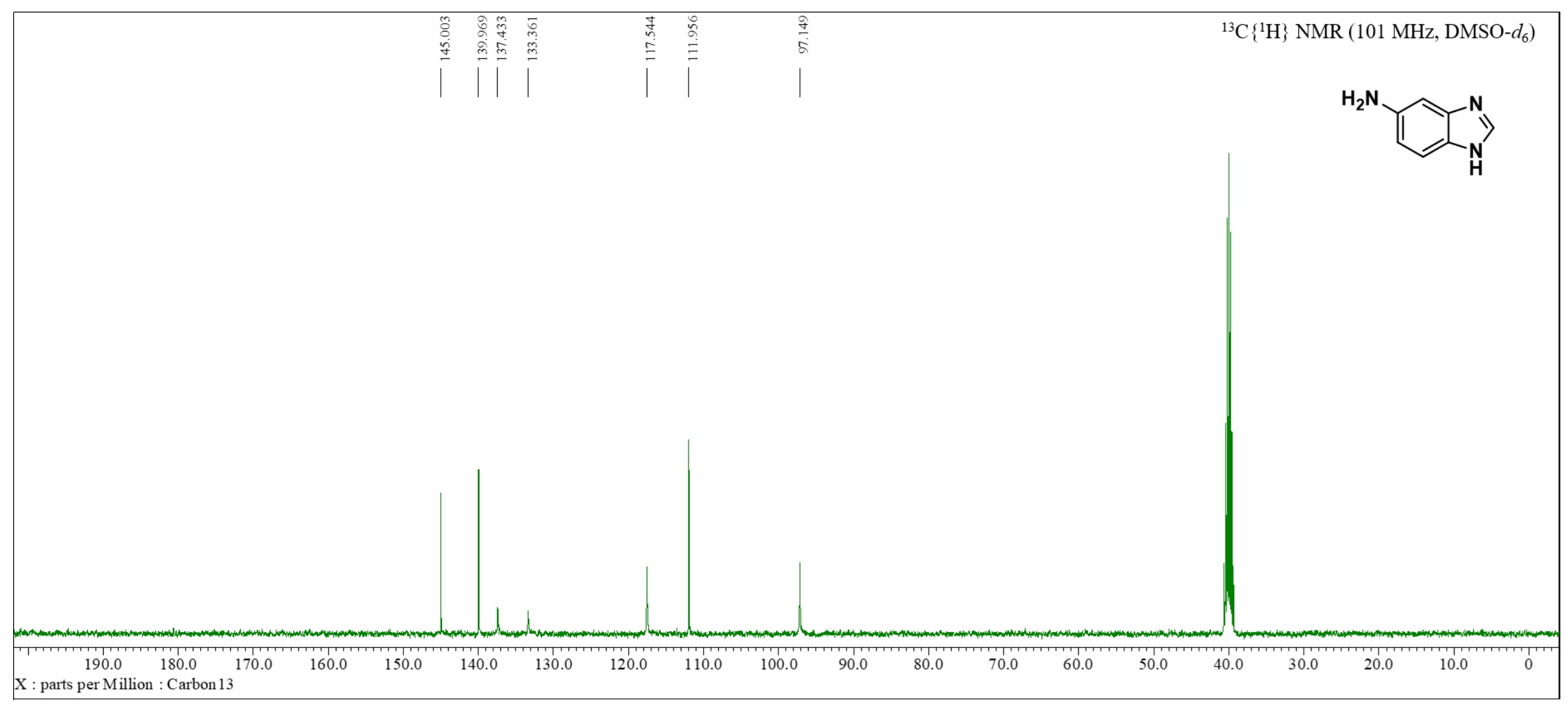

Figure S57. ${ }^{13} \mathrm{C}\left\{{ }^{1} \mathrm{H}\right\}$ NMR of $\mathbf{2} \mathbf{a a}$ in DMSO- $d_{6}$ 


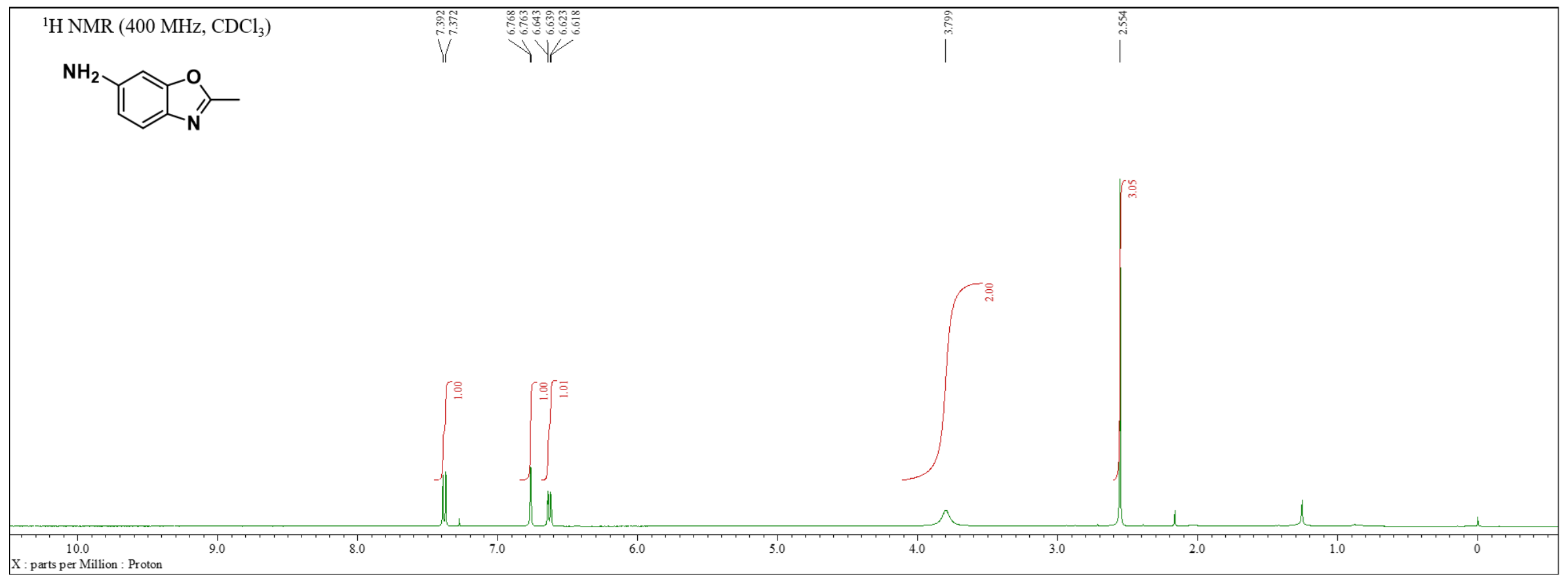

Figure S58. ${ }^{1} \mathrm{H} \mathrm{NMR}$ of $\mathbf{2} \mathbf{a b}$ in $\mathrm{CDCl}_{3}$.

S62 


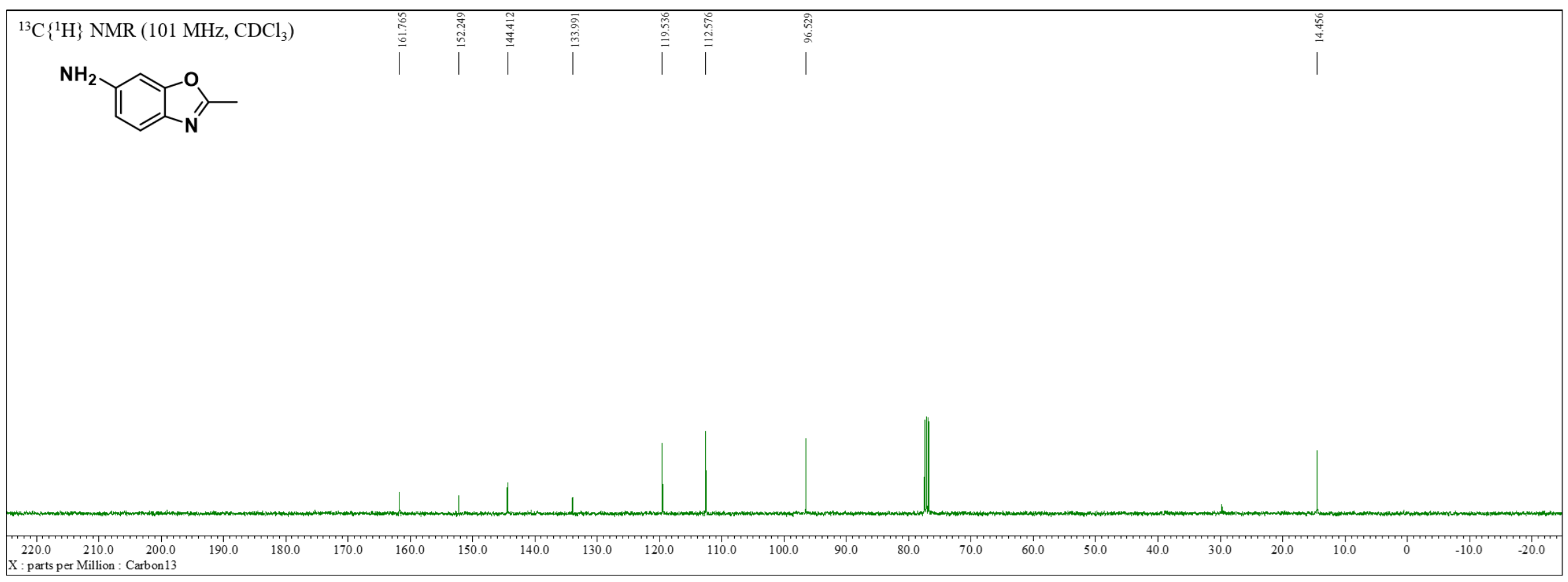

Figure S59. ${ }^{13} \mathrm{C}\left\{{ }^{1} \mathrm{H}\right\}$ NMR of $\mathbf{2} \mathbf{a b}$ in $\mathrm{CDCl}_{3}$.

S63 


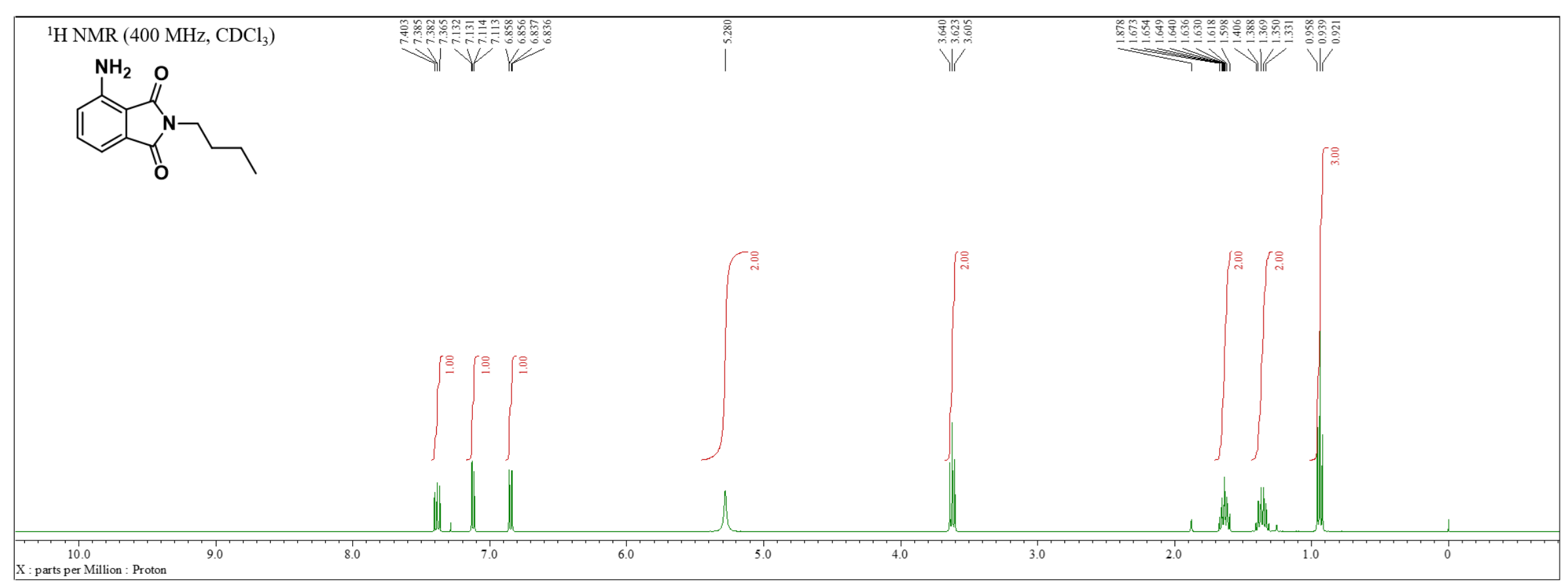

Figure S60. ${ }^{1} \mathrm{H}$ NMR of 2 ac in $\mathrm{CDCl}_{3}$. 


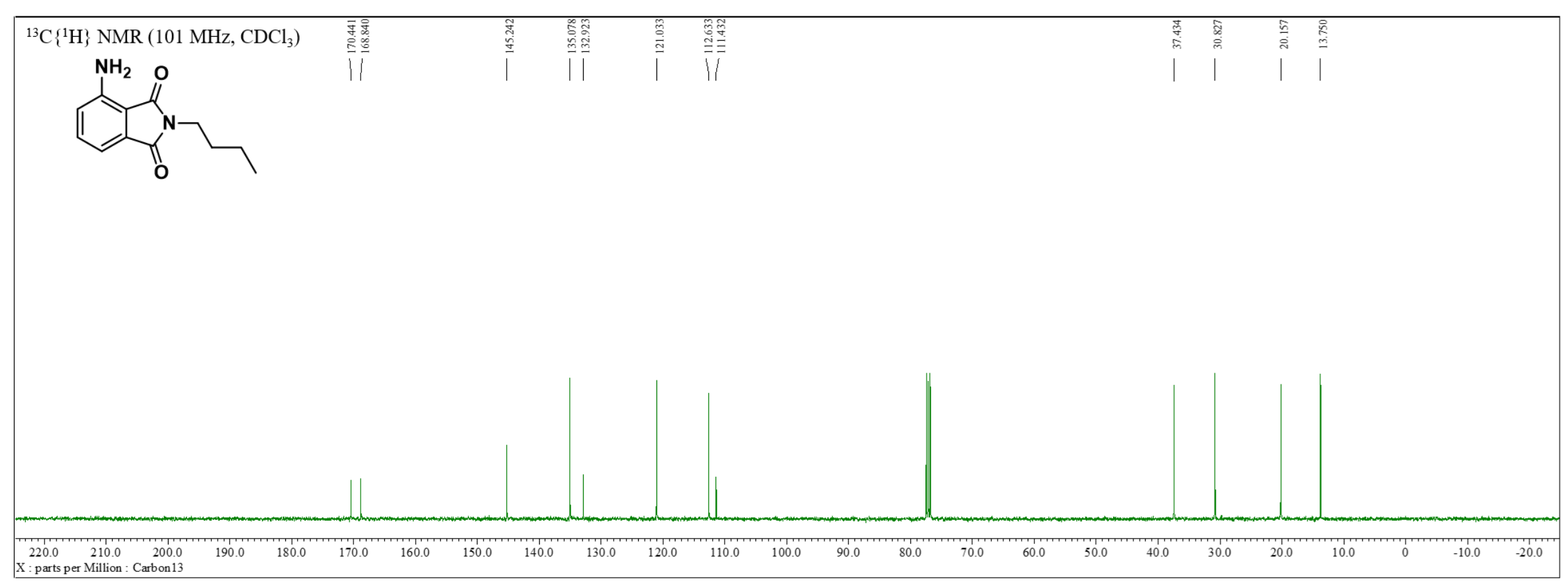

Figure S61. ${ }^{13} \mathrm{C}\left\{{ }^{1} \mathrm{H}\right\}$ NMR of $\mathbf{2 a c}$ in $\mathrm{CDCl}_{3}$. 


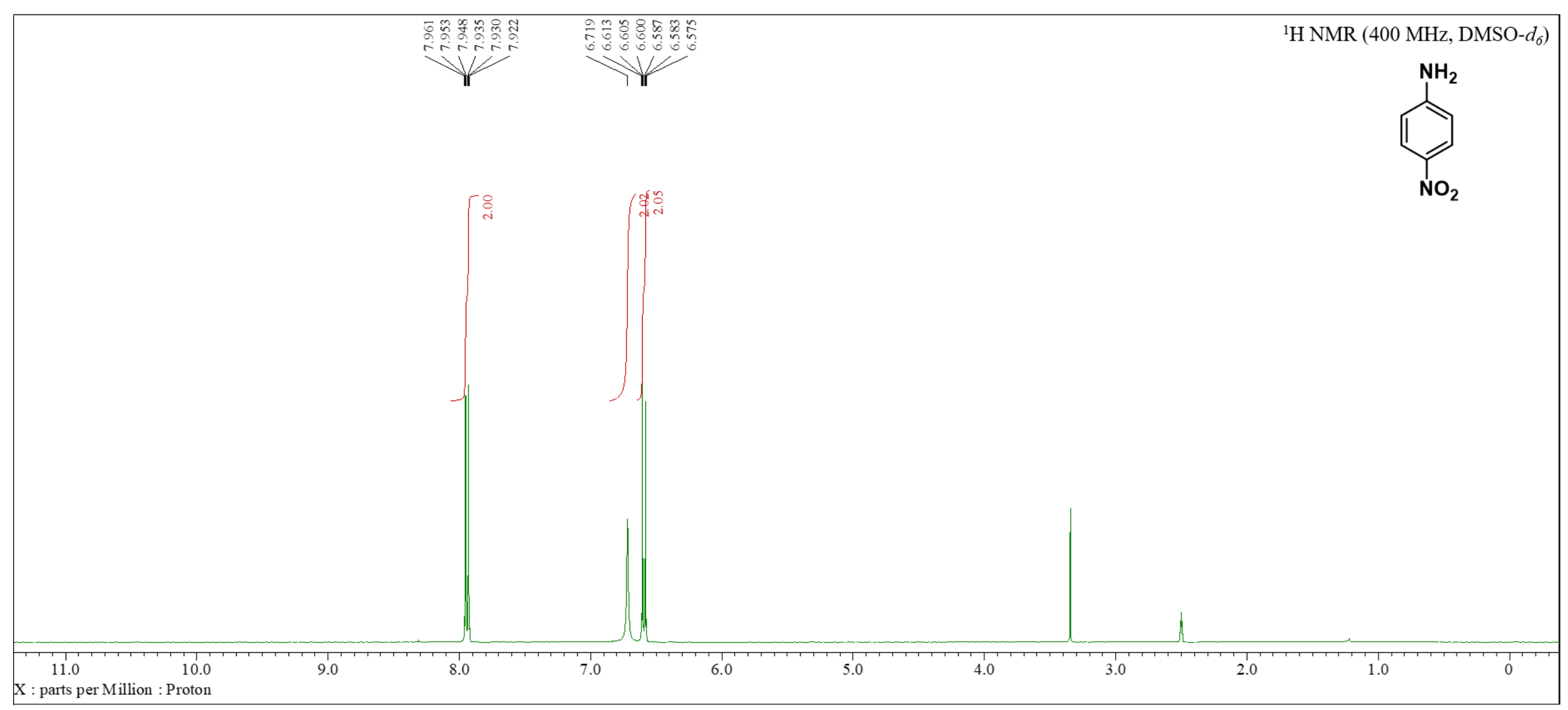

Figure S62. ${ }^{1} \mathrm{H}$ NR of $\mathbf{2 a d}$ in DMSO- $d_{6}$. 


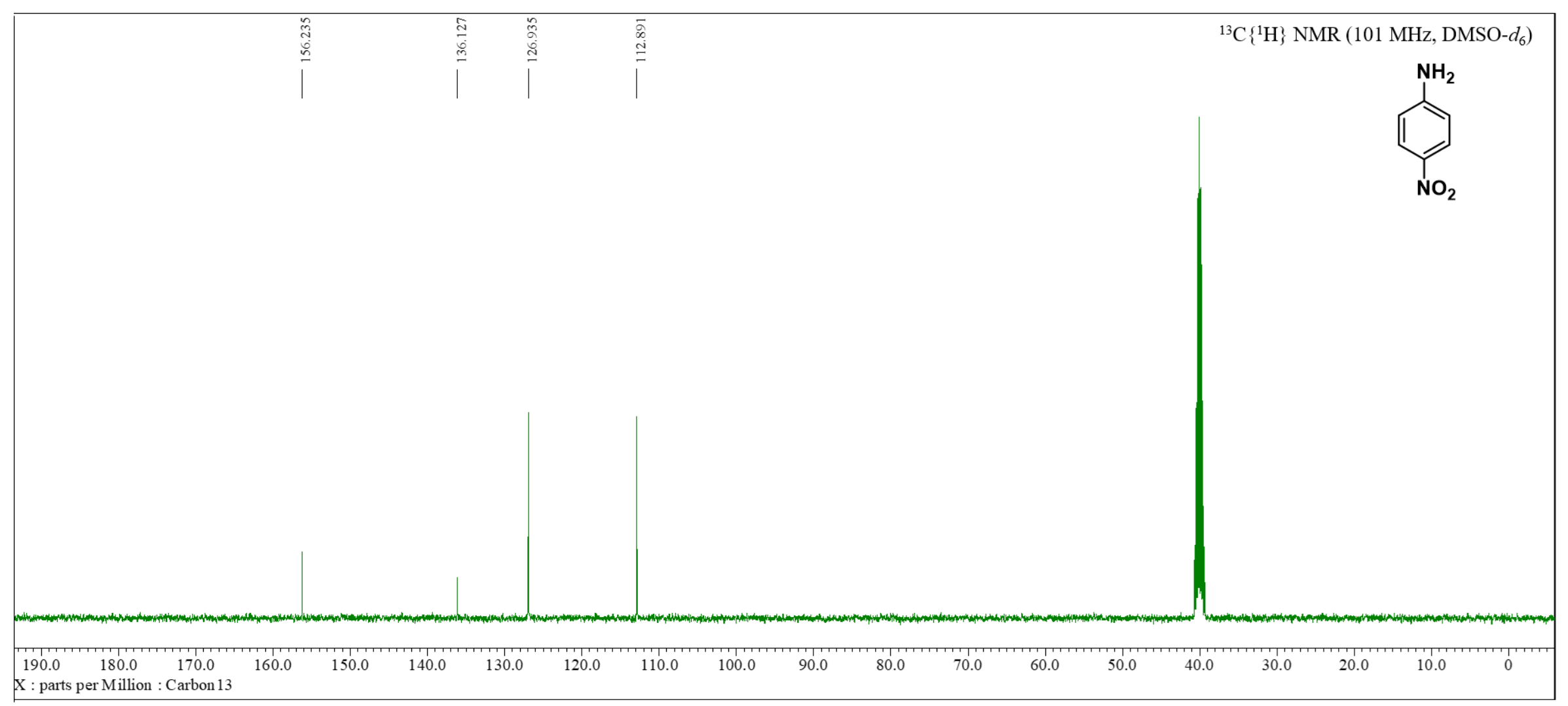

Figure S63. ${ }^{13} \mathrm{C}\left\{{ }^{1} \mathrm{H}\right\}$ NMR of $\mathbf{2} \mathbf{a d}$ in DMSO- $d_{6}$. 


$$
=17
$$




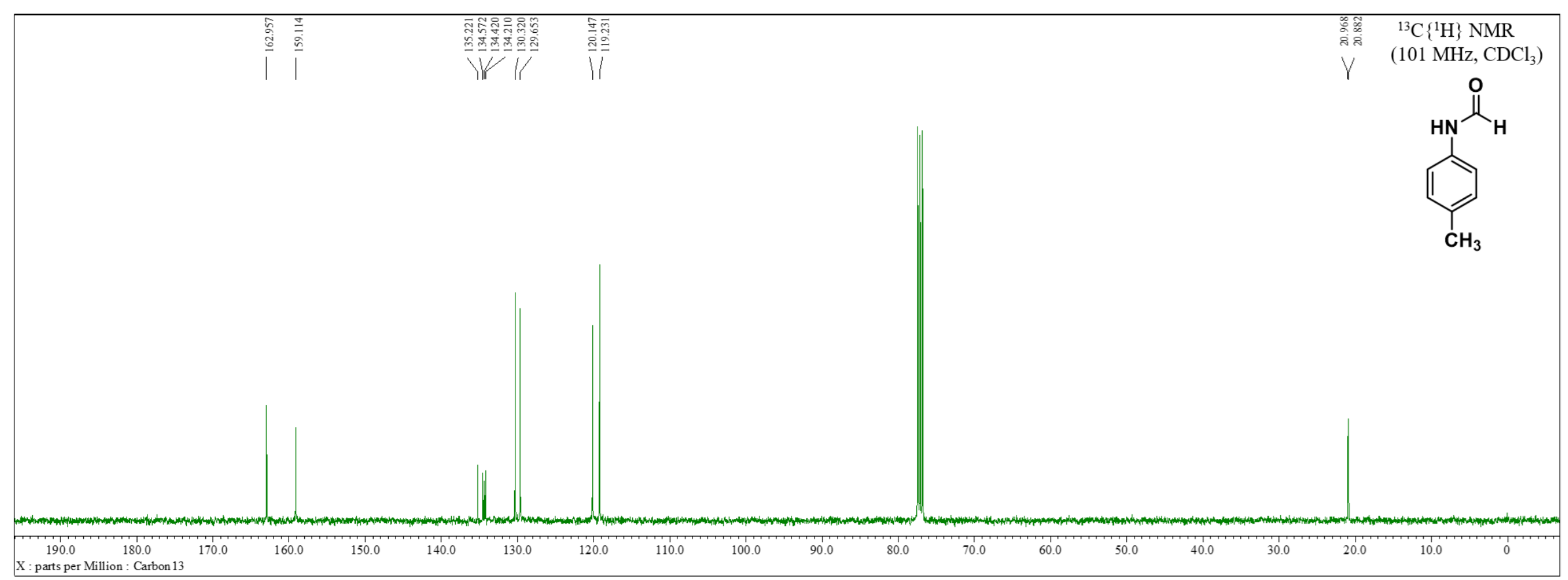

Figure S65. ${ }^{13} \mathrm{C}\left\{{ }^{1} \mathrm{H}\right\}$ NMR of $\mathbf{3 a g}$ in $\mathrm{CDCl}_{3}$ 


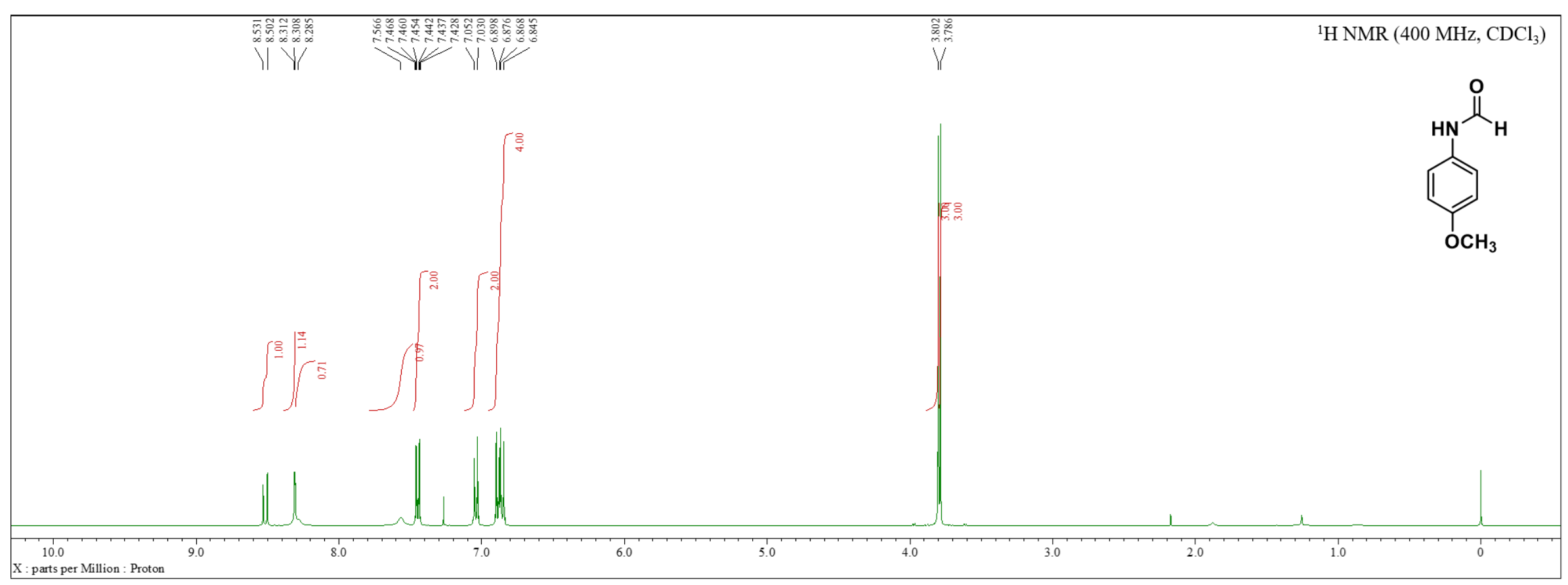

Figure S66. ${ }^{1} \mathrm{H}$ NMR of $\mathbf{3 a h}$ in $\mathrm{CDCl}_{3}$. 


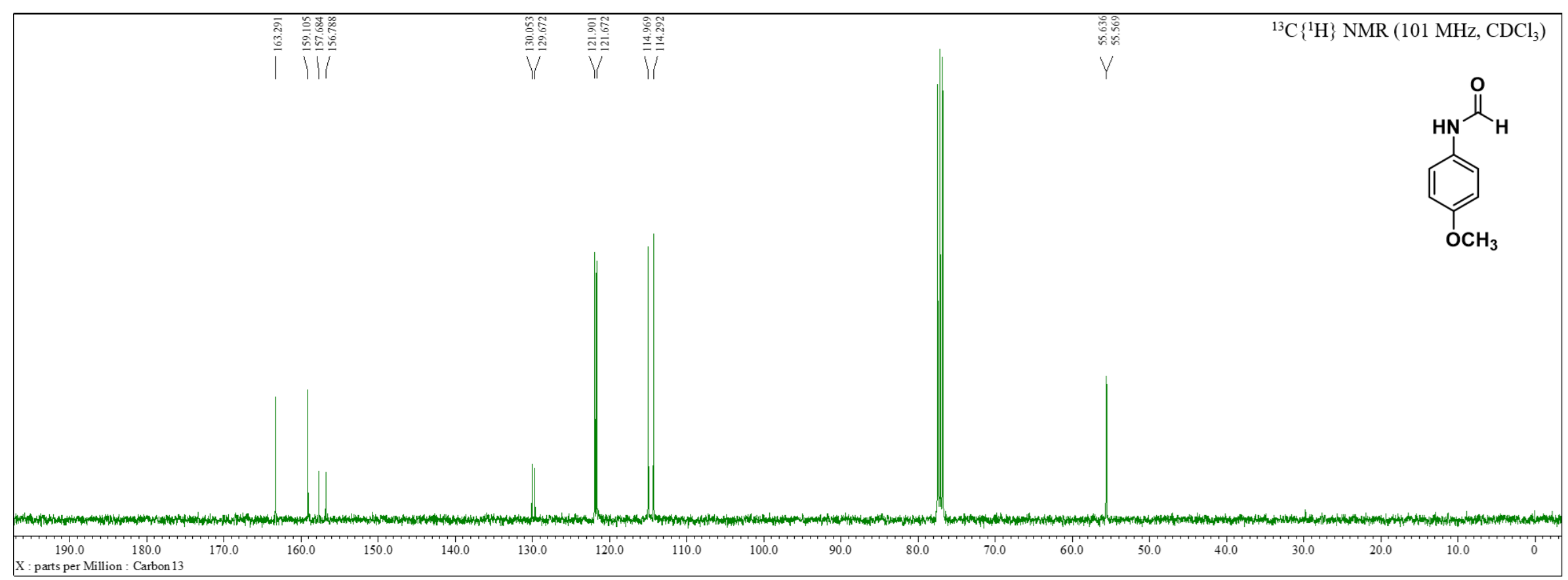

Figure S67. ${ }^{13} \mathrm{C}\left\{{ }^{1} \mathrm{H}\right\}$ NMR of $\mathbf{3 a h}$ in $\mathrm{CDCl}_{3}$ 


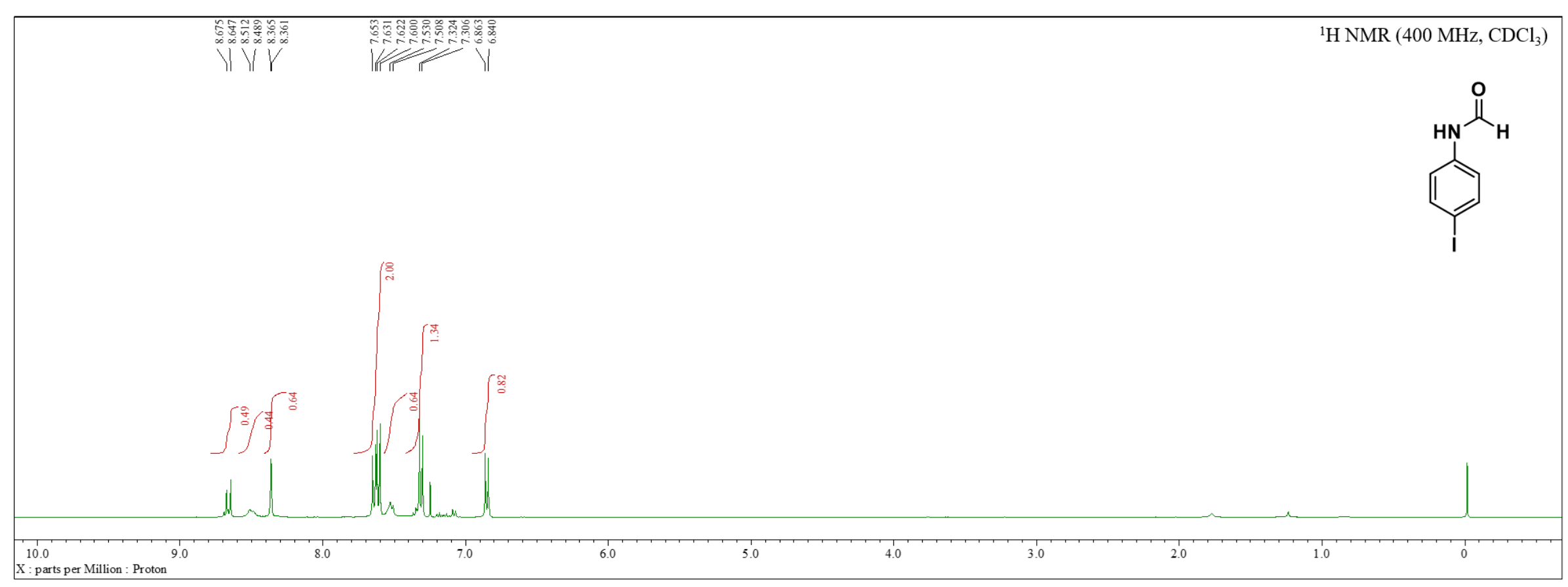

Figure $\mathbf{S 6 8} .{ }^{1} \mathrm{H} \mathrm{NMR}$ of $\mathbf{3 f}$ in $\mathrm{CDCl}_{3}$. 


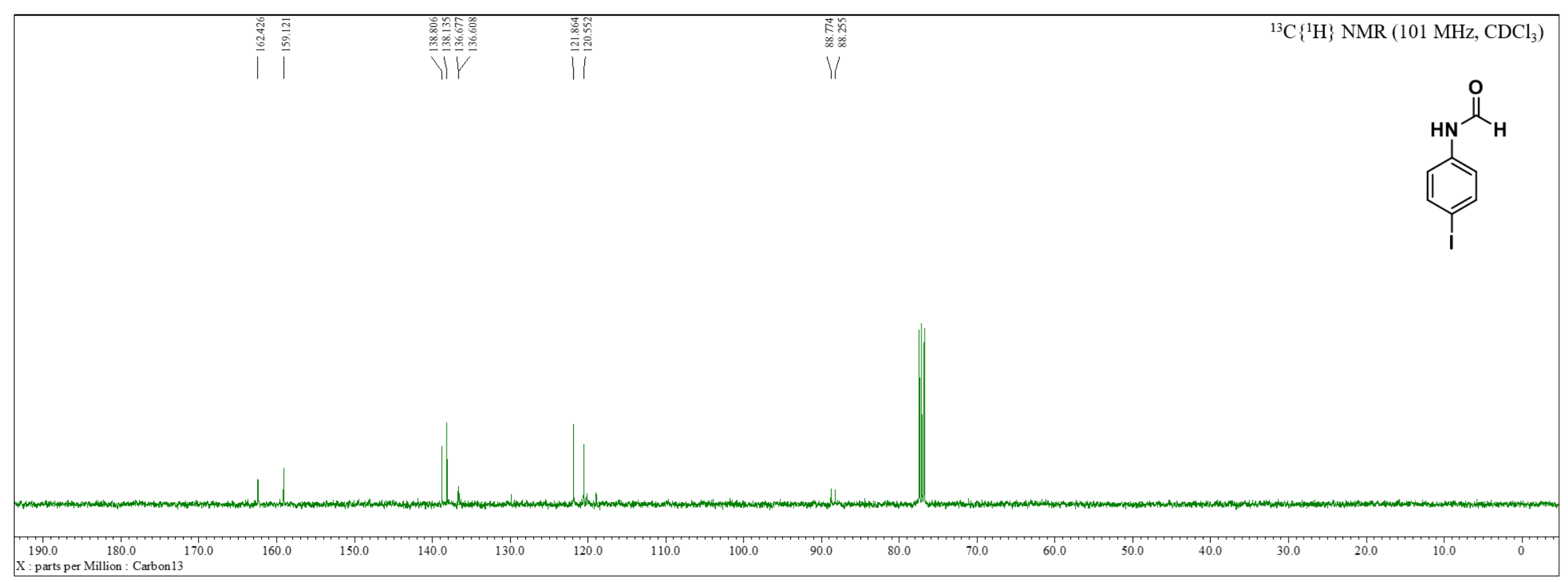

Figure S69. ${ }^{13} \mathrm{C}\left\{{ }^{1} \mathrm{H}\right\}$ NMR of $\mathbf{3 f}$ in $\mathrm{CDCl}_{3}$. 


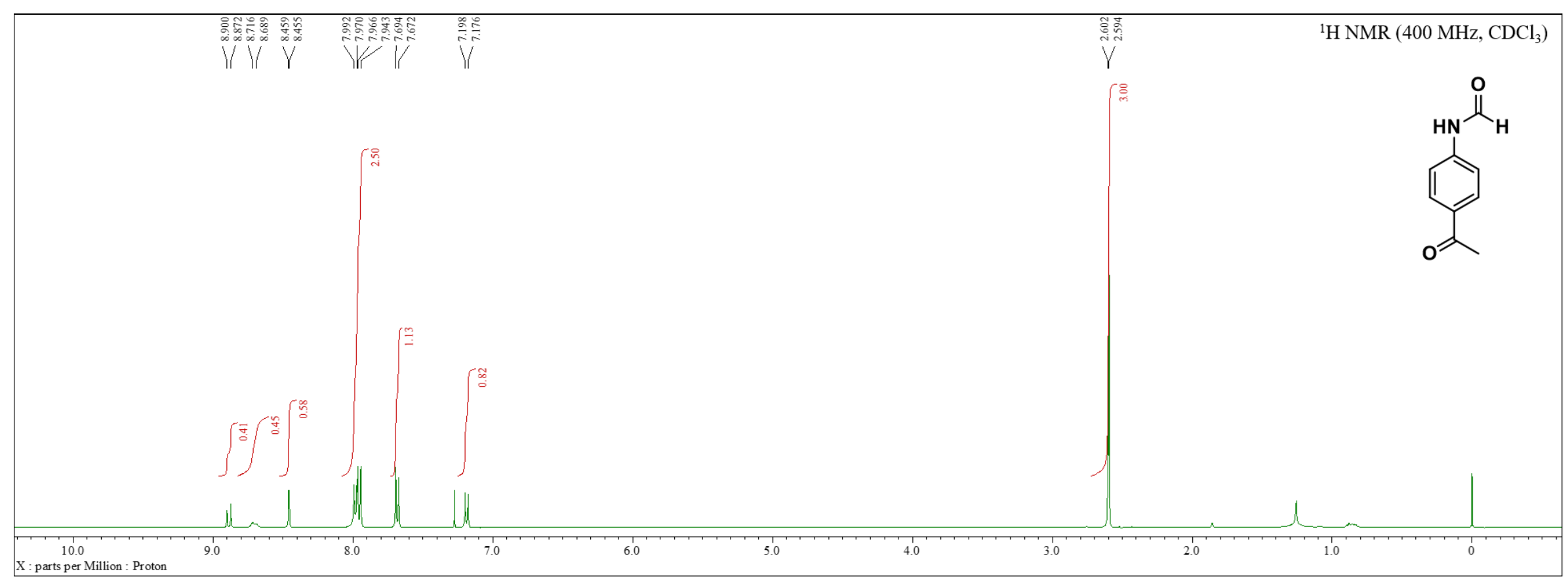

Figure S70. ${ }^{1} \mathrm{H} \mathrm{NMR}$ of $\mathbf{3 n}$ in $\mathrm{CDCl}_{3}$ 


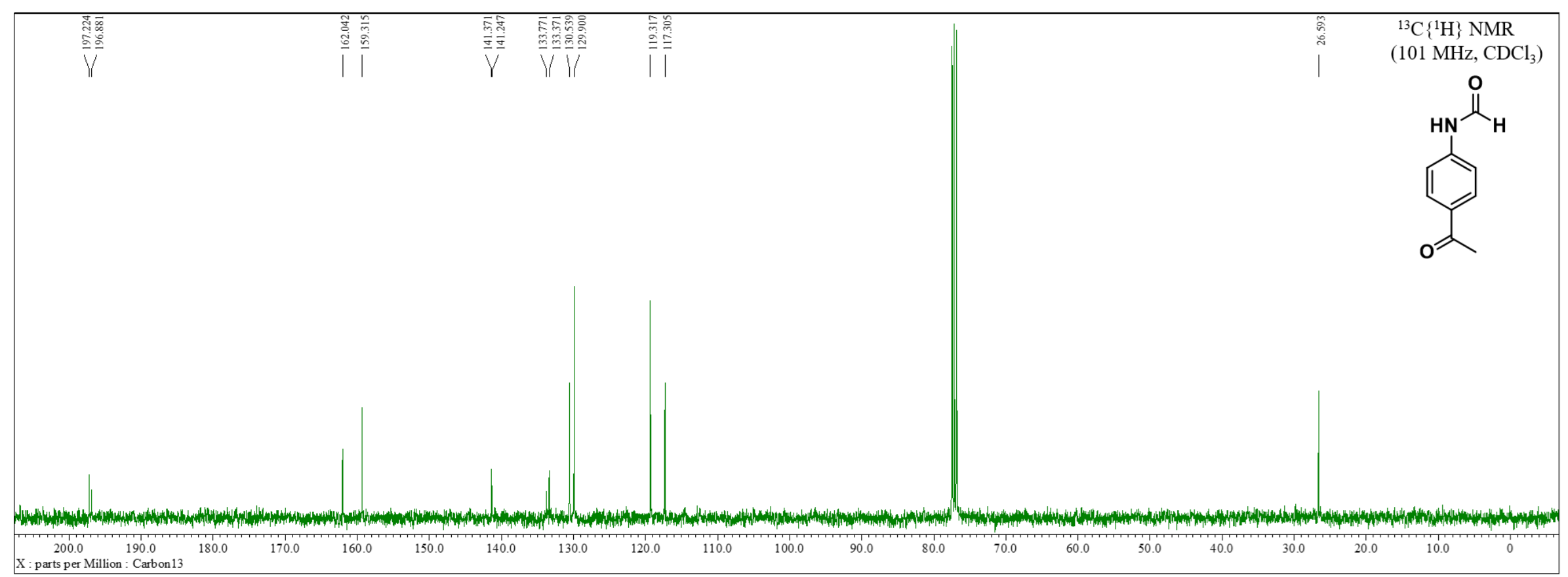

Figure S71. ${ }^{13} \mathrm{C}\left\{{ }^{1} \mathrm{H}\right\}$ NMR of $\mathbf{3 n}$ in $\mathrm{CDCl}_{3}$ 


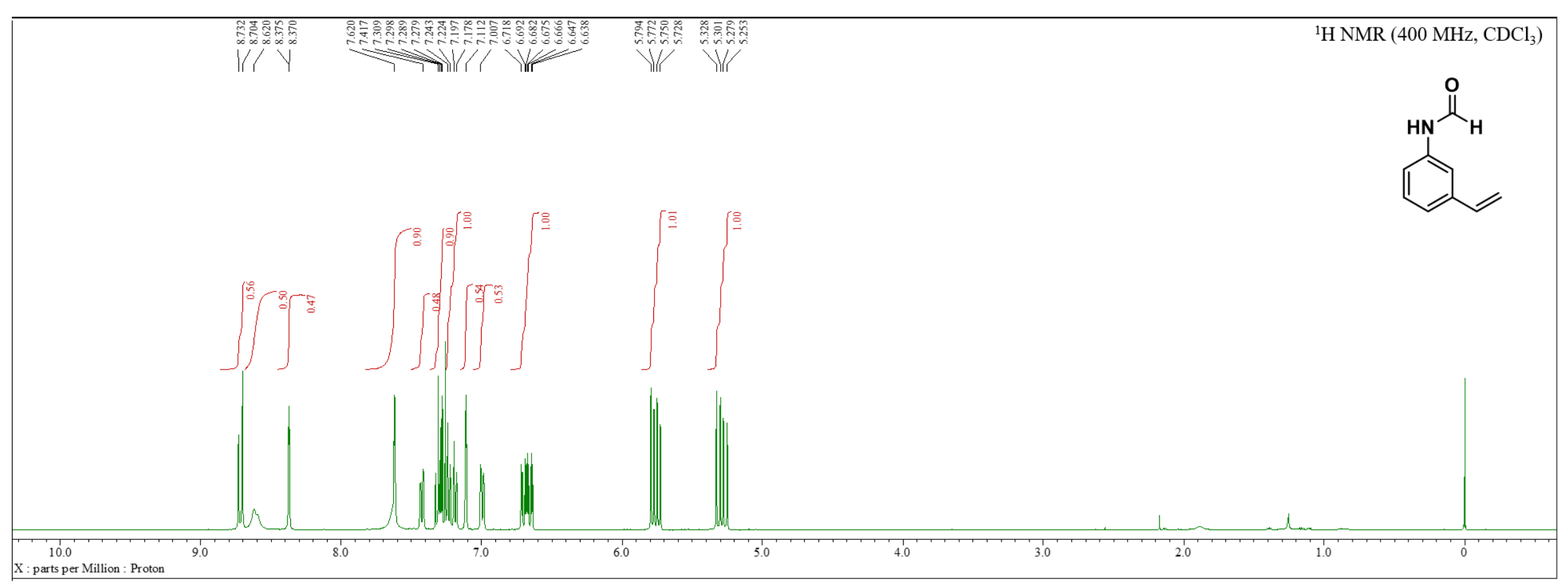

Figure $\mathbf{S 7 2} .{ }^{1} \mathrm{H} \mathrm{NMR}$ of $\mathbf{3 a}$ in $\mathrm{CDCl}_{3}$. 


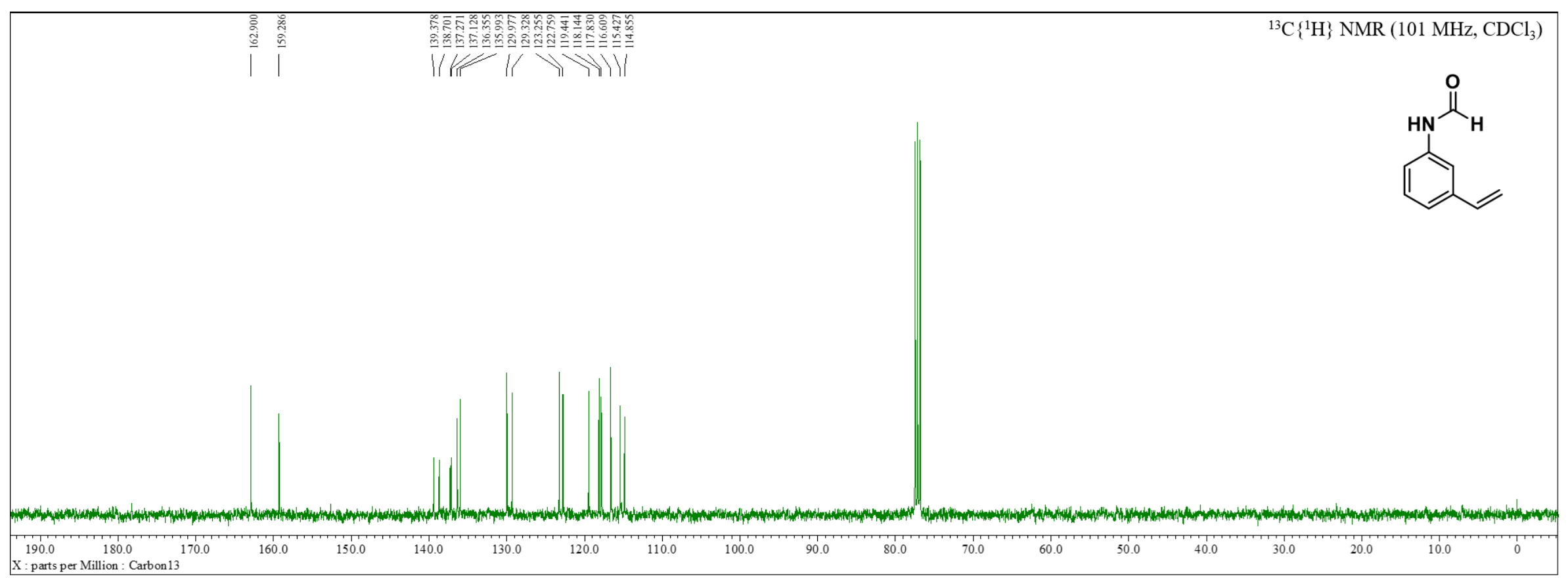

Figure S73. ${ }^{13} \mathrm{C}\left\{{ }^{1} \mathrm{H}\right\}$ NMR of $\mathbf{3 a}$ in $\mathrm{CDCl}_{3}$. 


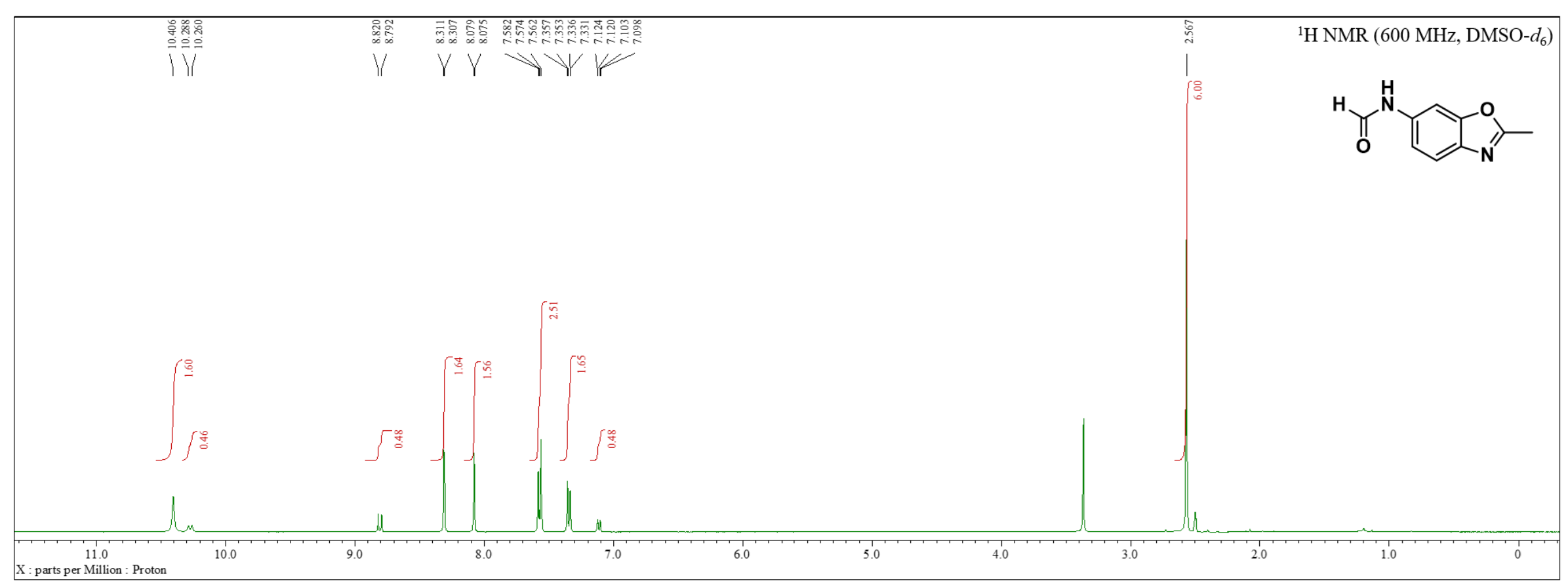

Figure S74. ${ }^{1} \mathrm{H}$ NMR of 3ab in DMSO- $d_{6}$. 


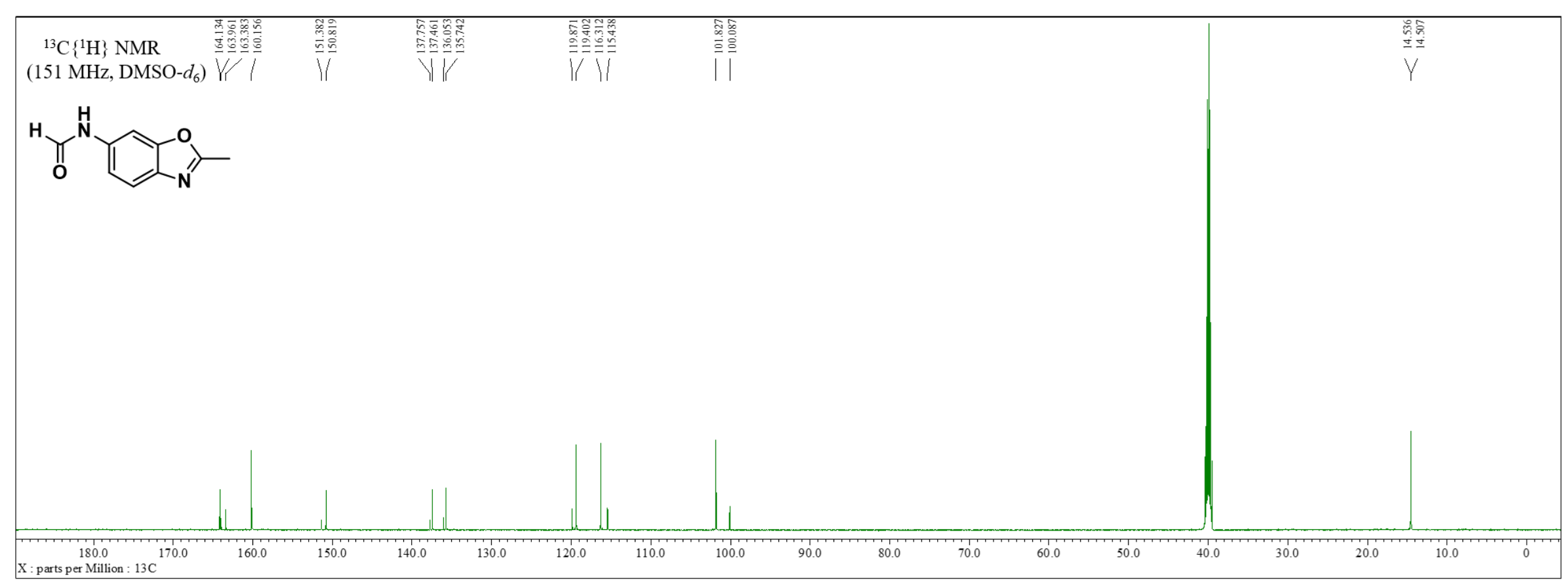

Figure S75. ${ }^{13} \mathrm{C}\left\{{ }^{1} \mathrm{H}\right\}$ NMR of 3ab in DMSO- $d_{6}$. 